\title{
Borderline Disorder: (De facto) Historical Ethnic Borders and Contemporary Conflict in Africa*
}

\author{
Emilio Depetris-Chauvin ${ }^{\dagger}$ r and Ömer Özak ${ }^{\ddagger}$
}

\begin{abstract}
We explore the effect of historical ethnic borders on contemporary conflict in Africa. We document that both the intensive and extensive margins of contemporary conflict are higher close to historical ethnic borders. Exploiting variations across artificial regions within an ethnicity's historical homeland and a theory-based instrumental variable approach, we find that regions crossed by historical ethnic borders have 27 percentage points higher probability of conflict and 7.9 percentage points higher probability of being the initial location of a conflict. We uncover several key underlying mechanisms: competition for agricultural land, population pressure, cultural similarity, and weak property rights.
\end{abstract}

Keywords: Borders, Conflict, Territory, Property Rights, Landownership, Population Pressure, Migration, Historical Homelands, Development, Africa, Voronoi Tessellation, Thiessen Tessellation

JEL Classification: D74, N57, O13, O17, O43, P48, Q15, Q34

${ }^{*}$ We wish to thank James Fenske, Raphael Franck, Pauline Grosjean, Moshe Hazan, Federico Masera, Moti Michaeli, Nathan Nunn, Assaf Sarid, Yannay Spitzer, Leonard Wantchekon, and David Weil, as well as participants at STATA TX Empirical Microeconomics Conference, MIPP Workshop in Political Economy and Political Science, 6th OzClio Workshop at UNSW, WEIA Conference at Keio University, LSE - Stanford - Universidad de los Andes Long-Run Development in Latin America, EH-Clio Lab Conference at PUC Chile, the Deep-Rooted Factors in Comparative Development Conference, LACEA 2020, Quantitative History Webinar Series - Asia Global Institute, SECHI 2021, and seminar participants at Brown, Ben-Gurion, Diego Portales, ICESI, Haifa, Hebrew, LANE HOPE, SMU, Tel Aviv, UC Merced, Universidad Nacional de Colombia, Virtual Economic History Seminar, and Wilfred Laurier University for helpful comments. We also thank Mathias Thoening for sharing the Stata command that allows for spatial autocorrelation adjustment in an IV setting.

†Instituto de Economía, Pontificia Universidad Católica de Chile, Santiago de Chile. E-mail: edepetris@uc.cl. ORCID 0000-0002-4236-7869.

${ }^{\ddagger}$ Department of Economics, Southern Methodist University, IZA and GLO. PO Box 0496, Dallas, TX 75275-0496. E-mail: ozak@smu.edu. Tel: (214) 768-2755. Fax: (214) 768-1821. ORCID 0000-0001-6421-2801. 


\section{Introduction}

Conflicts are a major scourge in many regions of the world, generating immense suffering and loss of human life. Moreover, conflicts remain a significant obstacle to the development process, lowering the incentives to accumulate human and physical capital, affecting the efficiency in the allocation of public resources, and eroding institutions and social capital. The African case is especially notable, given the wide geographical prevalence of conflicts and the pervasiveness of different types of intra- and interstate conflicts in its recent history. Unsurprisingly, conflicts are considered a key factor holding back African economic development (Easterly and Levine, 1997). Many underlying drivers of conflict in Africa have been suggested and explored in the literature, especially the determinants of intra- and interstate conflicts. ${ }^{1}$ There is an overwhelming consensus that ethnic tensions are a key catalyst of intrastate conflicts (Horowitz et al., 1985). Also, the extensive literature in economics, political science, and international studies focused on the causes of interstate conflict has documented the pivotal role of shared national borders as a strong predictor of conflict between countries. Intuitively, shared international borders matter because they affect both the opportunity for interaction and the willingness to fight (Starr, 1978), which in many cases, is affected by the presence of resources and disputed territories. Interestingly, although similar forces should be prevalent across ethnic groups within countries, the role of (historical) ethnic borders as a source of internal conflict remains overlooked.

This seems an especially important gap in the literature as conflicts over land and territory are perceived to be especially prevalent in Africa. Indeed, $42 \%$ of individuals surveyed across 17 African countries in 2002 and 2003 stated that "boundary and land disputes" (the most prevalent first response) were the main catalysts for violent conflict between groups. ${ }^{2}$ According to a report by the EU and UN, "land issues have played a significant role in all but three of the more than 30 intra-state conflicts that have taken place in Africa since 1990" (EU-UN). Although these types of conflicts are extremely prevalent (44\% of conflict events and 47\% of conflicts between 1997 and 2015), they tend to be smallscale, local, and usually do not initially involve the government. Yet, these so-called non-civil conflicts tend to be linked to the escalation of conflict, evolving to become full-fledged civil wars (e.g, Côte d'Ivoire and Sudan) (Fjelde and Østby, 2014).

We aim to fill this gap in the literature by studying the relationship between historical ethnic borders and contemporary conflict in Africa. Specifically, we explore the relationship between the historical (and fuzzy) demarcation of ethnic territories and the prevalence and intensity of non-civil conflict (i.e., conflict events that take place at the local level and do not involve the government). We hypothesize that the fuzzy nature of these borders underlies contemporary disputes over land and territory. Central to our main argument is the fact that historical ethnic homelands are fundamental to group identities today (Horowitz et al., 1985), mainly because they highlight the ancestral ownership of the land (Fearon

\footnotetext{
${ }^{1}$ E.g., the role of resource discovery and exploitation, climatic shocks, economic poverty and inequality, lack of democratic institutions, weak property right protection, European colonization, and ethnic and religious diversity have been studied (see among others, Alesina et al. (2003); Miguel et al. (2004); Alesina et al. (2011); Bazzi and Blattman (2014); Berman and Couttenier (2015); Michalopoulos and Papaioannou (2016); Berman et al. (2017); McGuirk and Burke (2020)). See Herbst (1990, 2000) and Blattman and Miguel (2010) for surveys of the large conflict literature.

${ }^{2}$ These figures come from round 2 of the Afro-Barometer, where individuals were asked about the three main reasons for which groups fight in their country.
} 
and Laitin, 2011). Nonetheless, the demarcation and enforcement of these borders was not forcefully enforced in the past, as land was historically abundant and population scarce in precolonial Africa (Herbst, 2000). These conditions disincentivized the control of land and the "demarcation" of borders (Fanso, 1984). However, things dramatically changed during the post-colonial period (Herbst, 2000). Due to its late demographic transition, Africa experienced rapid population growth (increasing from 74 million in 1800 to 1.3 billion in 2019) characterized by low urbanization rates and large rural-rural migration. As a result, competition for resources became more salient as land became more scarce and marginal lands became more valuable (Boone, 2017). ${ }^{3}$ We argue that it is the "porosity" of these poorly demarcated historical borders that serves as catalyst for the emergence of conflict, especially when accompanied by increases in population or the presence of land suitable for agriculture. Indeed, these soft historical borders are conducive to the existence of weak ethnic (and personal) property rights, overlapping claims on resources (particularly agricultural land), and a higher likelihood of interethnic contact and encroachment. ${ }^{4}$

To test our main hypothesis, we combine georeferenced conflict data at the very fine local level from the Armed Conflict Location and Event Data Project (ACLED) (Raleigh et al., 2010) and the UCDP Georeferenced Events Dataset (GED) (Sundberg and Melander, 2013) with the spatial distribution of historical ethnic borders (Murdock, 1959). ${ }^{5,6}$ Specifically, by comparing artificial regions (i.e., grid cells of $50 \times 50 \mathrm{~km}$ ) within an ethnic homeland in a country, we explore whether the presence of historical ethnic borders predicts contemporary conflict across grid cells. Our results hint to the strong influence of historical ethnic borders on non-civil conflict in Africa. Indeed, both the intensive and extensive margins of contemporary conflict are concentrated in the proximity of historical ethnic borders. This strong empirical pattern holds regardless of whether we look at the presence, the number, or the total

\footnotetext{
${ }^{3}$ In Herbst (2000)'s words "Due to high population growth and the low carrying capacity of much of the land in Africa, there are now far fewer empty areas into which people can move [...] The land frontier has all but closed. The specter of a land shortage is a dramatic development because as late as two generations ago Africa was characterized by small concentrations of people surrounded by large amounts of open land."

${ }^{4}$ E.g., in 2019, an ethnic dispute between the Tiv and Jukun peoples made the headlines in Nigeria's national newspapers. The crisis started over the erection of a signboard that changed the name of a small town from a Tiv name to a Jukun name. This village is located in the Taraba State in the Jukun homeland according to Murdock's map. According to media, "[r]elations between the two ethnic groups, which has stretched for centuries has suffered as a result of politics, land ownership issues, indigene/settler syndrome, suspicion, and lack of political will" The West Africa Network for Peace Building says at least 600 persons have been killed in the Tiv/Jukun crisis. Similarly, in 2004, a border dispute made the headlines in Namibia's national newspapers, when the Ondonga Traditional Authority tried to install a senior headman in Ekoka, a tiny village east of Ekongo, located 25kms of the historical Ovambo-Heikum ethnic border. The Oukwanyama Traditional Authority formally protested that the area was under their jurisdiction, complaining that these were "tricks and machinations aimed at depriving the Ovakwanyama people of their traditional inheritance". This local dispute soon involved the two major ethnic groups in the country and affected national politics (Dobler, 2008).

${ }^{5}$ These two conflict datasets contain very disaggregated data that allows us to identify the location of many types of conflict including civil, non-civil, state based, non-state based, local, communal, and ethnic conflicts, among others. Importantly, in some cases, these types are not fully mutually exclusive as, e.g., ethnic conflict may also be part of a civil or local conflict or related to land disputes.

${ }^{6}$ Starting with Nunn (2008) the spatial distribution of ethnic homelands introduced in Murdock (1959) has been widely used in economics and related fields for diverse purposes; among others, identifying the spatial distribution of ethnic groups partitioned by the Scramble for Africa (Michalopoulos and Papaioannou, 2016), assigning pre-colonial cultural characteristics like the degree of political centralization (Michalopoulos and Papaioannou, 2013b) or social structure (Moscona et al., 2020), computing geographic characteristics of ethnic homelands (Fenske, 2014; Depetris-Chauvin and Özak, 2018), and estimating the intensity of the disease environment (Alsan, 2015; Depetris-Chauvin and Weil, 2018). As Moscona et al. (2020) have shown these borders have persisted and predict contemporary discontinuities in ethnic identification.
} 
length of historical ethnic borders.

While we show that initial OLS estimates are robust to a set of geographic and climatic controls as well as to country and ethnic group fixed effects, those estimated coefficients might still be biased. Indeed, historical ethnic borders are unlikely to be randomly assigned, while Murdock's map may contain non-trivial measurement error. To mitigate these concerns, we follow a theory-based instrumental variable strategy that exploits variations in the location of potential ethnic borders generated by a plausibly exogenous ethno-spatial partition of Africa. Specifically, our theoretical model of ethnic border formation predicts that the location of ethnic borders in a homogeneous world, in which ethnicities do not differ in their geographical, institutional, cultural, linguistic, historical, and ethnic characteristics, generates a Voronoi partition of the world. I.e., ethnic borders partition the world in such a way that an ethnicity's homeland contains all locations closest to its center of gravity compared to that of any other ethnicity. Based on these results, we create measures of the location, length and number of potential borders in each grid cell as predicted by the borders of the Voronoi regions generated by the centroids of historical ethnic homelands in Africa. Importantly, as further explained below, after accounting for country and ethnicity fixed-effects, these measures of potential ethnic borders are, at least in theory, orthogonal to any grid cell characteristics.

Using our instrumental variable strategy we find that grid cells with historical ethnic borders have 27 percentage points higher probability to experience conflict events. This probability increase represents roughly 124 percent of the mean value of prevalence of non-civil conflict in our sample; suggesting a sizable economic impact of borders. Indeed, when compared to other sources of conflict, the estimated impact of historical borders is substantially larger than the associated impacts of diamonds, minerals and oil. We also find that hosting a historical ethnic border increases in 7.9 percentage points the probability of conflict onset (i.e., being the initial location of a confrontation within a conflict dyad). While our IV estimates are conditional on country and ethnicity fixed-effects, thus ensuring that they are not driven by time-invariant country or ethnic characteristics, our results are robust to a battery of tests. ${ }^{7}$

Having documented the strong association between historical ethnic borders and non-civil conflict, we delve further into the potential mechanisms underlying this result. Specifically, we explore whether various characteristics of an ethnic border may amplify or dampen its effect on conflict. In particular, we study whether the role of borders is amplified at borders that are (i) agriculturally suitable, (ii) host natural resources such as minerals, (iii) overlaps with natural features that make the border less fuzzy, (iv) have experienced a recent increase in population (e.g, due to drastic climate change), and (v) in which culturally similar ethnicities interact.

Our analyses of potential mechanisms suggest that conflict increases at borders with higher agricul-

\footnotetext{
${ }^{7}$ In particular, our results are robust to alternative strategies for constructing the instrumental variable, to accounting for a large set of potential geographical and climatic confounders, to variations in grid cell sizes, and violations of various econometric assumptions. Additionally, our results are virtually unaltered when accounting for other sources of conflict, and the prevalence of conflict in pre-colonial times. Moreover, we show that accounting for contemporary inter-ethnic diversity, as measured by the number of languages spoken in the cell or the level of linguistic fractionalization of the population living in it, does not alter our main result. Furthermore, our results are robust to spatial autocorrelation and various strategies for clustering of standard errors. Also, we replicate our empirical analyses for grids of $10 \times 10 \mathrm{~km}$, $25 \times 25 \mathrm{~km}$, and $100 \times 100 \mathrm{~km}$ obtaining qualitatively similar results.
} 
tural potential. This supports our hypothesis that competition over productive land is a key mechanism underlying the strong positive impact of historical ethnic borders on modern conflict. We present four additional pieces of evidence for this explanation as an underlying mechanism: (i) exploiting information on the causes and issues of local conflicts, we find that conflict over territories and authority is more prevalent in the proximity of historical ethnic borders. Interestingly, we find that the proximity of historical ethnic borders does not drive conflicts related to religious issues. (ii) We document that conflict is more prevalent at historical ethnic borders that experienced larger population pressures during the second half of the $20^{\text {th }}$ century. This result echoes Herbst (1990)'s narrative on the problem of scarcity of land in rural areas after independence. (iii) We find that ethnic similarities and complementarities across historical borders matter for conflict. Specifically, we show that economic, cultural, and linguistic similarities exacerbate conflict at historical ethnic borders. Since similar ethnicities tend to share economic subsistence strategies, these results suggest there may exist more inter-ethnic competition for resources at the border, consistent with Spolaore and Wacziarg (2016) and Ray and Esteban (2017), who propose group similarity may be conducive to conflict. (iv) Using individual level data we document that land ownership is lower close to historical ethnic borders. In particular, we show that individuals are less likely to own land if they live close to a border compared to others of the same ethnic group living in the same historical ethnic homeland within a country.

Further, we explore whether the tangibility, observability and immutability of ethnic borders may help prevent conflict. Specifically, we analyze if geographical characteristics that are complementary to border demarcation mitigate the effects of historical borders on contemporary conflict. Our results suggest that certain geographical features of historical ethnic borders, e.g., congruence with water bodies (rivers, lakes, and seas), may have decreased their fuzziness and thus decreased the likelihood of conflict. Furthermore, we find that the concordance of historical ethnic borders with de jure borders, e.g., administrative borders (both at the subnational and the international level), also decreases conflict. This result lends support to our hypothesis that border fuzziness may be conducive to weak inter-ethnic property rights and overlapping claims, which may result in conflict. Indeed, by allocating authority and property, de jure borders lower these problems.

Our paper is the first to explore the role of historical ethnic borders on non-civil conflict in Africa, contributing to various strands of literature. First, we contribute to the literature on the determinants of conflict in Africa, exploring a largely overlooked and highly prevalent type of conflict and identifying a novel source of conflict. Second, we add to the literature on the role of borders for economic and political outcomes, which has mainly focused on the role of contemporary national borders (Miguel, 2004; Bubb, 2013; Aker et al., 2014; McCauley and Posner, 2015; Michalopoulos and Papaioannou, 2013a, 2016), and has largely ignored the role of internal borders and their role on conflict. 8 Third, we also contribute to a large literature (mostly in political science based on qualitative analyses and case studies) documenting the importance of competition over land as a catalyst of conflict (Fearon and Laitin, 2011; Boone, 2017; Acemoglu et al., 2017; Berman et al., 2019). Fourth, we add to the literature on the effect of cultural differences (Alesina and La Ferrara, 2005; Spolaore and Wacziarg, 2016; Desmet

\footnotetext{
${ }^{8} \mathrm{~A}$ notable exception is Bazzi and Gudgeon (2021), which studies the role of changing administrative borders in Indonesia.
} 
et al., 2017; Ray and Esteban, 2017). Fifth, we also contribute to a fruitful research agenda that studies the geographic patterns of within-country conflict, which has focused on the effects of price, climate and resource shocks (Berman and Couttenier, 2015; Berman et al., 2017; Harari and Ferrara, 2018). Sixth, we contribute to the literature on the interaction of ethnicity and landownership in Africa (Bubb, 2013; Boone and Nyeme, 2015). Seventh, our work adds to the literature on the historical drivers of contemporary conflict. ${ }^{9}$ Finally, we contribute to the growing literature on the deep-determinants of economic development and the persistent effects of historical institutions (Diamond, 1997; Acemoglu et al., 2005; Galor and Özak, 2016; Guiso et al., 2009; Nunn and Wantchekon, 2011).

The remainder of the paper is organized as follows. In section 2 we provide a conceptual framework to understand the potential relationship between historical ethnic borders and contemporary conflict. In section 3 we present the data and outline the empirical strategy for our analysis. In section 4 we present our main empirical results and explore the robustness of our findings. In section 5 we explore the mechanisms behind our main results. Section 6 concludes. Additional results and our theoretical model for border location are presented in the appendix.

\section{Conceptual Framework: Why Historical Ethnic Borders Matter for Conflict}

While the relationship between contiguity and interstate conflict is a well documented empirical regularity, to the best of our knowledge, there is no literature directly linking ethnic borders to intrastate conflict. Indeed, a large literature in economics, political science, and international studies has discussed the reasons why neighboring countries are more likely to fight. To the extent that similar mechanisms underlying interstate border conflict could also affect conflict across ethnic groups, our work relates and benefits from insights of previous research on shared national borders. Further, our work is closely associated with the strand of the conflict literature that has focused on land disputes as a key catalyzer of interethnic conflict. Since violent ethnic confrontations over land may be more prevalent at locations where "de facto" ethnic borders are poorly delineated and demarcated, exploring the land conflict literature also provides clues about potential underlying mechanisms for our reduced form results. We next summarize the main empirical and theoretical contributions of the conflict literature regarding the role of borders and land disputes.

The seminal contribution of Starr (1978) introduced a conceptual framework for understanding conflict at national borders in terms of opportunity and willingness. The former is inevitably related to the concept of proximity and an obvious implication of Tobler's first law of geography when applied to conflict: an actor (i.e., a potential warring faction) interacts most with other actors who are close. Translated into our setting, ethnic groups sharing borders will tend to have a greater ease of interaction with one another. With an increasing number of interactions between them, the number of disagreements (in some cases involving fundamental conflicts of interest) would also potentially increase (Starr and Most, 1976). Since sharing a border promotes this type of interactions, contiguous ethnic groups would be more likely to experience conflict due to incompatibility of interests. It is important

\footnotetext{
${ }^{9} \mathrm{~A}$ number of studies have documented that modern conflict in Africa has deep historical roots due to the European partition (Michalopoulos and Papaioannou, 2016), precolonial conflict (Besley and Reynal-Querol, 2014), and exposure to centralized institutions (Depetris-Chauvin, 2014).
} 
to note, however, that more interactions could also reduce conflict propensity since cultural exchange and greater economic interactions may lower the incentives to fight.

Borders can also impact actors' willingness to fight (Starr, 1978). While its precise definition remains somehow elusive in the literature, willingness has been linked to the idea of salience, understood as the importance or value of a territory. Indeed, borders may act as indicators of great salience of the territory along or behind borders. In this sense, if a valuable territory is threatened or contested, a group should be more willing to fight. In fact, Vasquez (1993) argues that borders that traverse regions of little value are less likely to ignite conflict. ${ }^{10}$ Further, borders can harbor valuable natural resources like oil, minerals, diamonds, rivers or lakes, creating the potential for conflict (Toset et al., 2000; Brochmann and Gleditsch, 2012; Caselli et al., 2015).

Land can also play a crucial role in the "willingness" to fight at the border. For instance, the sons-of-the-soil (SoS) conflict literature points to ethnic migration and competition over land as a key determinant of conflict. Put simply, an SoS conflict is characterized by a local confrontation over land (or other natural or economic resource, including jobs and government services) between an ethnic group which claims to be indigenous, and thus the rightful heir to the (ancestral) land, and a relatively recent, ethnically distinct migrant group to this region from other parts of the same country (Fearon and Laitin, 2011). While the SoS's theory was originally applied to India, it clearly is applicable more generally, particularly to the African context (Platteau, 2002). ${ }^{11}$ Indeed, Bates (2008) argues that explosive population growth, territorial expansion and competing claims over land worked as a combustible combination for domestic tensions in several Sub-Saharan African countries. ${ }^{12}$ For instance, Boone (2017) documents several ethnic conflicts related to land in 13 different sub-Saharan African countries. ${ }^{13}$

The "willingness" to fight could also depend on the degree of similarity between the groups at both sides of the border. The role of heterogeneity, relatedness, and similarity in conflict has been theoretically and empirically studied in various contexts. In fact, previous literature has focused on the role of heterogeneity and relatedness between groups and emphasized the importance of shared interests and preferences to understand the role of economic and cultural similarities in conflict (Alesina et al., 2003; Alesina and La Ferrara, 2005; Spolaore and Wacziarg, 2009). On the one hand, it has been suggested that closely related groups, which tend to have similar preferences over rival goods (e.g., land), will be more likely to fight over those types of goods. On the other hand, it has been suggested that dissimilar groups, which tend to have different preferences over public goods (e.g., policies or public goods in general), will be more likely to fight over those types of goods. In particular, Ray

\footnotetext{
${ }^{10}$ To test this hypothesis, Starr (2002) constructs a measure of salience based on the presence population concentrations and a set of infrastructure facilities within $50 \mathrm{~km}$ of national borders; finding that salience was not correlated with conflict. Needless to say, an empirical analysis purely based on Starr (2002)'s measure may be subject to endogeneity problems.

${ }^{11}$ As Platteau (2002) explains, "An immediate upshot of the growing scarcity of land is that strange farmers are being increasingly denied their rights of access to land, especially to plots of relatively high quality. In the Senegal River Valley, for example, the local Haalpulaar (Toucouleur) communities have become concerned that land will not be available in sufficient amounts for their children and grandchildren. [...] Similar events have occurred in many places in sub-Saharan Africa".

${ }^{12}$ The steady decline in land-labor ratios is perhaps one of the most remarkable stylized facts in African agriculture (Jayne et al., 2010).

${ }^{13}$ Boone (2017) identifies land conflicts in Kenya, Malawi, Ghana, Nigeria, Burkina Faso, Senegal, Ivory Coast, Rwanda, DRC, Uganda, Mali, Tanzania, and Zimbabwe.
} 
and Esteban (2017) highlight the importance for conflict of economic similarities and contestation over resources. ${ }^{14}$ Anecdotal evidence of conflicts between groups that engage in the same mode of production is abundant, such as the conflict among herders in pastoral areas of Northern Kenya (e.g., Gabra versus Borana) and among farmers fighting over property rights and land tenure in Nigeria (e.g., Tiv versus Jukun in the Taraba State).

While the aforementioned theories shed some light as to why two contiguous groups may fight, it remains silent about the location of violence. Nonetheless, the spatial concentration of conflict in the proximity of historical ethnic borders can be rationalized by them. Indeed, historical ethnic borders may be the locations of first contact and encroachment. Thus, given the strong dependence on agriculture in Africa (especially in Sub-Sahara), as population pressure increases, it pushes the agricultural frontier, making marginal lands more valuable. If this increasing scarcity of land couples with porous historical ethnic borders, which are more de facto than de jure, conflict could emerge due to overlapping claims on resources under vague property rights.

\section{Data and Empirical Strategy}

In this section we introduce the data employed in the analysis, in particular, the geocoded measures of contemporary conflict and historical ethnic borders across Africa. Additionally, we explain the main empirical hurdles faced in the exploration of the association between historical ethnic borders and contemporary conflict in Africa. Furthermore, we describe the strategies we employ in order to mitigate these potential concerns. Given our empirical strategy, our main analyses combine data on contemporary conflict, historical ethnic borders, as well as ethnic, geographical, linguistic and cultural characteristics, across all cells of size $50 \mathrm{~km} \times 50 \mathrm{~km}$ in Africa. ${ }^{15}$ We explore the robustness of our results by exploiting variations in cell sizes, additionally considering cells of sizes $100 \mathrm{~km} \times 100 \mathrm{~km}, 25 \mathrm{~km} \times 25 \mathrm{~km}$ and $10 \mathrm{~km} \times 10 \mathrm{~km}^{16}$

\subsection{Main Dependent Variables: Conflict Prevalence, Incidence, Onset and Types}

To explore the geographical distribution of conflict across Africa and its relation to historical ethnic borders we use the two main sources of georeferenced conflict data available for Africa: (a) the Armed Conflict Location and Event Data Project (ACLED) and (b) the Uppsala Conflict Data Program (UCDP) \& Peace Research Institute Oslo (PRIO) Georeferenced Event dataset (UCDP-GED). Both datasets are widely used in the literature on conflict since they provide high quality disaggregated and georeferenced data for various types of conflicts (Raleigh et al., 2010; Sundberg and Melander, 2013).

We employ data from ACLED for the 1997-2014 period, which includes information on the location (latitude and longitude) and severity (number of fatalities) of different types of conflict episodes (i.e.,

\footnotetext{
${ }^{14}$ In their words: "Economic similarity, not difference, can breed tensions; indeed, such tensions, involving as they do the direct contestation of resources" (Ray and Esteban, 2017).

${ }^{15}$ We exclude small islands from the analysis given data constraints.

${ }^{16}$ The construction of the grid is based on the whole globe, i.e. a rectangle ranging from -180 to 180 degrees longitude and -90 to 90 latitude. This globe is reprojected using the cylindrical equal area projection to ensure all cells have the same area. Once the whole globe is reprojected, the rectangle is split into a grid with the specified size. After the creation of this fishnet, we retain for the analysis only those cells that are located in Africa.
} 
battles, violence against civilians, riots and protests) that involve either the government, rebel group militias, or civilians. Given our interest on studying local conflict that does not involve the government and mostly involves disputes over land and territory between ethnic groups, we exploit information in ACLED to construct several measures of conflict. Our main measure of non-civil conflict follows Moscona et al. (2020) and includes all conflict events that do not include the government or rebels seeking to replace the central government as one of the actors. Additionally, we construct a measure of local conflict defined as all conflict events for which both actors engaged in violence are geographically local and/or ethnically local groups (Moscona et al., 2020). We also exploit the measure of ethnic conflict proposed in Depetris-Chauvin et al. (2020) and follow a similar approach to construct a measure of land-related conflict. To do so, we exploit the fact that ACLED includes a description of its conflict observations. We code conflict as land-related if specific keywords related to land are documented in the dataset. ${ }^{17}$

For each aforementioned conflict definition we construct a measure of (i) conflict prevalence at the grid cell level, i.e. a dummy that equals 1 if during the study period any conflict event of a specific type has occurred in a given cell and zero otherwise. Additionally, we use the information on the severity and recurrence of conflict events to construct three measures of conflict intensity at the grid cell level. Specifically, we measure (ii) the number of conflict events that occurred in a given cell, (iii) the fraction of years with at least one conflict event in a given cell, and (iv) the number of casualties associated with these events in a given cell. Figure A.2(a) depicts the prevalence of non-civil conflict in Africa at the $50 \mathrm{~km} \times 50 \mathrm{~km}$ grid cell level according to ACLED. Additionally, Figures A.2(b)-A.2(d) depict the various measures of conflict incidence, i.e., the number of deaths, the number of events, and the share of years with conflict.

Additionally, we employ data from UCDP-GED for the 1989-2017 period, which includes information on the location and severity of all major episodes of violent conflict to construct similar measures of prevalence and incidence of conflict. In particular, we construct measures of prevalence of nonstate-based conflict and communal conflicts. Unlike ACLED, UCDP-GED focuses on major violent conflicts among warring factions. Specifically, a conflict event is included in UCDP-GED if in any year during the period of analysis there are at least 25 deaths in the conflict between a given pair of warring factions (i.e., a dyad). Thus, UCDP-GED follows the whole history of a conflict and permits us to identify the location where conflict between any set of warring factions started. With this information we construct two additional measures of conflict: (v) first onset at the grid cell level, i.e. a dummy that equals 1 if any conflict started in a given cell and zero otherwise, and (vi) the number of onsets at the grid cell level, i.e. the number of conflicts that started in a given cell. Figure A.3(a) depicts the prevalence of non-state-based conflict in Africa at the $50 \mathrm{~km} \times 50 \mathrm{~km}$ grid cell level according to UCDPGED. Additionally, Figures A.3(b)-A.3(d) depict the various measures of conflict incidence according to UCDP-GED, i.e., the number of deaths, the number of events, and the share of years with conflict. Finally, Figures A.3(e)-A.3(f) depict the location and the number of conflict onsets in each cell.

\footnotetext{
${ }^{17}$ Example of such keywords are "land", "land dispute", "dispute over land", "clash over land", "land invasion", or "over disputed land".
} 


\subsection{Main Independent Variable: Historical Ethnic Borders}

We exploit information on location of historical ethnic borders using data on the spatial distribution of ethnic homelands at the eve of colonization (Murdock, 1959). The so-called Murdock map presents the location of ethnic homelands in Africa according to the classification of ethnicities provided by Murdock (1959). This map has been widely and effectively used in economics, history, anthropology, and political science. ${ }^{18}$ Although potentially mismeasured, since it is a historical map and ethnic borders are soft and fuzzy, it has been shown that nonetheless it captures the relevant information (Michalopoulos and Papaioannou, 2013b; Moscona et al., 2020). For our analyses, we use the geocoded version introduced in Nunn (2008). ${ }^{19}$ Figure 1(a) depicts the distribution of ethnic homelands in Murdock's map.

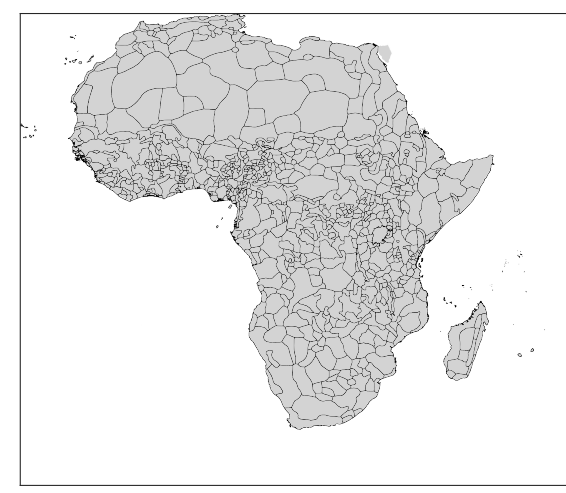

(a) Murdock Map

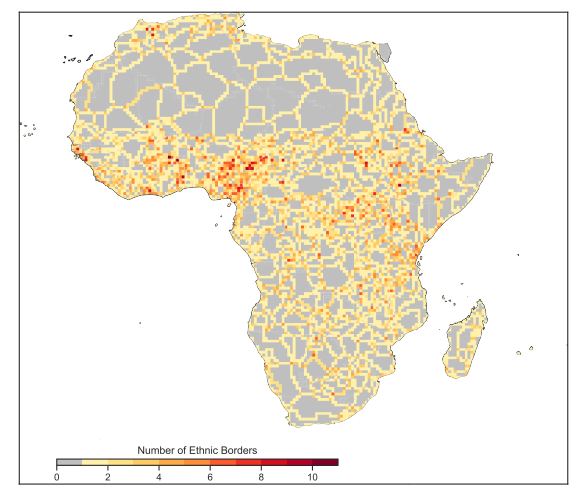

(c) Number of Borders

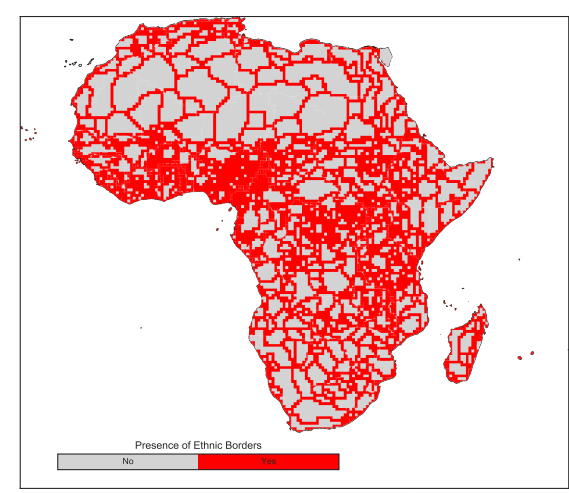

(b) Presence of Borders

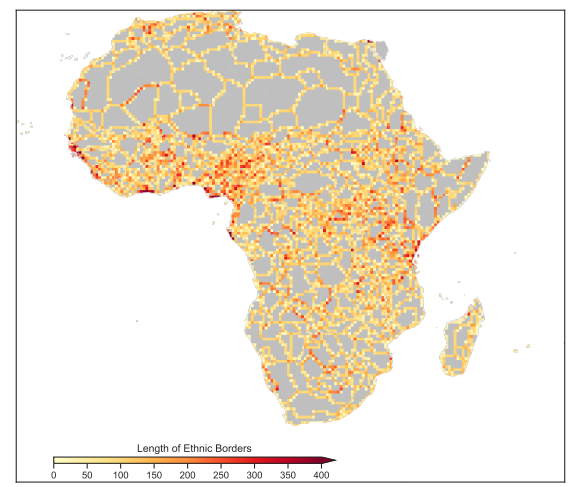

(d) Length of Borders

Figure 1: Historical Ethnic Borders in Africa

Given the Murdock map and our grids of cells of various sizes, we construct measures of presence and intensity of historical ethnic borders at the grid cell level. In particular, we measure the presence of a historical ethnic border in a grid cell as a dummy that equals 1 if for some ethnic group the border of its homeland in the Murdock map intersects the cell. Additionally, we generate various measures of the intensity of exposure to historical ethnic borders by counting the number of borders that exist in a grid cell, as well as the length of the borders in each cell. Figures 1(b)-1(d) depict these various

\footnotetext{
${ }^{18}$ There are more than 1700 citations to Murdock (1959) on Google Scholar (verified on July 25, 2018).

${ }^{19}$ The map is available at https://worldmap.harvard.edu/data/geonode:Murdock_EA_2011_vkZ
} 
measures.

To explore the robustness of our analysis, we also use other ethnographic sources to identify the historical core locations and borders of ethnicities. In particular, Weidmann et al. (2010) provide an alternative ethnographic map (GREG), which depicts the geographical distribution of ethnicities circa $1960 .^{20}$ Additionally, we use the core locations of ethnicities in the precolonial era as identified in the Ethnographic Atlas (Murdock, 1967) and the Atlas of Precolonial Societies (Müller, 1999). Although these Atlases do not provide the location of borders, they allow us to construct alternative instrumental variables based on those core locations.

\subsection{Empirical Strategy}

In order to explore the association between historical ethnic borders and contemporary non-civil conflict in Africa, we estimate a linear probability model of the form:

$$
\text { Conflict }_{i c e}=\alpha+\beta \text { EthnicBorder }_{i c e}+\gamma^{\prime} X_{i c e}+\delta^{\prime} G_{i c e}+\Phi_{c}+\Theta_{e}+\varepsilon_{i c e}
$$

where Conflictice is one of our four measures of conflict computed for the grid $i$ located in country $c$ in ethnic homeland $e$. EthnicBorder ${ }_{i c e}$ is one of our three indicators of ethnic borders: a dummy for whether at least one ethnic border intersects the grid, the number of ethnic borders in the grid, and the total length of those borders (in logs). $X_{i c e}$ is the vector of basic geographic and climatic controls. The vector $G_{i c e}$ includes additional control variables that may constitute potential drivers of conflict and will be analyzed in our robustness analyses. $\Phi_{c}$ and $\Theta_{e}$ refer to a full set of country and ethnicity fixed effects, respectively. Finally, $\varepsilon_{i c e}$ is an error term, which is allowed to be heteroskedastic and correlated at the country level. Thus, in all our analyses we report standard errors that are heteroskedasticity-robust and clustered at the country level. ${ }^{21}$

There are several potential threats to causally identifying the impact of historical ethnic borders on contemporary conflict. First, given the historical nature of the measure of ethnic borders, as well as the fact that ethnic borders are potentially soft and fuzzy, the main independent variable in our analysis may be mismeasured. This would suggest that the association between historical ethnic borders and contemporary conflict based on ordinary least squares may be biased. Second, one may worry that the observed association may reflect the reverse causality from ethnic conflict to ethnic borders. Indeed, it is conceivable that the location of ethnic borders is the result of ethnic conflict. Nevertheless, given the temporal structure of the data, it is not feasible that contemporary conflict determines historical ethnic borders reflecting the African pre-colonial period. A more plausible concern is that historical drivers of inter-ethnic interaction (conflict, trade) may codetermine the location of historical ethnic borders and contemporary conflict potentially generating biases in any direction in our OLS estimation. ${ }^{22}$

\footnotetext{
${ }^{20}$ GREG is constructed based on the Soviet Atlas Narodov Mira and focuses on politically relevant groups for the study of contemporary conflict. So, it may reflect a more modern distribution of ethnic borders, which may be subject to further concerns of endogeneity and reverse causality in the study of the relation between the spatial distribution of ethnic groups and contemporary conflict.

${ }^{21}$ In additional robustness analyses we show that applying alternative levels of clustering at the ethnic or countryethnicity level or accounting for spatial autocorrelation does not change our main results (Table C.12).

${ }^{22}$ In particular, historical ethnic conflict may have persisted in a given location or may have given rise to other types of
} 
Finally, as the previous case suggests, the observed association between historical ethnic borders and contemporary conflict may be governed by omitted geographical, institutional, cultural, linguistic, historical, and ethnic factors.

Our empirical analysis exploits several strategies to mitigate potential concerns regarding the role of reverse causality, omitted variables, and mismeasurement in the observed association between historical ethnic borders and contemporary conflict in Africa. As formalized in (1), our first strategy is to control for an extensive set of observables: (i) we account for country fixed-effects, and thus for any unobservable time-invariant characteristics at the country level. Specifically, accounting for country fixed-effects mitigates concerns that our analysis reflects countries' geography, (colonial) history, institutions or culture. Moreover, it ensures that the observed association is driven more by local (cell-level) characteristics than by global (country- or regional-level) ones. (ii) We account for ethnicity fixed-effects and thus for any unobservable time-invariant characteristics at the ethnicity level. In particular, by accounting for ethnic fixed-effects, we ensure that our results are not driven by any characteristics of the ethnicities inhabiting a cell. (iii) We account for a large set of geographical and climatic characteristics of each cell that may be correlated with both the existence of historical borders and contemporary conflict. Importantly, we control for key drivers of population density, ethnic diversity, trade, and economic development and thus indirectly for their effect on conflict. Specifically, we account for a cell's absolute latitude, longitude, elevation above sea level, temperature and precipitation, caloric and agricultural suitability.

Additionally, in our main empirical analysis we follow an instrumental variable approach based on the potential location of historical ethnic borders. In particular, as shown in Appendix B and as suggested by the theoretical literature, in a homogeneous world, in which ethnicities do not differ in their geographical, institutional, cultural, linguistic, historical, and ethnic characteristics, the theoretical location of ethnic borders generates a Voronoi partition of the world. I.e., ethnic borders partition the world in such a way that an ethnicity's homeland contains all locations that are closer to its center of gravity compared to that of any other. Based on these results, we create measures of the location, length and number of potential borders in each grid cell as predicted by the borders of the Voronoi regions generated by the centroids of historical ethnic homelands in Africa. Importantly, as further explained in the following subsection, these measures of potential ethnic borders are, at least in theory, orthogonal to any grid cell characteristics, which is our unit of analysis. In fact, as we show in section 4.2 , they strongly predict historical ethnic borders and this association is remarkably unaffected as we account for a battery of geographic and climatic covariates. ${ }^{23}$ These results are robust to the selection

conflict that persisted in the same geographical area. Simultaneously, ethnic borders may have formed in locations where conflict took place. Thus, historical ethnic conflict would be a potentially omitted variable in our analysis potentially biasing the estimate upwards. Similarly, historical trade between ethnicities may have occurred at locations that became borders and improved ethnic relations permanently. Thus, omitting historical trade could potentially downward bias the OLS estimate. Likewise, if historical ethnic borders had low population densities in the past, which may have persisted to the contemporary era, they may have lower levels of conflict than non-border locations, which would also potentially downward bias the OLS estimate.

${ }^{23} \mathrm{We}$ also expand the set of variables to document the strength of the instrumental variable results. Specifically, we account for ruggedness, difficulty of mobility, disease environment, ecological diversity, the presence of rivers (or their length), the presence of coasts (or their length), the presence of water bodies (perennial, fluctuating, seas), and the presence of ecological borders. 
of the core location of ethnicities as well as to the method of construction of the Voronoi partition. In particular, using other historical ethnographic sources to identify the core location, or choosing the most agriculturally suitable locations as the core, does not affect the qualitative results. Furthermore, we account for other sources of conflict identified in the literature. In particular, we control for the presence of diamonds, minerals, oil, cities, and capitals, as well as cell's distances to these sources of conflict.

While our IV strategy should mitigate concerns due to potential mismeasurement in historical ethnic borders, we also exploit changes in the size of the grid cell to further address this concern. In particular, the potential measurement error should differ as the size of the grid cell changes. Specifically, a measure of the presence of historical ethnic borders has potentially less measurement error if cells are larger. We also provide improved bounds on the true causal effect of historical borders in the presence of non-classical measurement error. ${ }^{24}$

\subsection{Instrumental Variable: Potential Historical Ethnic Borders}

This section explains the construction and properties of our instrument. We exploit the predictions of our theoretical model (Appendix B) to construct potential borders for ethnicities in Africa. In particular, our model suggests that if history, geography, culture, institutions, etc. do not play a role, the theoretical location of ethnic borders partitions the world into a unique set of homelands. Specifically, given the central locations of ethnic groups, the homeland of some ethnicity $i$ should be composed by the regions that are closer to its center than to the center of any other ethnicity $j \neq i$, i.e., theoretically borders create a Voronoi partition of the world. Importantly, this unique Voronoi partition depends solely on the location of the centers and some notion of distance, independent of any characteristics of the ethnicities or the geography of the world. In particular, given the central locations of ethnicities, the Voronoi partition would not change if we were to change the geography or climate of Africa, or change the characteristics of the ethnicity linked to the center. ${ }^{25}$ In fact, this Voronoi partition of the world is a global property of the set of centers for any given notion of distance employed. Thus, the location of Voronoi borders is independent of any local characteristics of the region where the border is located, in particular, of our unit of analysis - a grid cell.

Based on this theoretical prediction we generate our measure of potential borders following a twostep procedure: (i) we identify a center for each ethnicity and (ii) we construct the Voronoi partition based on these centers and a notion of distance. Clearly, there are many potential locations that could be taken as central to an ethnic group including its most important city, its most densely populated location, or its earliest populated location. Nonetheless, using this type of locations may not be feasible due to lack of data (e.g. archaeological or historical) for all ethnic groups or may create endogeneity concerns due to the direct effects that some of these characteristics may have on conflict. Thus, we use locations that may be plausibly exogenous and should have high predictive power. Specifically, for our

\footnotetext{
${ }^{24}$ Specifically, as Black et al. (2000) show, in our setting the true causal effect in the presence of non-classical measurement error will lie between the OLS and IV estimates.

${ }^{25}$ E.g., given the central locations, if we were to shuffle the ethnographic characteristics and history of all ethnicities, the Voronoi partition would remain unchanged. Similarly, if the geography and climate of Africa was different, it would also not affect the partition, given the central locations.
} 
main analyses, we use the geographical centroid of each historical ethnic homeland, i.e., the location identified by the average latitude and longitude of all points in the homeland, as the centers for the construction of the Voronoi partition.

The use of centroids has various advantages that follow from their geometrical properties and relations to the underlying polygons. Particularly important for our analysis are the following: (i) centroids are global properties of each ethnic homeland (polygon), and thus are not affected by characteristics of specific locations (i.e., a grid cell in our analysis) in the homeland; and (ii) centroids are stable to perturbations in the polygons. E.g., rotations or scalings of the homeland will affect the location of borders, but not the location of the centroid. Hence, centroids do not have a 1-1 relation with the geometry of the ethnic homeland. In particular, while every polygon has a unique centroid, the same centroid may be associated with different polygons (see Figure 2(a)). Thus, knowing the location of the centroid does not allow one to predict the underlying geometry that generated the centroid. Moreover, knowing the location of all the centroids also does not uniquely identify the original shapes that generated them either (see Figure 2(b)). Nevertheless, the Voronoi partition generated by the centroids should capture the global structure of the underlying original polygons and borders.

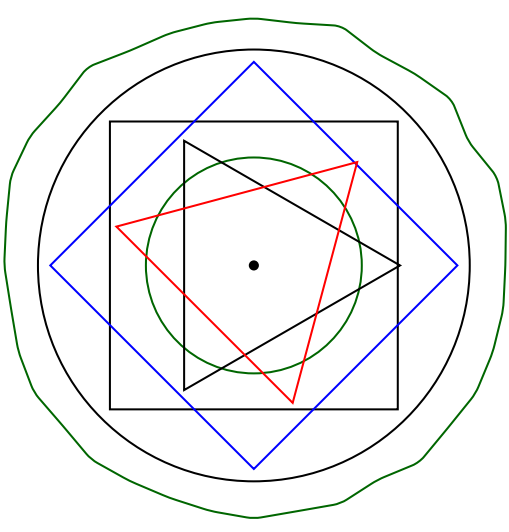

(a) No 1-1 Relation.
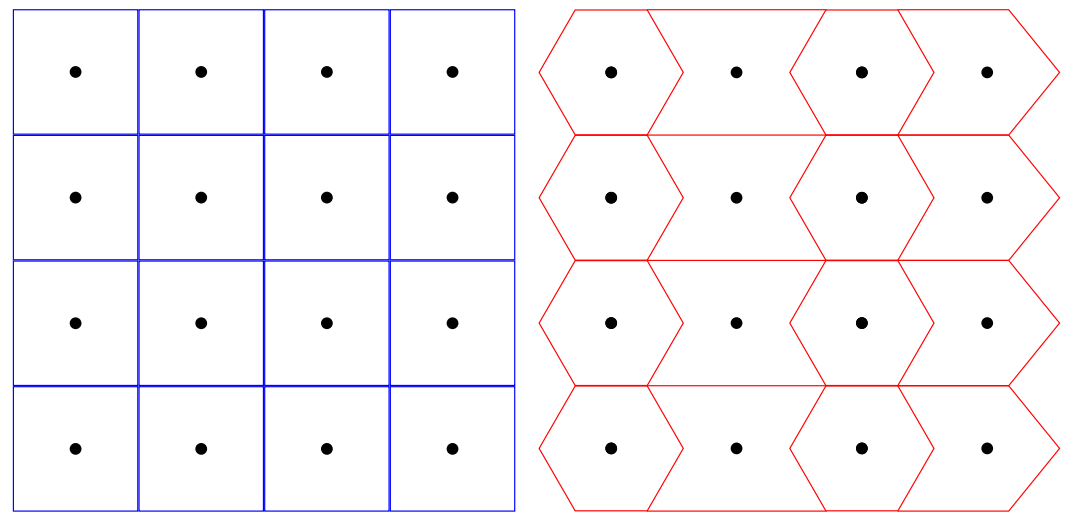

(b) No 1-1 Relation.

Figure 2: Centroids and Polygon Shapes.

Based on these centroids and using geodesic distances, we construct the unique Voronoi partition of Africa to create our main instrumental variable. Since this Voronoi partition is a global property of the set of centroids, and centroids are a global property of the ethnic homelands, our measures of potential historical ethnic borders at the cell-level should be theoretically orthogonal to cell-level characteristics. Moreover, by accounting for country and ethnicity fixed effects, as well as the latitude and longitude of each grid cell, our analysis strengthens the plausibility of the (conditional) exogeneity assumption of the instrument.

In order to understand our construction of potential borders, let's exemplify the construction of the instrument in a simplified world. Figure 3 depicts on a grid of cells a two dimensional squared world with two ethnicities $A$ and $B$. The homeland of ethnicity $A$ is shown as the region in blue (NW-SE line pattern) and the one of ethnicity $B$ in red (NE-SW line pattern). The true ethnic border between $A$ and $B$ is depicted in purple. Given these conditions, the centers of these homelands are shown as 


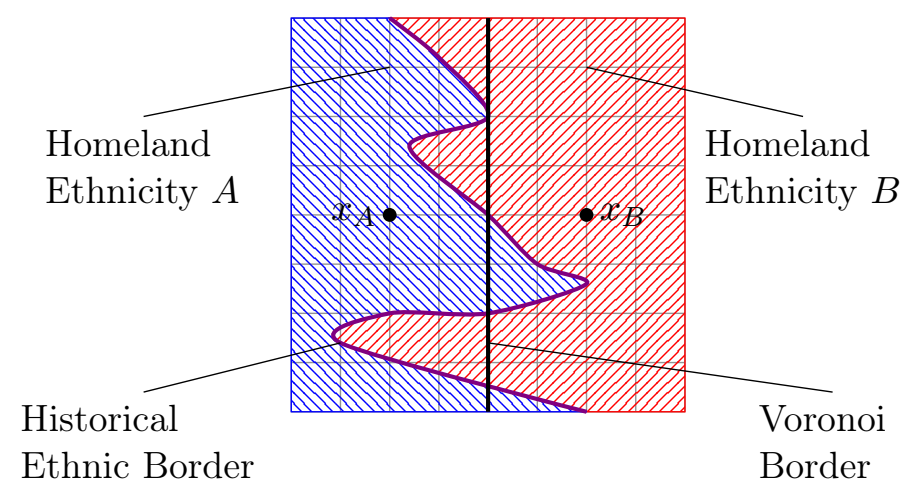

Figure 3: Potential Border Construction: A Simplified Example

points $x_{A}$ and $x_{B}$. If we use the Euclidean distance as our notion of distance, the unique Voronoi partition generated by the centers $x_{A}$ and $x_{B}$ splits the world in the two depicted rectangular Voronoi regions separated by the black line depicting the Voronoi border, i.e., the potential ethnic border. It is important to note, that given the shape of the world, the distance function, and the centers $x_{A}$ and $x_{B}$, the Voronoi partition and consequently the Voronoi borders are independent of the precise shape of the actual ethnic borders, any characteristics of these ethnicities, their homelands or subregions within their homeland. In particular, notice that the location of the Voronoi border is constructed independently of any characteristic of grid cells, which confirms that potential borders are orthogonal to the characteristics of our unit of analysis.

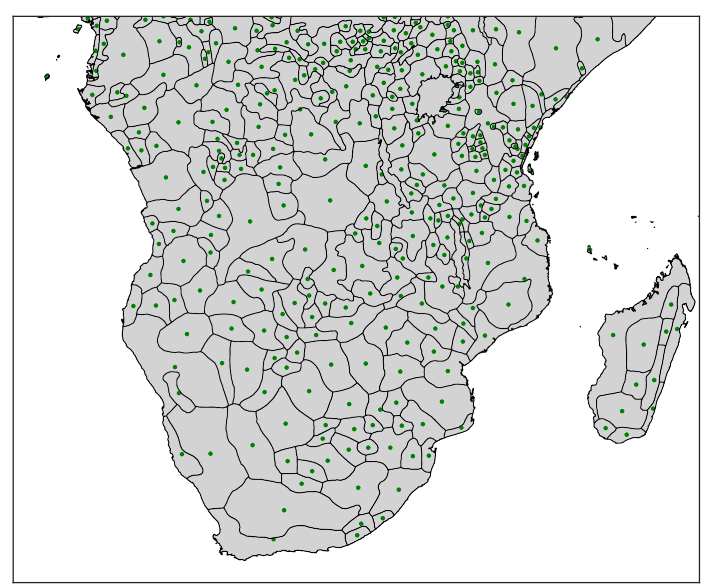

(a) Historical Borders \& Centroids of Ethnic Homelands

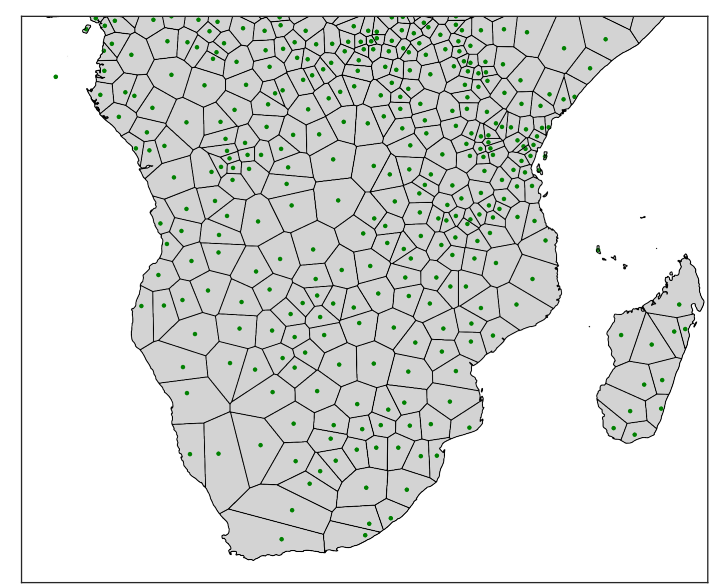

(b) Potential Borders \& Centroids of Ethnic Homelands

Figure 4: Historical Ethnic Borders, Centroids and Potential (Voronoi) Borders in Africa

Figure 4(a) depicts for each ethnic group in the southern part of Africa its historical ethnic border and centroid. Additionally, Figure 4(b) depicts the centroids and the unique potential (Voronoi) ethnic borders associated with them. Our analysis uses these potential borders as an instrument for historical ethnic borders. Visual inspection suggests a positive correlation between the location of historical and potential ethnic borders, suggesting that potential borders predict the location of historical ethnic 
borders. We explore this association more formally in section 4.2, as well as the association between the length and number of potential borders and historical borders.

In our robustness analysis, we study the sensitivity of our results to the choice of center and the method for construction of the Voronoi borders. First, we use different measures of land quality to identify locations with high agricultural productivity to be used as centers for ethnic groups. Second, we use the central location of ethnicities as reported in the Ethnographic Atlas (Murdock, 1967), teh Atlas of Precolonial Societies (Müller, 1999), and GREG (Weidmann et al., 2010). Third, we vary how, given the center we compute the location of Voronoi borders. In particular, instead of using geodesic distances, which assume geography and climate do not affect mobility, we employ migratory distances based on the Human Mobility Index (Özak, 2010, 2018). Appendix C.2.13 shows the results of these robustness analyses.

\section{Empirical Results}

\subsection{Baseline OLS Results}

In order to ease comparison with previous work on conflict we carry out our empirical analysis on $50 \mathrm{~km} \times 50 \mathrm{~km}$ grid cells and exploit conflict data from ACLED. Nonetheless, in section 4.3 we present robustness checks to using alternative conflict data and different grid cell sizes.

Table 1: Historical Ethnic Borders and Conflict (OLS)

\begin{tabular}{|c|c|c|c|c|c|c|c|c|}
\hline & \multicolumn{8}{|c|}{ Conflict } \\
\hline & \multicolumn{5}{|c|}{ Prevalence } & \multicolumn{3}{|c|}{ Intensity } \\
\hline & \multicolumn{5}{|c|}{ Presence } & \multirow{2}{*}{$\frac{\text { Events }}{(6)}$} & \multirow{2}{*}{$\frac{\text { Years }}{(7)}$} & \multirow{2}{*}{$\frac{\text { Fatalities }}{(8)}$} \\
\hline & (1) & $(2)$ & (3) & (4) & $(5)$ & & & \\
\hline Presence of Ethnic Border & $\begin{array}{l}0.137^{* * *} \\
(0.022)\end{array}$ & $\begin{array}{l}0.093^{* * *} \\
(0.012)\end{array}$ & $\begin{array}{l}0.072^{* * *} \\
(0.016)\end{array}$ & $\begin{array}{l}0.066^{* * *} \\
(0.015)\end{array}$ & $\begin{array}{l}0.059 * * * \\
(0.015)\end{array}$ & $\begin{array}{l}0.127^{* * *} \\
(0.029)\end{array}$ & $\begin{array}{l}0.012^{* * *} \\
(0.003)\end{array}$ & $\begin{array}{l}0.066^{* *} \\
(0.027)\end{array}$ \\
\hline Country FE & No & Yes & Yes & Yes & Yes & Yes & Yes & Yes \\
\hline Ethnic FE & No & No & Yes & Yes & Yes & Yes & Yes & Yes \\
\hline Geographic Controls & No & No & No & Yes & Yes & Yes & Yes & Yes \\
\hline Climatic Controls & No & No & No & No & Yes & Yes & Yes & Yes \\
\hline Adjusted- $R^{2}$ & 0.03 & 0.18 & 0.32 & 0.32 & 0.32 & 0.37 & 0.36 & 0.34 \\
\hline Observations & 14078 & 14078 & 14078 & 14078 & 14078 & 14078 & 14078 & 14078 \\
\hline
\end{tabular}

Notes: Heteroskedasticity robust standard error estimates clustered at the country-level are reported in parentheses; denotes statistical significance at the $1 \%$ level, at the $5 \%$ level, and at the $10 \%$ level, all for two-sided hypothesis tests. The set of Geographic Controls includes absolute latitude, longitude, mean elevation, and mean and standard deviation of average crop yield (pre-1500CE). The set of Climatic Controls includes mean and standard deviation for precipitation $(\mathrm{mm} / \mathrm{month})$ and daily mean temperature.

In Table 1 we present OLS estimates for the association between an indicator for the occurrence of non-civil conflict and the presence of historical ethnic borders in the grid cell, while accounting for a basic set of geographic and climatic characteristics that are sequentially added to our econometric specifications. In particular, column (1) shows the unconditional relationship between the prevalence 
of conflict and the presence of historical ethnic borders. The estimated coefficient is statistically significant at the 1 percent level and is consistent with an economically significant effect of the presence of historical ethnic borders. In particular, grids with a historical ethnic border are 13.7 percentage points more likely to have at least one conflict during our period of analysis (i.e., 1997-2014). In column 2 we add country fixed effects to account for time-invariant and country-specific factors, such as national institutions, that may affect the prevalence of conflict. Indeed, accounting for country fixed effects captures differences across countries in "average" geographic, institutional and cultural characteristics, and thus alleviates concerns due to omitted variables. The addition of this set of fixed effects improves the precision of the estimation of our parameter of interest as evidenced by the decrease in estimated standard errors. However, it is important to note that if the historical ethnic border indicator is mismeasured, the introduction of fixed effects may exacerbate attenuation bias. ${ }^{26}$ Indeed, this is consistent with the reduction of the point estimate for the presence of historical ethnic borders as observed in column 2. Next, in column 3, we account for ethnicity fixed effects and find similar results. Notably, our indicator of historical ethnic border presence and the set of fixed effects explain one third of the total variation in the prevalence of conflict.

In column 4 we add a set of basic geographical controls that potentially correlate with two key drivers of conflict, namely ethnic diversity and population density (Michalopoulos, 2012; DepetrisChauvin and Özak, 2018), as well as with the likelihood of having a historical ethnic border. These geographic controls are longitude, absolute latitude (which is known to correlate positively with measures of diversity), elevation (negatively correlated with diversity and population density) and the mean and standard deviation of crop yield -pre-1500 CE- (which are positively correlated to both population density and diversity). The addition of this set of controls does not qualitatively affect previous results.

In column 5 of Table 1 we add the means and standard deviations of precipitation and temperature, which have also been found to correlate with diversity and population density (Moore et al., 2002; Nettle, 1998). The estimated coefficient remains statistically significant at the 1 percent level. After accounting for all these controls, grids with a historical ethnic border are 7.3 percentage points more likely to have at least one conflict during our period of analysis.

Finally, in columns 6,7 , and 8 we use three alternative dependent variables accounting for the intensive margin of conflict during our period of analysis: the log-number of conflict events (column 6 ), the fraction of years with at least one conflict event (column 7), and the log-number of casualties associated with these events (column 8). ${ }^{27}$ Regardless of the dependent variable used, we find that the prevalence of historical ethnic borders is a strong and statistically significant predictor of conflict. The presence of a historical border is associated with an increase in the number of conflict events and fatalities of almost 13 and 7 percent, respectively. Further, historical ethnic borders are associated with an increase of roughly 1.2 percentage points in the incidence of conflict (measured as the fraction of years with at least one conflict) which represents approximately an additional half a year of conflict

\footnotetext{
${ }^{26}$ It can be shown that if the measurement error is uncorrelated within countries or ethnic homelands, including fixed effects to the model might increase the variance of the measurement error while reducing the variance of the signal, thus worsening the original attenuation bias.

${ }^{27} \mathrm{Log}$-transforming the dependent variable facilitates the interpretation of the point estimates for prevalence of ethnic borders as standard semi-elasticities.
} 
in the sample period.

We also explore the relation between intensive measures of exposure to historical ethnic borders and conflict. In particular, in Table C.1 we study the prevalence of conflict, accounting for the full set of controls, but replacing the measure of the extensive margin of historical ethnic borders for two measures of its intensive margin in each grid: total length of historical ethnic borders and total number of historical ethnic borders (both variable in logs). We find that the two measures of intensity of borders are strongly and statistically associated with an increase in the prevalence of conflict. Specifically, if border length is doubled (e.g., $42 \mathrm{kms}$ over the mean value of border length) the probability of conflict increases 2 percent (column 2). Further, an additional ethnic border over its mean value is associated with a 10 percent increase in the probability of conflict (column 3). Moreover, our measure of prevalence of ethnic borders and the two measures of intensity explain the exact same amount of variation (i.e, 34 percent) in conflict prevalence as reflected by the adjusted R-squared. Additionally, Table C.2 replicates the last three columns of Table 1 using our two measures of the intensive margin of the historical ethnic borders. Both the total length and the number of historical ethnic borders are strong and statistically significant predictors of all measures of the intensity of conflict. Finally, in Table C.3 we replicate the analysis of Table 1 using an alternative source for ethnic borders. Specifically, we use the ethnic borders from GREG (Weidmann et al., 2010), which depict the location of homelands circa 1960. Reassuringly, we obtain qualitatively similar results.

\subsubsection{Placebo: Random Allocation of Ethnic Borders Status (OLS)}

One may be concerned that our results are simply reflecting the high prevalence of both ethnic borders and conflict across Africa. In particular, given the high prevalence of conflict across the African continent, as well as the high number of ethnicities, and thus ethnic borders, the positive association between borders and conflict may arise by pure chance. In order to mitigate this potential concern, we undertake a simple placebo test.

In our placebo test we randomly re-allocate historical ethnic border status across grid cells. Specifically, we randomly assign ethnic border status to each grid cell, ensuring that we match the mean and standard deviation of the actual distribution of prevalence of historical ethnic borders across Africa. We then re-estimate our main specification (i.e., column 5 in Table 1) using the randomly assigned border status as main independent variable. We repeat this procedure 10,000 times. Additionally, we repeat this placebo analysis imposing a more restrictive spatial structure: we ensure that our randomization matches the mean and standard deviation of the actual distribution of prevalence of historical ethnic borders within each country in our sample.

Figure 5(a) depicts the distributions of point estimates underlying the two aforementioned randomization methods as well as the estimated coefficient obtained in column 5 of Table 1 (depicted as the red vertical line in the figure). Regardless of the randomization method used, all the estimated coefficients for the fake border status are centered around zero and distributed far from our baseline estimate. As shown in Figures 5(b)-5(d) we obtain similar results for the other grid cell sizes analyzed in the paper. Thus, this placebo test suggests that our results are not driven by the high prevalence of both ethnic borders and conflict, but due to the deeper spatial structure of historical ethnic borders. 


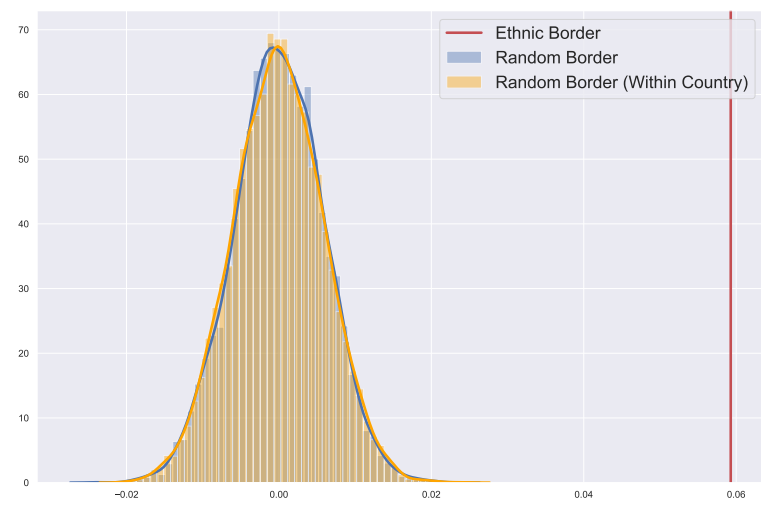

(a) Cell Size $50 \times 50$

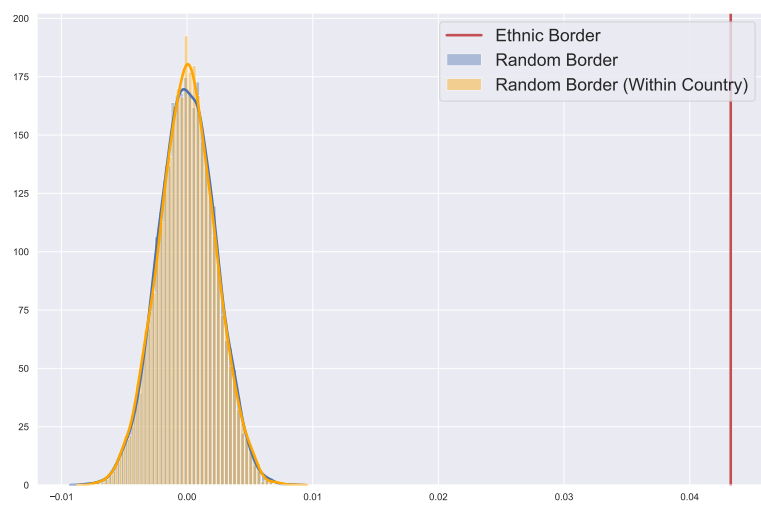

(c) Cell Size $25 \times 25$

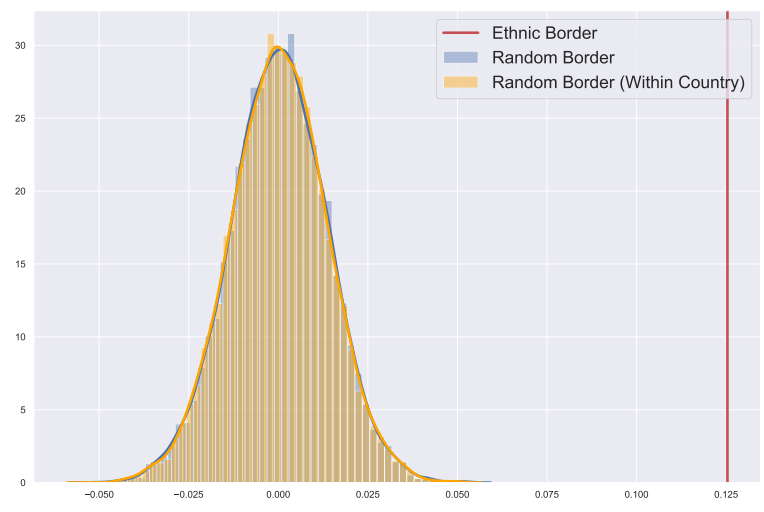

(b) Cell Size $100 \times 100$

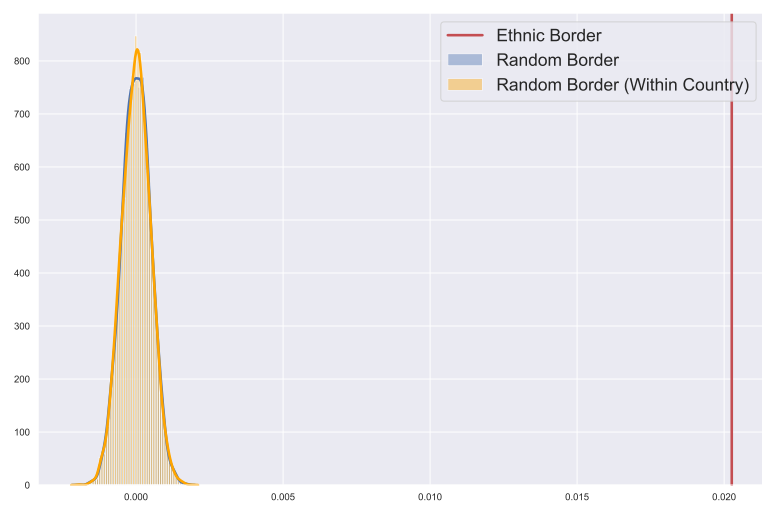

(d) Cell Size $10 \times 10$

Figure 5: Placebo Test: Ethnic vs. Random Border Status

The vertical lines in the figure also serve as evidence that our results do not depend on the size of the grid chosen for the analysis.

Finally, to complement our placebo tests, Table C.6 explores the robustness of the analysis to exclusion of regions with low population and ethnic density (e.g., the Magreb), as well as countries with a large number of ethnicities (e.g., Nigeria) and conflict (eg., Somalia). Reassuringly, the results remain qualitatively unchanged.

\subsection{Results}

While the previous results are consistent with a positive impact of historical ethnic borders on contemporary conflict, the estimated coefficients might be biased. Indeed, historical ethnic borders are unlikely to be randomly assigned, while Murdock's map may contain non-trivial measurement error. To alleviate these concerns, we employ the theory-based instrumental variable strategy introduced in sections 3.3 and 3.4. In this section we present the instrumental variables estimates of our main results.

First, we establish that our instrument is a strong predictor of actual historical ethnic borders. Indeed, in Table 2 we explore the statistical relationship between the presence of a Voronoi border and the presence of a historical ethnic border under different econometric specifications. In column 1 
Table 2: Murdock's Ethnic Borders and Voronoi Ethnic Borders Instrumental Variable Analysis (First-Stage)

\begin{tabular}{llllll}
\hline \hline & \multicolumn{5}{c}{ Presence of Ethnic Border } \\
\cline { 2 - 6 } & \multicolumn{1}{c}{$(1)$} & $(2)$ & $(3)$ & $(4)$ & $(5)$ \\
\hline Presence of Voronoi Border & $0.326^{* * *}$ & $0.273^{* * *}$ & $0.125^{* * *}$ & $0.111^{* * *}$ & $0.107^{* * *}$ \\
& $(0.018)$ & $(0.019)$ & $(0.021)$ & $(0.019)$ & $(0.018)$ \\
\hline Country FE & No & Yes & Yes & Yes & Yes \\
Ethnic FE & No & No & Yes & Yes & Yes \\
Geographic Controls & No & No & No & Yes & Yes \\
Climatic Controls & No & No & No & No & Yes \\
Adjusted- $R^{2}$ & 0.11 & 0.15 & 0.68 & 0.70 & 0.71 \\
Observations & 14078 & 14078 & 14078 & 14078 & 14078 \\
\hline
\end{tabular}

Notes: Heteroskedasticity robust standard error estimates clustered at the country-level are reported in parentheses; ${ }^{* * *}$ denotes statistical significance at the $1 \%$ level, $* *$ at the $5 \%$ level, and * at the $10 \%$ level, all for two-sided hypothesis tests. The sets of Geographic and Climatic controls are described in Table 1.

we show that a grid intersected by at least one Voronoi border is, unconditionally, 32 percent more likely to host an actual historical ethnic border. This association is strongly statistically significant as reflected by a First-Stage F-statistic of 196. The predictive power of Voronoi borders remains strong and statistically significant as we sequentially add country fixed effects (column 2), ethnicity fixed effects (column 3) and the expanded set of geographical and climatic controls in columns 4 and 5. The First-Stage F-statistic for the specification with the full set of controls remains remarkably high. Moreover, once we control for country and ethnicity fixed effects, the point estimate for the presence of a Voronoi border remains virtually unaltered as we add different geographic and climatic controls. This suggests that once we control for unobserved country and ethnic characteristics our instrument is nearly orthogonal to geographic and climatic characteristics of the grid cell, as proposed in section 3.4 and predicted by our theory. ${ }^{28}$

In Table 3 we present our main results where we instrument the potentially endogenous presence of historical ethnic borders based on Murdock's map with the presence of Voronoi borders based on centroids. First, columns 1 and 2 present the results for the prevalence of conflict as we add different set of controls. Column 1 accounts only for country and ethnicity fixed effects, while column 2 additionally accounts for the set of geographical and climatic controls. ${ }^{29}$ The estimated coefficient in both columns is basically identical, providing further support to the view that the location of Voronoi borders is mostly orthogonal to cell-level characteristics. Second, columns 3, 4, and 5 show the results for the 3 measures of intensity of conflict (the number of conflict events, fraction of years with at least one conflict, and

\footnotetext{
${ }^{28}$ In Table C.7 we estimate all possible combinations for the first-stage by permuting our three measures of prevalence and intensity of historical ethnic borders as well as their three counterparts based on Voronoi borders. All specifications in Table C.7 account for the full set of controls as before. Tables C.8 and C.9 replicate the analysis of Table 2 using the number and total length of Voronoi borders as predictors of the presence of historical ethnic borders, respectively. We find that our two measures of the intensive margin of Voronoi borders are indeed strong and statistically significant predictors of the presence of historical ethnic borders based on the Murdock's map.

${ }^{29}$ Table C.10 replicates the full set of regressions of Table 1.
} 
Table 3: Historical Ethnic Borders and Conflict (IV)

\begin{tabular}{|c|c|c|c|c|c|c|c|}
\hline & \multicolumn{7}{|c|}{ Conflict } \\
\hline & \multirow{2}{*}{\multicolumn{2}{|c|}{$\begin{array}{c}\text { Prevalence } \\
\text { Presence }\end{array}$}} & \multicolumn{3}{|c|}{ Intensity } & \multicolumn{2}{|c|}{ Onset } \\
\hline & & & Events & Years & Fatalities & Onset & Number \\
\hline & $(1)$ & $(2)$ & (3) & $(4)$ & $(5)$ & (6) & $(7)$ \\
\hline Presence of Ethnic Border & $\begin{array}{c}0.274^{* * *} \\
(0.064)\end{array}$ & $\begin{array}{c}0.273^{* * *} \\
(0.066)\end{array}$ & $\begin{array}{c}0.534^{* * *} \\
(0.136)\end{array}$ & $\begin{array}{c}0.044^{* * *} \\
(0.014)\end{array}$ & $\begin{array}{c}0.519^{* * *} \\
(0.128)\end{array}$ & $\begin{array}{c}0.079 \text { *** } \\
(0.025)\end{array}$ & $\begin{array}{c}0.075^{* * *} \\
(0.023)\end{array}$ \\
\hline Country FE & Yes & Yes & Yes & Yes & Yes & Yes & Yes \\
\hline Ethnic FE & Yes & Yes & Yes & Yes & Yes & Yes & Yes \\
\hline Main Controls & No & Yes & Yes & Yes & Yes & Yes & Yes \\
\hline First-stage F-statistic & 35.03 & 34.14 & 34.14 & 34.14 & 34.14 & 34.14 & 34.14 \\
\hline Mean Prevalence & 0.22 & 0.22 & 0.36 & 0.03 & 0.32 & 0.03 & 0.03 \\
\hline Adjusted- $R^{2}$ & 0.30 & 0.30 & 0.35 & 0.35 & 0.32 & 0.15 & 0.18 \\
\hline Observations & 14078 & 14078 & 14078 & 14078 & 14078 & 14078 & 14078 \\
\hline
\end{tabular}

Notes: Heteroskedasticity robust standard error estimates clustered at the country-level are reported in parentheses; *** denotes statistical significance at the $1 \%$ level, ** at the $5 \%$ level, and * at the $10 \%$ level, all for two-sided hypothesis tests. Main Controls refer to the sets of Geographic and Climatic controls described in Table 1.

number of conflict-related fatalities, respectively) when accounting the full set of controls. Our IV results indicate a sizable economic impact of borders: hosting a historical ethnic border increases the prevalence of conflict by 27 percentage points (column 2) which represents more than 75 percent of the mean value of prevalence of conflict in our sample. When compared with its OLS counterpart, IV point estimates are roughly four times larger. This inflation in the IV coefficient is consistent with our presumption that attenuation bias due to measurement error in our historical ethnic borders from Murdock's map was likely to be sizable. Moreover, omitted historical factors that may have codetermined the location of ethnic borders and the incentives for peaceful coexistence between ethnic groups (such as trade, inter-ethnic marriage) would also bias the OLS estimates towards zero.

The impact of historical ethnic borders on the intensity of conflict is also statistically and economically important regardless of the measure of conflict intensity we use. Indeed, the presence of a historical ethnic border increases the number of conflict events and fatalities by 53 (column 3) and 52 (column 5) percent, respectively. We also find that the presence of historical ethnic borders increases by 4.4 percentage points the fraction of years with at least one conflict (column 4), which represents almost three additional years of conflict in the sample period under analysis.

Finally, we use the UCDP-GED dataset to show that both the extensive and intensive margin of conflict onsets is strongly predicted by the presence of historical ethnic borders. Specifically, grids with historical ethnic borders are 8 percentage points more likely to be the initial location of a confrontation within a conflict dyad (column 6). This probability increase represents almost 3 times the average probability of conflict onset in our sample; suggesting a sizable economic impact of borders on the initiation of conflict. Furthermore, the number of onsets increases 7.5 percent when an ethnic border 
is present (column 7). ${ }^{30}$

\subsection{Robustness}

Our core results shown in Table 3 are robust to a battery of sensitivity checks. In this section we present several types of robustness analyses. First, we show that our results are robust to the selection of location of the central location as well as Voronoi construction. Second, we address concerns regarding inference, sampling of countries, and measurement error. Third, we show that our results are robust across conflict data sources and grid sizes used in the empirical analysis. Fourth, we also study the potential confounding effect of disease, climate, mobility and isolation as well as accessibility to water. Fifth, we show that our results are not driven by other types of borders (either geographic, ecological or administrative) that may confound with the presence of historical homeland boundaries as documented in Murdock's map. Sixth, we explore the robustness of our results to accounting for other sources of conflict, such as presence of minerals and oil, as well as historical wars. Seventh, we show that our results are not merely reflecting the potential direct impact of contemporary diversity or its geographical determinants. Finally, we perform a placebo test similar to the one performed of our OLS analysis.

\subsubsection{Instrumental Variable: Centroid Selection and Voronoi Construction}

Although the results presented so far suggest that our instrumental variable strategy is very robust, one may be concerned that the choice of central location or the method for construction of the Voronoi borders may drive the results. To explore this issue, we follow various strategies. First, we vary the choice of central location, so that instead of using the geometric centroid within the homeland (i.e., the mean latitude and longitude) based on the Murdock map, we use either (i) the core locations of ethnicities in the precolonial era as identified in the Ethnographic Atlas (Murdock, 1967) and the Atlas of Precolonial Societies (Müller, 1999), (ii) the core locations of ethnicities circa 1960 as depicted in GREG (Weidmann et al., 2010); (iii) the centroid of the cell in the homeland in the Murdock map that produces the maximum calories using only 1 crop (Galor and Özak, 2016), (iv) the centroid of the cell in the homeland that produces the maximum average calories using all available crops (Galor and Özak, 2015), or (v) the centroid of the cell in the homeland that produces the maximum total calories using all available crops (Galor and Özak, 2015).

Table 4 shows the first-stage results of using the Voronoi borders generated by these alternative central locations as an instrument for historical ethnic borders. Our main results remain qualitatively unchanged. In particular, the estimates are similar across instruments, and conditional on our set of fixed effects, additionally controlling for geography and climate has virtually no effect on them. Similarly, Table 5 compares the IV estimates based the various instrumental variables. Again, the results suggest a significant effect of historical ethnic borders on contemporary conflict. Moreover, as can be seen by comparing the results of Panels B and C, conditional on country and ethnicity fixed

\footnotetext{
${ }^{30}$ Importantly, using the intensive Voronoi border measures as an instrument generates similar results. In particular, Table C.11 replicates IV estimations of our main specification in Table 3 using the number as well as the total length of Voronoi borders as instruments for the presence of historical ethnic borders. The IV point estimates in all specifications are similar to those in Table 3.
} 
effects, accounting for geographical and climatic characteristics of a cell does not affect the estimates, further providing support for our identification strategy. ${ }^{31}$ Tables C.4 and C.5 replicate these analyses based on the ethnic borders from GREG with similar results.

Additionally, we vary how given the centroid we compute the location of Voronoi borders. In particular, instead of using geodesic distances, which assume geography and climate do not affect mobility, we employ migratory distances based on the Human Mobility Index (Özak, 2010, 2018). Reassuringly, as established in Table C.35 the results remain unchanged. ${ }^{32}$

Table 4: Murdock's Ethnic Borders and Voronoi Ethnic Borders Instrumental Variable Analysis (First-Stage)

\begin{tabular}{|c|c|c|c|c|c|c|c|}
\hline & \multicolumn{7}{|c|}{ Presence of Ethnic Border } \\
\hline & Murdock & Atlas & EA & GREG & CSI & CSIMEAN & CSITOT \\
\hline & $(1)$ & $(2)$ & $(3)$ & $(4)$ & $(5)$ & $(6)$ & $(7)$ \\
\hline \multicolumn{8}{|l|}{ Panel A: No Controls } \\
\hline Presence of Voronoi Border & $\begin{array}{c}0.326^{* * *} \\
(0.018)\end{array}$ & $\begin{array}{c}0.253^{* * *} \\
(0.017)\end{array}$ & $\begin{array}{c}0.248^{* * *} \\
(0.018)\end{array}$ & $\begin{array}{c}0.212^{* * *} \\
(0.021)\end{array}$ & $\begin{array}{c}0.207^{* * *} \\
(0.021)\end{array}$ & $\begin{array}{c}0.220 * * * \\
(0.022)\end{array}$ & $\begin{array}{c}0.220 * * * \\
(0.022)\end{array}$ \\
\hline \multicolumn{8}{|l|}{ Panel B: Fixed Effects } \\
\hline Presence of Voronoi Border & $\begin{array}{c}0.125^{* * *} \\
(0.021)\end{array}$ & $\begin{array}{c}0.110^{* * *} \\
(0.020)\end{array}$ & $\begin{array}{c}0.122^{* * *} \\
(0.023)\end{array}$ & $\begin{array}{c}0.118^{* * *} \\
(0.025)\end{array}$ & $\begin{array}{c}0.097^{* * *} \\
(0.020)\end{array}$ & $\begin{array}{c}0.099 * * * \\
(0.020)\end{array}$ & $\begin{array}{c}0.099 \text { *** } \\
(0.020)\end{array}$ \\
\hline \multicolumn{8}{|l|}{ Panel C: All Controls } \\
\hline Presence of Voronoi Border & $\begin{array}{c}0.107 * * * \\
(0.018)\end{array}$ & $\begin{array}{c}0.091^{* * *} \\
(0.017)\end{array}$ & $\begin{array}{c}0.104^{* * *} \\
(0.019)\end{array}$ & $\begin{array}{c}0.098^{* * *} \\
(0.022)\end{array}$ & $\begin{array}{c}0.078^{* * *} \\
(0.017)\end{array}$ & $\begin{array}{c}0.080 * * * \\
(0.017)\end{array}$ & $\begin{array}{c}0.080 * * * \\
(0.017)\end{array}$ \\
\hline
\end{tabular}

\subsubsection{Spatial Autocorrelation, Sampling, Measurement Error, and Cell Sizes}

One concern relates to the potential underestimation of the standard errors due to spatial autocorrelation, not fully captured by our approach of adjusting standard errors for within-country correlation in the error term. Nonetheless, our main results are robust to a non-parametric estimation of the standard errors allowing for cross-sectional spatial correlation (Conley, 1999). Indeed, in Table C.12 we report standard errors adjusted for two-dimensional spatial autocorrelation for the cases of $100 \mathrm{~km}, 200 \mathrm{~km}$, $500 \mathrm{~km}$, and $1000 \mathrm{~km}$ cut-off distances both in the OLS and IV cases (i.e., main specifications in Tables 1 and 3, respectively). ${ }^{33,34}$ For our preferred specification (i.e., IV estimates when including the full set

\footnotetext{
${ }^{31}$ Tables C.28-C.33 replicate our main Table C.33 for all the different instruments. The qualitative nature of the results does not change, although the estimated coefficients are usually larger.

${ }^{32}$ Appendix G presents additional results using these alternative instruments. In particular, it provides evidence for the effect of historical ethnic borders using two of these instruments jointly, which allows for overidentification tests.

${ }^{33}$ For the purpose of comparison, we also report in the same table the standard errors adjusted for clustering at the country level which is the standard method we follow in our main analysis.

${ }^{34}$ We thank Mathias Thoening for sharing the Stata command that allows for spatial autocorrelation adjustment in an IV setting (see Colella et al. (2018)).
} 
Table 5: Historical Ethnic Borders and Conflict (IV) Robustness to Centroid Choice

\begin{tabular}{|c|c|c|c|c|c|c|c|}
\hline & \multicolumn{7}{|c|}{ Conflict Prevalence } \\
\hline & Murdock & Atlas & EA & GREG & CSI & CSIMEAN & CSITOT \\
\hline & (1) & $(2)$ & $(3)$ & $(4)$ & $(5)$ & (6) & $(7)$ \\
\hline \multicolumn{8}{|l|}{ Panel A: No Controls } \\
\hline Presence of Ethnic Border & $\begin{array}{c}0.382^{* * *} \\
(0.066)\end{array}$ & $\begin{array}{c}0.506^{* * *} \\
(0.080)\end{array}$ & $\begin{array}{c}0.509 * * * \\
(0.087)\end{array}$ & $\begin{array}{c}0.476^{* * *} \\
(0.085)\end{array}$ & $\begin{array}{c}0.611^{* * * *} \\
(0.097)\end{array}$ & $\begin{array}{c}0.547^{* * *} \\
(0.092)\end{array}$ & $\begin{array}{c}0.547^{* * *} \\
(0.092)\end{array}$ \\
\hline \multicolumn{8}{|l|}{ Panel B: Fixed Effects } \\
\hline Presence of Ethnic Border & $\begin{array}{c}0.274^{* * *} \\
(0.064)\end{array}$ & $\begin{array}{c}0.346^{* * *} \\
(0.087)\end{array}$ & $\begin{array}{c}0.407^{* * *} \\
(0.096)\end{array}$ & $\begin{array}{c}0.216^{* *} \\
(0.091)\end{array}$ & $\begin{array}{c}0.389^{* * *} \\
(0.104)\end{array}$ & $\begin{array}{c}0.307^{* * *} \\
(0.090)\end{array}$ & $\begin{array}{c}0.307^{* * *} \\
(0.090)\end{array}$ \\
\hline \multicolumn{8}{|l|}{ Panel C: All Controls } \\
\hline Presence of Ethnic Border & $\begin{array}{c}0.273^{* * *} \\
(0.066)\end{array}$ & $\begin{array}{c}0.351^{* * *} \\
(0.100)\end{array}$ & $\begin{array}{c}0.433^{* * *} \\
(0.103)\end{array}$ & $\begin{array}{c}0.215^{* *} \\
(0.100)\end{array}$ & $\begin{array}{c}0.422^{* * *} \\
(0.123)\end{array}$ & $\begin{array}{c}0.328 * * * \\
(0.105)\end{array}$ & $\begin{array}{c}0.328^{* * *} \\
(0.105)\end{array}$ \\
\hline
\end{tabular}

Notes: Heteroskedasticity robust standard error estimates clustered at the country-level are reported in parentheses; *** denotes statistical significance at the $1 \%$ level, ${ }^{* *}$ at the $5 \%$ level, and $*$ at the $10 \%$ level, all for two-sided hypothesis tests.

of controls), we obtain the largest standard errors when adjusting by two-dimensional spatial autocorrelation up to $1000 \mathrm{~km}$. Nonetheless, these standard errors are only 10 percent larger than in the case of clustering at the country level. Moreover, as we show in Table C.13 standard errors clustered at the ethnicity-level are smaller than when clustering at the country-level. A similar result obtains if instead standard errors are two-way clustered at the country and ethnicity levels (Table C.14). In all these approaches the associated p-values are below the standard level of 0.01 . This suggests that clustering at the country level does not remarkably underestimate standard errors and represents a conservative approach for avoiding over-rejection of the null hypothesis concerning the statistical significance of the coefficient for the prevalence of historical ethnic borders.

Another potential concern is that our results may be driven by some influential observations in countries that are known to be disproportionally affected by conflict or have very low population density and few ethnic groups. To alleviate this concern we re-estimate our baseline regression dropping observations in a set of countries one at a time (Table C.15). Specifically, we drop observations in all the countries of the Magreb region, Congo DRC, Kenya, Nigeria, Sierra Leone, Somalia, and South Africa. All the point estimates in Table C.15 are virtually equal to the one for the unrestricted case. This suggests that no particular region or country is driving our core results.

Finally, in Tables F.5, F.10, and F.15 we replicate Table 3 for grid cells of sizes $100 \times 100 \mathrm{~km}$, $25 \times 25 \mathrm{~km}$, and $10 \times 10 \mathrm{~km}$ respectively; showing that our results do not depend on the grid cell size employed in our econometric analysis (see also Figure D.1). ${ }^{35}$ Moreover, since variations in cell sizes generate variations in the nature of potential measurement errors, these results suggest that our main

\footnotetext{
${ }^{35}$ Appendix F replicates our main results for all these cell sizes.
} 
findings are not driven by measurement error. ${ }^{36,37}$

\subsubsection{Conflict Data Source}

Next, we show the robustness of our result to using PRIO's Georeferenced Event dataset (UCDP-GED) to compute our four different measures of conflict prevalence and intensity studied above. Specifically, we replicate Table 3 using our measure of non-state conflict. ${ }^{38}$ The results are shown in Table C.17 and suggest that our results does not depend on the choice of the conflict data source. Furthermore, our result holds for other types of conflict such communal violence (Table C.18).

\subsubsection{Disease and Climate}

Our results are also robust to an expanded set of disease and climatic controls. In particular, the results in Table C.19 account for the mean and standard deviation of malaria suitability (Column 2), the mean and standard deviation of the suitability for tse-tse flies (Column 3), the mean and standard deviation of various additional climate controls (diurnal temporal range, vapor pressure, cloud cover, wet day frequency) (Column 4). Reassuringly, the estimated IV coefficient remains basically unchanged. Moreover, accounting for all these additional controls jointly (Column 5) does not affect the results either.

\subsubsection{Geographical Isolation and Access to Water}

One possible concern regarding the interpretation of our IV results could be that Voronoi borders were systematically predicted to be located at highly isolated regions. In this sense, since rebel groups tend to operate more easily in remote and isolated locations, we could just be capturing the effect of these characteristics on conflict instead. Nonetheless, we show in Table C.20 that our results are robust to different measures of isolation and remoteness. To do so, we compute two indicators accounting for geographic characteristics that make traversing a giving grid cell costly. Specifically, we control for terrain ruggedness (column 2) and the Human Mobility Index (HMI) from Özak (2018) (column 3). Reassuringly, our previous results are not qualitatively affected by the inclusion of these mobility indicators.

Furthermore, the inclusion of different indicators of access to water bodies as controls has basically no effect on our results. Neither the length of rivers (column 4) or coasts (column 5) nor an indicator of access to water (column 6) affects the statistical or economic significance of historical ethnic borders

\footnotetext{
${ }^{36}$ For instance changes in grid size may affect the size of the signal-to-total-variance ratio under classical measurement error. Indeed, one should expect that increases in grid size increase this ratio.

${ }^{37}$ We also provide evidence that our results are robust to the presence of non-classical measurement error. In particular, we follow the method of Black et al. (2000) to estimate improved lower bounds for the effect of historical borders in the presence of non-classical measurement error. In particular, given two measures of historical ethnic borders (Murdock and Voronoi), Black et al. (2000) show that the estimated OLS coefficient for the presence of both measures of historical ethnic borders relative to the absence of borders according to both measures provides a more precise lower bound for the true causal effect. As Black et al. (2000) show, the true effect under non-classical measurement error, due to truncation as in our setting, is bounded between this OLS estimate (Table C.36) and our IV estimate (Table 3).

${ }^{38}$ We do not replicate the analysis for onsets, as they are constructed using PRIO, since ACLED does not provide this information.
} 
for the prevalence of conflict. ${ }^{39}$ Including all the previous controls together has virtually no impact on our results. Finally, in Table C.23 we show that proximity to capitals, large cities, and the geometric centroid of the ethnic homeland does not qualitatively alter our results. This suggests that borders do not simply reflect isolated locations with low state capacity where the projection of power from the central government is weak.

\subsubsection{Rivers, Coasts, and Other Types of Borders}

When interpreting our main results regarding the relationship between historical ethnic borders and contemporary conflict, a possible source of concern is that the estimated effect of the presence of ethnic borders may be driven, at least in part, by other types of borders (either geographic, ecological or administrative) that may coincide with the historical homeland boundaries as documented in Murdock's map. Nonetheless, as we argued above, our IV identification strategy seeks to precisely exploit variation in historical ethnic border presence (as predicted by Voronoi borders) that is orthogonal to grid's characteristics such as geography and ecology. Results in Table C.21 are consistent with this view. Indeed, while the presence of rivers, coast, and ecological borders are positively correlated with the prevalence of contemporary conflict, their inclusion as controls in our main specification does not change our previous results (see columns 1 to 4 of Table C.21).

Moreover, our previous results are not qualitatively affected by the inclusion of indicators of presence of country (column 5) and sub-national administrative borders (column 6). Interestingly, these political and administrative boundaries are associated with a reduction in conflict; results that are line with the idea that "dejure" borders may increase the cost of engaging in violent disputes or may reflect an agreement that prevents conflict. We however interpret the point estimate on the presence of subnational administrative boundaries with caution, given its potential endogeneity to both conflict and the preexistence of historical ethnic borders. Finally, including all the previous set of borders does not affect our results (column 7 of Table C.21), although the estimated coefficient of the prevalence of historical ethnic borders on contemporary conflict becomes larger and remains statistically significant.

\subsubsection{Other Sources of Conflict}

We next take into account other sources of conflict highlighted in previous literature. We do so for two reasons. First, we aim to check whether our point estimates are potentially affected by the inclusion of these covariates of conflict. Second, this analysis allows us to compare the economic importance of historical ethnic borders vis-à-vis other important sources of conflict. We take into account the impact of the presence of diamonds, minerals, oil, capitals, and populated places. Figure A.5 depicts the spatial distribution of these potential sources of conflict.

Table C.22 shows that accounting for other sources of conflict does not affect our previous results. In line with previous literature these other sources of conflict are statistically significant predictors of conflict. The economic impact of hosting a historical ethnic border is more than double the magnitude associated with the presence of diamonds and minerals (columns 2 and 3). The likelihood of conflict

\footnotetext{
${ }^{39}$ Our indicator of accessibility to water accounts for the percentage of area within $100 \mathrm{kms}$ of sea, rivers, lakes, perennial and fluctuating water.
} 
due to historical ethnic borders is ten times larger than in the case of the presence of oil (column 4). On the other hand, the presence of a capital (column 5) or a populated place (column 6) are associated with a larger likelihood of contemporary conflict. This is not surprising since high population density is a key driver of conflict. In the last column of Table C.22 we include all the set of covariates together and the point estimate for the presence of historical ethnic borders remains remarkably large at $0.21 .^{40}$

\subsubsection{Historical Wars as a Potential Confounder}

As discussed above, another concern is the potential confounding effect of historical conflict. It is possible that historical ethnic conflict may have shaped the location of historical ethnic borders. Moreover, historical ethnic conflict may have persisted in a given location or may have given rise to other types of conflict that persisted in the same geographical area. Thus, one may be concerned that historical ethnic conflict is an omitted variable in our analysis. Nonetheless, the historiography of Africa indicates that pre-colonial conflict was not driven by the quest to control land but people (Herbst, 1990, 2000; Englebert et al., 2002). This suggests that historical conflict may not have occurred at ethnic borders, but in more highly populated locations. Additionally, as explained in section 3.3, the instrumental variable strategy we follow should mitigate concerns about the potential role of historical conflict. Still we explore this issue further using georefenced data on historical conflict in pre-colonial Africa (Besley and Reynal-Querol, 2014). ${ }^{41}$

In line with the narrative presented by African historiographers, we find empirical evidence consistent with the view that territorial demarcation was irrelevant in the past. Specifically, Table C.25 shows that historical ethnic borders do not correlate with the prevalence of conflict in the past (see also Table C.26). Furthermore, we find that while historical conflict strongly correlates with modern conflict (as already documented by Besley and Reynal-Querol (2014)), accounting for it in our main regressions does not affect the association between historical ethnic borders and contemporary conflict.

\subsubsection{Intra- and Inter-Ethnic Diversity}

There is a large literature claiming the positive effect of both intra- and inter-ethnic diversity on modern conflict. A potential concern is that the presence of historical ethnic borders may only reflect contemporary diversity or its geographical determinants. However, it is important to note that some of these diversity measures can be arguably endogenous to both conflict and historical ethnic borders. This possibility may difficult the interpretation of the point estimate for the prevalence of historical ethnic borders and it is precisely for this reason we were careful not to include these potentially endogenous controls in our baseline specifications. Nonetheless, as a robustness check, we next include diversity measures to assess the sensitivity of our main estimates. Further, while not conclusive, changes in our main point estimate when including these controls may shed some light on a potential

\footnotetext{
${ }^{40}$ In Table C.23 we replicate Table C.22 using measures of distances instead of indicators of the presence of other sources of conflict. We find similar results, although the estimated coefficient of historical ethnic borders is larger, namely 0.32. Noteworthy, including the distance to the nearest centroid does not qualitatively affect out results.

${ }^{41}$ Using Brecke (1999)'s conflict catalogue, Besley and Reynal-Querol (2014) identified the specific geographical location of different conflicts between African actors and between African and Non-African actors for the period 1400-1700. Brecke (1999) documents all violent conflicts in which 32 or more people died.
} 
mediating channel through which historical ethnic borders impact modern conflict. ${ }^{42}$ We explore this possibility by accounting for different measures of intra- and inter-ethnic diversity; namely the number of languages spoken in a grid and the level of ethnolinguistic fractionalization based on linguistic data (not the Murdock map). Additionally, we account for potential determinants of inter-ethnic diversity including the mean and standard deviation of agricultural suitability (Michalopoulos, 2012), and ecological diversity. Moreover, by accounting for ethnicity fixed effects we control for all ethnic level characteristics, including its level of intra-ethnic diversity (Depetris-Chauvin and Özak, 2018).

Results in Table C.24 show that all diversity measures display a positive and statistically significant association with contemporary conflict (columns 2 to 5). Nonetheless, the point estimate for the presence of historical ethnic borders remains virtually unaltered. Indeed, the estimate in column 6 suggests that the presence of a historical ethnic border increases the likelihood of modern conflict by 26 percentage points after accounting for all the diversity measures jointly (column 6). We interpret these results as strong evidence that the IV point estimate for our measure of the prevalence of historical ethnic borders is not simply reflecting the impact of diversity on contemporary conflict.

\subsubsection{Placebo: Random Allocation of Ethnic Borders Status (IV)}

As discussed in section 4.1.1, the high prevalence of both ethnic borders and conflict across Africa generates the potential concern that our results may arise by pure chance. In order to mitigate this potential concern, we employ a placebo analysis similar to the one in that section, but applied to our instrumental variable strategy. Additionally, we replicate this analysis using grid cells of different sizes.

Our strategy generalizes the placebo tests of section 4.1.1 in order to randomly re-allocate both historical ethnic border status and potential (Voronoi) border status across grid cells. Specifically, we randomly assign ethnic border status and Voronoi border status to each grid cell, ensuring that we match the mean and standard deviation of the actual distribution of prevalence of each variable across Africa (or within each country in the more restrictive approach), as well as the correlation between historical and Voronoi borders. Thus, we ensure that the joint distribution of the randomly assigned ethnic and Voronoi borders matches the joint distribution of these variables in the sample. We then reestimate our main IV specification (i.e., column 2 in Table 3) using the randomly assigned border status as main independent variable, which we instrument using the randomly assigned Voronoi border. We repeat this procedure 10,000 times. Figure D.1(a) depicts the distribution of point estimates for these 10,000 IV regressions as well as the estimated coefficient obtained in column 3 of Table 3 (depicted as the red vertical line in the figure). Reassuringly, all the estimated coefficients for the fake border status are centered around zero and distributed far from our baseline estimate. As shown in Figures D.1(b)D.1(d) we obtain similar results for the other grid cell sizes analyzed in the paper. Moreover, as Figures D.2(b)-D.2(d) show, the first-stage is equally strong in the random samples as in the actual data, as should be expected given the underlying distributional assumptions made in these simulations. As an additional test, Figures D.3(b)-D.3(d) show similar results for the reduced form regression in which

\footnotetext{
${ }^{42}$ If diversity is a mediating channel through which historical ethnic borders affect modern conflict, we should expect to observe two empirical patterns: first, there should be a positive relationship between diversity and historical ethnic borders; and second, the effect of historical borders on conflict should become smaller once accounting for the influence of diversity on conflict.
} 
conflict is associated with the random instrument. Reassuringly, the distribution of these reduced form coefficients for the random instruments is also centered around zero, while the reduced form coefficient of the Voronoi borders remains large, positive and statistically significant. Thus, these placebo tests suggest that our results are not driven by the high prevalence of both ethnic borders and conflict, but due to some deeper force due to the spatial structure of ethnic borders.

\section{Mechanisms}

In the previous sections we have documented a strong statistically and economically significant association between the presence of historical ethnic borders and the prevalence, incidence and onset of contemporary non-civil conflict in Africa. While we have strived to show that the estimated coefficient can be given a causal interpretation, we have not yet shown why or how historical ethnic borders cause conflict. This section presents evidence for the hypothesized causal role of historical ethnic borders on contemporary conflict. First we explore whether the presence of valuable resources at the border, especially land suitable for agriculture, generates differential effects of historical ethnic borders. Our results suggest that historical borders located close to productive land are more prone to conflict. Second, we explore the differential effect of historical ethnic borders on various types of conflict. We find that historical ethnic borders have a larger impact on local conflict, especially those driven by disputes over territory and authority. These results suggest that the effect of historical ethnic borders may be driven by competition over resources located close to them. In line with the idea that similar ethnic groups (either in subsistence strategies or culture) compete more intensely for resources, we find that borders at which more similar groups are in contact to have more conflict. Moreover, competition for resources results in lower landownership close to the border, especially among recent migrants to the border. Finally, we explore whether geographical or jurisdictional characteristics of historical ethnic borders matter for conflict. We show that locations with "harder" (i.e., better defined, delineated or demarcated) historical ethnic borders have less conflict.

\subsection{Borders and Resources}

We next analyze whether the presence of different resources at historical ethnic borders influences the prevalence of modern conflict (Table 6). In order to capture very local resource availability at the border and differentiate it from the characteristics of the cell in which the border is located, for we compute the presence or mean value within a $2.5 \mathrm{~km}$-buffer around the historical ethnic border. As usual, in column 1 we show our preferred specification for reference. In column 2 we explore how the suitability of land for agriculture at the border, as measured by the average potential number of calories that could be produced by different crops, affect the prevalence of conflict. The results suggest that both historical ethnic borders and higher levels of caloric suitability positively impact the prevalence of contemporary conflict. Moreover, the impact on conflict is even larger if the territory surrounding the historical ethnic border is more suitable for agriculture (i.e., high levels of the caloric suitability index). These results support the view that competition over productive land is a key mechanism underlying the strong positive impact of historical ethnic borders on modern conflict. 
Table 6: Historical Ethnic Borders and Conflict (IV)

Resources at the Border

\begin{tabular}{|c|c|c|c|c|c|c|}
\hline & \multicolumn{6}{|c|}{ Prevalence of Conflict } \\
\hline & Main & CSI & Diamonds & Minerals & Oil & Cities \\
\hline & (1) & $(2)$ & $(3)$ & (4) & $(5)$ & (6) \\
\hline \multirow[t]{2}{*}{ Presence of Ethnic Border } & $0.273^{* * *}$ & $0.271^{* * *}$ & $0.268^{* * *}$ & $0.245^{* * *}$ & $0.267^{* * *}$ & $0.212^{* * *}$ \\
\hline & $(0.066)$ & $(0.066)$ & $(0.067)$ & $(0.067)$ & $(0.070)$ & $(0.069)$ \\
\hline \multirow[t]{2}{*}{ Characteristic at Border } & & $0.052^{* * *}$ & -0.163 & $0.190 * *$ & 0.071 & 0.018 \\
\hline & & $(0.016)$ & $(0.296)$ & $(0.084)$ & $(0.110)$ & $(0.082)$ \\
\hline \multirow[t]{2}{*}{ Characteristic in Cell } & & 0.025 & $0.125^{* * *}$ & $0.110^{* * *}$ & -0.016 & $0.393^{* * *}$ \\
\hline & & $(0.017)$ & $(0.041)$ & $(0.023)$ & $(0.029)$ & $(0.033)$ \\
\hline Country FE & Yes & Yes & Yes & Yes & Yes & Yes \\
\hline Ethnic FE & Yes & Yes & Yes & Yes & Yes & Yes \\
\hline Main Controls & Yes & Yes & Yes & Yes & Yes & Yes \\
\hline First-stage F-statistic & 34.14 & 16.98 & 17.30 & 17.26 & 17.89 & 17.32 \\
\hline Adjusted- $R^{2}$ & 0.30 & 0.30 & 0.30 & 0.31 & 0.30 & 0.38 \\
\hline Observations & 14078 & 14078 & 14078 & 14078 & 14078 & 14078 \\
\hline
\end{tabular}

Notes: Heteroskedasticity robust standard error estimates clustered at the country-level are reported in parentheses; *** denotes statistical significance at the $1 \%$ level, $* *$ at the $5 \%$ level, and * at the $10 \%$ level, all for two-sided hypothesis tests. Main Controls refer to the sets of Geographic and Climatic controls described in Table 1. CSI is a measure of potential caloric suitability of agricultural land introduced by Galor and Özak (2015) and Galor and Özak (2016).

Next we explore the role of the presence of natural resources at the border. In particular, we study whether the presence at the border of diamonds (column 3), minerals (column 4) or oil (column 5) affects the prevalence of conflict. The results suggest that although the presence of natural resources in a cell tends to increase the prevalence of conflict in the cell, their presence at the border does not seem to affect the prevalence of conflict. These results may be driven in part by the low prevalence of natural resources in the small buffer around the border used to identify local conditions at the border.

Finally, we explore whether the presence of cities in the proximity of a historical ethnic borders (column 6) affects conflict. Interestingly, we do not find a significant heterogeneous effect of the presence of cities, although the presence of cities does positively correlate with conflict. The absence of an economically meaningful effect of the presence of cities at the border may be masking two opposite effects. On the one hand, cities proxy for population density, which is a well-known predictor of conflict. On the other, cities also proxy for existence of institutions or other social mechanism that may help prevent conflict. Furthermore, a population settlement near a historical ethnic border may better reflect which group is more likely to be indigenous to a particular homeland thus providing some legitimacy to the ownership of the land.

\subsection{Types of Conflict: Local, Ethnic, and Land-related Conflict}

We further take advantage of the richness of the available conflict datasets to explore what types of conflict are more likely to be present in the proximity of historical ethnic borders. As mentioned above, 
we expect historical borders to play a more fundamental role in conflicts with no clear interference of national governments, e.g. non-civil and local conflicts. Thus, we compute measures of prevalence of conflict across additional types of conflict: local and ethnic conflict. Table 7 replicates our analysis for these various types of conflict. Column 1 replicates our main result, which is based on all non-civil conflict events. Additionally, columns 2 and 3 show that both local conflicts (for which both actors in the conflict are geographically local and/or ethnically local groups) and ethnic conflict (as coded in Depetris-Chauvin et al. (2020)) are more likely to occur in the proximity of historical ethnic borders. Importantly, the results suggest that the impact of historical ethnic borders is relatively larger on local and ethnic conflicts compared to all types of non-civil conflict. Specifically, the increase in ethnic conflict due to the presence of historical ethnic borders (i.e., 13 percentage points) roughly doubles the mean prevalence of ethnic conflict.

Table 7: Historical Ethnic Borders and Conflict (IV)

Effect on Conflict Type \& Cause

\begin{tabular}{|c|c|c|c|c|c|c|c|c|}
\hline & \multicolumn{8}{|c|}{ Prevalence of Conflict } \\
\hline & $\begin{array}{l}\text { Non- } \\
\text { Civil }\end{array}$ & Local & Ethnic & Land & $\begin{array}{l}\text { Terri- } \\
\text { tory }\end{array}$ & $\begin{array}{c}\text { Au- } \\
\text { thority }\end{array}$ & $\begin{array}{c}\text { Border } \\
\& \text { Terri- } \\
\text { torial }\end{array}$ & $\begin{array}{c}\text { Religi- } \\
\text { ous }\end{array}$ \\
\hline & $(1)$ & $(2)$ & $(3)$ & $(4)$ & $(5)$ & $(6)$ & $(7)$ & $(8)$ \\
\hline Presence of Ethnic Border & $\begin{array}{l}0.273^{* * *} \\
(0.066)\end{array}$ & $\begin{array}{l}0.194^{* * *} \\
(0.066)\end{array}$ & $\begin{array}{l}0.130 * * * \\
(0.049)\end{array}$ & $\begin{array}{l}0.046^{* *} \\
(0.020)\end{array}$ & $\begin{array}{l}0.065^{*} \\
(0.039)\end{array}$ & $\begin{array}{l}0.044^{*} \\
(0.023)\end{array}$ & $\begin{array}{l}0.071^{* * *} \\
(0.027)\end{array}$ & $\begin{array}{l}-0.001 \\
(0.005)\end{array}$ \\
\hline Country FE & Yes & Yes & Yes & Yes & Yes & Yes & Yes & Yes \\
\hline Ethnic FE & Yes & Yes & Yes & Yes & Yes & Yes & Yes & Yes \\
\hline Main Controls & Yes & Yes & Yes & Yes & Yes & Yes & Yes & Yes \\
\hline First-stage F-statistic & 34.14 & 34.14 & 34.14 & 34.14 & 16.34 & 16.34 & 16.34 & 16.34 \\
\hline Mean Prevalence & 0.22 & 0.16 & 0.07 & 0.03 & 0.04 & 0.02 & 0.03 & 0.01 \\
\hline Adjusted- $R^{2}$ & 0.30 & 0.28 & 0.28 & 0.17 & 0.31 & 0.34 & 0.31 & 0.41 \\
\hline Observations & 14078 & 14078 & 14078 & 14078 & 9973 & 9973 & 9973 & 9973 \\
\hline
\end{tabular}

Notes: Heteroskedasticity robust standard error estimates clustered at the country-level are reported in parentheses; $* * *$ denotes statistical significance at the $1 \%$ level, ** at the $5 \%$ level, and $*$ at the $10 \%$ level, all for two-sided hypothesis tests. Main Controls refer to the sets of Geographic and Climatic controls described in Table 1.

\subsection{Causes of Conflict}

Next we explore the underlying causes of conflict in two ways. First, we code conflict from ACLED as land-related conflict. Second, we use data from the UCDP Non-state Conflict Issues and Actors Dataset. This dataset identifies for a subset of conflicts from the UCDP PRIO dataset the causes of the conflict. The data includes only conflicts in the period 1989-2011 and we focus on those conflicts which do not include the government nor any type of organized group. These so called communal conflicts are very local in their nature and thus may allow us to better understand the role of historical ethnic borders. Although this category of conflict is more restricted and presents a substantially smaller prevalence in our sample (only 5 percent of our grids experienced at least one these conflict events), 
this dataset allows us to distinguish between conflict issues related to land, especially territory and authority, and other issues. The data identifies (i) authority conflict between groups when there are competing claims over who exerts control through the state apparatus or informal power structures; (ii) territorial conflict related to the control or use of the land, but not authority over other warring faction. Moreover, the data identifies two additional subcategories of causes of conflict, namely borders and territorial disputes and religion.

Columns 4-8 in Table 7 explore the link between historical ethnic borders and these various causes of conflict. The results suggest that both conflict over land (column 4), territories (column 5) and authority (column 6) are more likely to emerge in the proximity of historical ethnic borders. Moreover, conflict about borders (Column 7) is 7 percentage points more likely to occur when a historical ethnic border is present. It is important to note that the estimated impact of historical borders on these type of conflicts if 50-100\% larger than their mean prevalence. Interestingly, we find that conflict about religious issues does not seem to be linked to the presence of historical ethnic borders (column 8).

\subsection{Population Pressure}

While relatively low population density and land abundance characterized Africa in pre-colonial times (Herbst, 2000; Englebert et al., 2002; Austin, 2008), things dramatically shifted due to its late demographic transition, which did not start before the mid 20th century (Livi Bacci, 1997). This high population growth in the $20^{\text {th }}$ century, coupled with low urbanization rates and an active rural-rural migration, as well as the limited amount of land, created land shortage problems in rural areas (Herbst, 1990). In fact, it has been argued that increasing pressure over land due to high population growth underlied large violent conflicts such as Darfur and Rwanda (André and Platteau, 1998; Faris, 2009).

We next analyze the potential role of population pressure at historical ethnic borders. To do so, we use the grid level data on population from HYDE (Klein Goldewijk et al., 2011) for various years to compute levels and growth of population densities across time. In particular, in Table 8, we explore the effect of historical ethnic borders and population growth on non-civil, local, ethnic, land-related, and border \& territory conflicts. In all columns we now also account for the level of population density in 1960, as well as the growth in population density between 1960 and 2005. The results suggest that historical ethnic borders that experienced a larger increase in population density have also experienced a higher prevalence of conflict. Importantly, as shown in Table C.37 it is the recent growth in population density that drives this result. Indeed, population density growth at the border between 1800 and 1900 does not seem to generate more conflict, and it is only growth post-1950 that seems to increase conflict prevalence. While we acknowledge the limitations of these historical population figures (especially pre1950) as well as the potential endogeneity of population growth to conflict and ethnic border status, the results echo Herbst (1990)'s narrative on scarcity of land in rural areas being a contemporaneous issue. $^{43}$

\footnotetext{
${ }^{43}$ In Herbst (1990)'s words "Due to high population growth and the low carrying capacity of much of the land in Africa, there are now far fewer empty areas into which people can move [...] The land frontier has all but closed. The specter of a land shortage is a dramatic development because as late as two generations ago Africa was characterized by small concentrations of people surrounded by large amounts of open land."
} 
Table 8: Historical Ethnic Borders and Conflict (IV)

Heterogeneous Effect: Growth in Population Density (1960-2005)

\begin{tabular}{|c|c|c|c|c|c|}
\hline & \multicolumn{5}{|c|}{ Prevalence of Conflict } \\
\hline & Non-Civil & Local & Ethnic & Land & $\begin{array}{c}\text { Border } \\
\& \text { Terri- } \\
\text { torial }\end{array}$ \\
\hline & $(1)$ & $(2)$ & $(3)$ & $(4)$ & $(5)$ \\
\hline Presence of Ethnic Border & $\begin{array}{l}0.240^{* * *} \\
(0.071)\end{array}$ & $\begin{array}{l}0.164^{* *} \\
(0.065)\end{array}$ & $\begin{array}{l}0.118^{* *} \\
(0.047)\end{array}$ & $\begin{array}{l}0.035^{*} \\
(0.021)\end{array}$ & $\begin{array}{l}0.067^{* *} \\
(0.026)\end{array}$ \\
\hline Growth Population Density at Border & $\begin{array}{l}0.080^{* * *} \\
(0.031)\end{array}$ & $\begin{array}{l}0.075^{* *} \\
(0.030)\end{array}$ & $\begin{array}{l}0.031^{* *} \\
(0.015)\end{array}$ & $\begin{array}{l}0.029^{* * *} \\
(0.011)\end{array}$ & $\begin{array}{l}0.014^{*} \\
(0.008)\end{array}$ \\
\hline Growth Population Density & $\begin{array}{l}0.010 \\
(0.010)\end{array}$ & $\begin{array}{l}0.007 \\
(0.009)\end{array}$ & $\begin{array}{l}-0.000 \\
(0.004)\end{array}$ & $\begin{array}{l}-0.002 \\
(0.003)\end{array}$ & $\begin{array}{l}-0.003 \\
(0.002)\end{array}$ \\
\hline Log[Population Density 1960] & $\begin{array}{l}0.094^{* * *} \\
(0.012)\end{array}$ & $\begin{array}{l}0.085^{* * *} \\
(0.012)\end{array}$ & $\begin{array}{l}0.039^{* * *} \\
(0.007)\end{array}$ & $\begin{array}{l}0.024^{* * *} \\
(0.005)\end{array}$ & $\begin{array}{l}0.005 \\
(0.004)\end{array}$ \\
\hline Country FE & Yes & Yes & Yes & Yes & Yes \\
\hline Ethnic FE & Yes & Yes & Yes & Yes & Yes \\
\hline Main Controls & Yes & Yes & Yes & Yes & Yes \\
\hline First-stage F-statistic & 11.98 & 11.98 & 11.98 & 11.98 & 6.08 \\
\hline Mean Prevalence & 0.22 & 0.16 & 0.07 & 0.03 & 0.03 \\
\hline Adjusted- $R^{2}$ & 0.32 & 0.30 & 0.29 & 0.18 & 0.31 \\
\hline Observations & 14078 & 14078 & 14078 & 14078 & 9973 \\
\hline
\end{tabular}

Notes: Heteroskedasticity robust standard error estimates clustered at the country-level are reported in parentheses; ${ }^{* * *}$ denotes statistical significance at the $1 \%$ level, $* *$ at the $5 \%$ level, and * at the $10 \%$ level, all for two-sided hypothesis tests. Growth in Population Density is computed for the period 1960-2005. Main Controls refer to the sets of Geographic and Climatic controls described in Table 1.

\subsection{Cultural and Linguistic Differences at the Border}

Given our previous results, which suggest that competition for agricultural resources and territory in newly populated areas have been conducive to conflict at ethnic borders, it is feasible that ethnic similarity at the border, either in subsistence strategies or culture, may affect the prevalence of conflict. In fact, previous literature has focused on the role of heterogeneity and relatedness between groups and emphasized the importance of shared interests and preferences to understand the role of economic and cultural similarities in conflict (Alesina et al., 2003; Alesina and La Ferrara, 2005; Spolaore and Wacziarg, 2009). On the one hand, it has been suggested that closely related groups, which tend to have similar preferences over rival goods (e.g., land), will be more likely to fight over those types of goods. On the other hand, it has been suggested that dissimilar groups, which tend to have different preferences over public goods (e.g., policies or public goods in general), will be more likely to fight over those types of goods.

To explore the role of ethnic similarities and complementarities in both cultural and economic traits across the historical ethnic borders, we match ethnicities in Murdock's map with the Ethnographic Atlas (Murdock, 1967) and information from the Ethnologue (Lewis et al., 2009) to compute several 
Table 9: Historical Ethnic Borders and Conflict (IV) Effect of Cultural Distances

\begin{tabular}{|c|c|c|c|c|c|c|c|}
\hline & \multicolumn{7}{|c|}{ Prevalence of Conflict } \\
\hline & (1) & $(2)$ & $(3)$ & $(4)$ & $(5)$ & $(6)$ & $(7)$ \\
\hline Presence of Ethnic Border & $\begin{array}{l}0.347^{* * *} \\
(0.063)\end{array}$ & $\begin{array}{l}0.351^{* * *} \\
(0.065)\end{array}$ & $\begin{array}{l}0.339 * * * \\
(0.063)\end{array}$ & $\begin{array}{l}0.273^{* * *} \\
(0.072)\end{array}$ & $\begin{array}{l}0.281^{* * *} \\
(0.076)\end{array}$ & $\begin{array}{l}0.354^{* * *} \\
(0.069)\end{array}$ & $\begin{array}{l}0.349^{* * *} \\
(0.067)\end{array}$ \\
\hline Subsistence Distance (Ordinal) & & $\begin{array}{l}-0.095^{* * *} \\
(0.023)\end{array}$ & & & & & \\
\hline Subsistence Distance (Cardinal) & & & $\begin{array}{l}-0.064^{* * *} \\
(0.020)\end{array}$ & & & & \\
\hline Linguistic Distance (Level 6) & & & & $\begin{array}{l}-0.033^{* *} \\
(0.016)\end{array}$ & & & \\
\hline Linguistic Distance (Level 15) & & & & & $\begin{array}{l}-0.066^{* * *} \\
(0.025)\end{array}$ & & \\
\hline Cultural Distance (All) & & & & & & $\begin{array}{l}-0.120^{* * *} \\
(0.031)\end{array}$ & \\
\hline Cultural Distance (All85) & & & & & & & $\begin{array}{l}-0.115^{* * *} \\
(0.030)\end{array}$ \\
\hline Country FE & Yes & Yes & Yes & Yes & Yes & Yes & Yes \\
\hline Ethnic FE & Yes & Yes & Yes & Yes & Yes & Yes & Yes \\
\hline Main Controls & Yes & Yes & Yes & Yes & Yes & Yes & Yes \\
\hline First-stage F-statistic & 28.51 & 28.45 & 27.63 & 23.84 & 22.86 & 26.44 & 27.42 \\
\hline Adjusted- $R^{2}$ & 0.30 & 0.31 & 0.30 & 0.32 & 0.33 & 0.31 & 0.31 \\
\hline Observations & 8127 & 8127 & 8127 & 10130 & 10130 & 8127 & 8127 \\
\hline
\end{tabular}

Notes: Heteroskedasticity robust standard error estimates clustered at the country-level are reported in parentheses; *** denotes statistical significance at the $1 \%$ level, $* *$ at the $5 \%$ level, and $*$ at the $10 \%$ level, all for two-sided hypothesis tests. Main Controls refer to the sets of Geographic and Climatic controls described in Table 1. See main text for discussion on construction of distance measures.

measures of economic, cultural, and linguistic distances across the historical ethnic border. Specifically, we compute measures of similarity in subsistence strategy, linguistic distances for various levels of aggregation of the language tree coded in Ethnologue, as well as cultural distances based on the Ethnographic Atlas. ${ }^{44,45,46}$ The results of the analysis are shown in Table 9 and suggest that the larger the ethnic differences at the border, the less conflict there is. In particular, the larger the differences in economic subsistence strategy between ethnicities at the border, the lower the probability of conflict. ${ }^{47}$ In other words, if two ethnic groups across the border rely on a similar type of economic subsistence

\footnotetext{
${ }^{44}$ We employ variables v1-v5 in the Ethnographic Atlas, which provide measures of the share of subsistence coming from hunting, gathering, fishing, herding and agriculture. We compute cosine distances based on the ordinal levels of all these variables (Subsistence Column 1 in Table 9), as well as pairwise Euclidean distances based on the cardinal levels of all these variables (Subsistence Column 2).

${ }^{45} \mathrm{We}$ follow the literature and compute linguistic distances as the share of non-common nodes in the language tree (Fearon, 2003).

${ }^{46}$ We compute two measures based on all variables in the Ethnographic Atlas. The first employs all questions, including question with no data, where we treat missing data as a category in itself. The second employs only variables where at least $85 \%$ of the ethnicities have data. We compute cosine distances based on the answer categories of all these variables.

${ }^{47}$ In each cell we employ the mean cultural distance across borders.
} 
strategy (e.g., agriculture), they will be more likely to fight. In columns 4 to 7 we employ different measures of cultural and linguistic distances and obtain similar results. Moreover, as shown in Tables C.38-C.41, the results are robust to the specific measures employed or whether we constrain the analysis to cells within $250 \mathrm{kms}$ of borders. The pattern in the data is clear and suggests that the more alike two groups are, the higher the probability of conflict at the border.

\subsection{Proximity to Ethnic Borders and Individual Land Ownership}

In this section we explore whether the pattern of landownership differs close to the border. Our results suggest that conflict is more prevalent in borders with larger recent population pressures, driving especially territorial conflict. Thus, we may expect lower prevalence of land ownership close to the border. To explore this issue, we use data from several waves of the Demographic and Health Survey (DHS) in 33 countries. These surveys provide georeferenced location data for respondents which allows us to compute the distance of each respondent to the closest historical border, as well as the geographical characteristics of her location. Importantly, we are able to assign each respondent to a historical ethnic homeland. Among the data collected in these surveys, the respondents were asked whether they owned land. Moreover, in most cases, individuals report their ethnic affiliation. In order to analyze how proximity to historical ethnic borders impact land ownership we estimate different versions of the following equation:

$$
\text { Ownership } i_{i, e, w, l(h, c)}=\alpha+\beta \text { Distance }_{l}+\gamma^{\prime} X_{i}+\delta^{\prime} G_{l}+\Phi_{e}+\Theta_{h}+\Omega_{w}+\Pi_{c}+\epsilon_{h},
$$

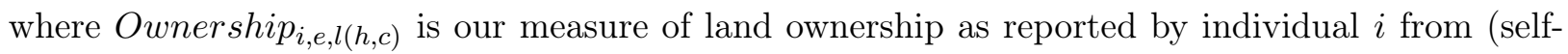
reported) ethnic group $e$ living in location $l$ situated in historical ethnic homeland $h$ and country $c$. Distance $_{l}$ is the logged distance from the location of the respondent to the closest historical ethnic border. $X_{i}$ is the vector of basic individual controls (i.e., gender, age and its square) whereas the vector $G_{l}$ includes the basic set of geographic and climatic variables exploited in previous regressions (computed for a $25 \mathrm{~km}$ buffer around location $l$ ). $\Phi_{e}, \Theta_{h}, \Omega_{w}$, and $\Pi_{c}$ refer to a full set of (self-reported) ethnicity, ethnic homeland, wave, and country fixed effects, respectively. Finally, $\epsilon_{h}$ is an error term, which is allowed to be heteroskedastic and correlated at the ethnic homeland level.

The DHS Program distributes surveys separately for women and men; being the dataset larger and more comprehensive for the former. While we focus our analysis on women, we also show in the appendix that results are very similar regardless of the gender of the individual interviewed. Nonetheless, when in cohabitation, women are also asked about ownership of the land for their partners or other family members. Therefore, our measure of land ownership reflects ownership of the land of any household member.

Although our preferred econometric analysis (as reflected in (2)) compares individuals within the same (self-reported) ethnic group, DHS data does not report ethnic affiliation for approximately 30 percent of our sample. Thus, in Table 10 we show the results of IV estimations for the sample of individuals for whom landownership data is available, as well as for those for whom self-reported ethnic affiliation is reported. Further, we also restrict our analysis for different samples: individuals 
living in rural areas, migrants living in rural areas, and rural migrants living in rural areas (i.e, ruralrural migrants). Focused on females, in column 5 to 6 we present the main results of our preferred econometric specification for all, rural resident, rural migrants, and rural-rural migrants. We find that proximity to the historical ethnic border strongly reduces the likelihood of land ownership. The estimated effect in column 5 is quite large and implies that moving an individual in the lowest decile of distance (i.e., $2 \mathrm{~km}$ from the border) to the highest decile of distance (i.e., $58 \mathrm{~km}$ from the border) will increase the probability of land ownership by 24 percentage points. We find quantitatively similar results for the sample of females living in rural areas (column 6). Further, we document a larger effect for migrant living in rural areas (column 7), particularly those identified as rural-rural migrants. ${ }^{48}$

Table 10: Historical Ethnic Borders and Female Land Ownership in Africa (IV)

\begin{tabular}{|c|c|c|c|c|c|c|c|c|}
\hline & \multicolumn{8}{|c|}{ Female Land Ownership } \\
\hline & \multicolumn{4}{|c|}{ Full Sample } & \multicolumn{4}{|c|}{ Self-Reported Ethnicity } \\
\hline & All & Rural & $\begin{array}{c}\text { Rural } \\
\text { Migrant }\end{array}$ & $\begin{array}{c}\text { Rural- } \\
\text { Rural } \\
\text { Migrant }\end{array}$ & All & Rural & $\begin{array}{c}\text { Rural } \\
\text { Migrant }\end{array}$ & $\begin{array}{c}\text { Rural- } \\
\text { Rural } \\
\text { Migrant }\end{array}$ \\
\hline & (1) & $(2)$ & $(3)$ & $(4)$ & $(5)$ & (6) & $(7)$ & $(8)$ \\
\hline Log[Distance to Ethnic Border] & $\begin{array}{l}0.019 * * * \\
(0.007)\end{array}$ & $\begin{array}{l}0.028^{* * *} \\
(0.008)\end{array}$ & $\begin{array}{l}0.036^{*} \\
(0.021)\end{array}$ & $\begin{array}{l}0.050^{*} \\
(0.027)\end{array}$ & $\begin{array}{l}0.035^{* * *} \\
(0.010)\end{array}$ & $\begin{array}{l}0.045^{* * *} \\
(0.015)\end{array}$ & $\begin{array}{l}0.073^{*} \\
(0.042)\end{array}$ & $\begin{array}{l}0.100 * * \\
(0.043)\end{array}$ \\
\hline Country FE & Yes & Yes & Yes & Yes & Yes & Yes & Yes & Yes \\
\hline Wave FE & Yes & Yes & Yes & Yes & Yes & Yes & Yes & Yes \\
\hline Ethnic Homeland FE & Yes & Yes & Yes & Yes & Yes & Yes & Yes & Yes \\
\hline Geographical Controls & Yes & Yes & Yes & Yes & Yes & Yes & Yes & Yes \\
\hline Individual Controls & Yes & Yes & Yes & Yes & Yes & Yes & Yes & Yes \\
\hline Self-Reported Ethnicity FE & No & No & No & No & Yes & Yes & Yes & Yes \\
\hline Mean Prevalence & 0.37 & 0.44 & 0.54 & 0.54 & 0.36 & 0.43 & 0.55 & 0.56 \\
\hline First-stage F-statistic & 113.92 & 101.85 & 58.34 & 45.50 & 50.41 & 44.11 & 19.07 & 22.06 \\
\hline Adjusted- $R^{2}$ & 0.08 & 0.08 & 0.03 & 0.01 & 0.06 & 0.05 & -0.01 & -0.04 \\
\hline Observations & 629283 & 443611 & 96343 & 60772 & 427170 & 297198 & 61085 & 42659 \\
\hline
\end{tabular}

Notes: Heteroskedasticity robust standard error estimates clustered at the ethnic homeland-level are reported in parentheses; $* * *$ denotes statistical significance at the $1 \%$ level, $* *$ at the $5 \%$ level, and * at the $10 \%$ level, all for two-sided hypothesis tests. Main Controls refer to the sets of Geographic and Climatic controls described in Table 1 (computed for a $25 \mathrm{~km}$ buffer around respondents' location).

\subsection{Hard vs. Soft Borders}

Previous literature on international interactions has studied the role of different types of borders as barriers or catalysts of conflict and disputes. Particular attention has been paid to elevation and rivers, as well as whether borders are "artificial" (Alesina et al., 2011). Indeed, ad-hoc, or somehow arbitrary, boundaries not following topographic features make borderlines more fuzzy and thus potentially serve as a perfect excuse for conflict. Indeed, fuzzy historical ethnic borders may be conducive to overlap-

\footnotetext{
${ }^{48}$ In Table C.27 we also include males in our sample and find very similar results.
} 
ping claims on resources, inter-ethnic contact and encroachment, as well as weak ethnic and personal property rights.

In Table 11 we explore the potential effects from the congruence of our measure of historical ethnic borders and various geographical, ecological, and political borders. In particular, we are interested in understanding whether the level of fuzziness of historical ethnic borders, due to either geographic (e.g., mountains) or de jure (e.g., administrative borders) characteristics, mitigate or exacerbate conflict. To do so we compute measures of the prevalence of these characteristics around historical ethnic borders. Specifically, in order to differentiate very local geographical characteristics at the border from the geographical characteristics of the cell in which the border is located, for geographic characteristics (e.g., elevation or ruggedness of terrain) we compute their mean value within a $2.5 \mathrm{~km}$-buffer around the border. Additionally, to try to capture the similarity and overlap between historical ethnic borders and linear features (e.g., rivers or administrative borders), we compute the share of the ethnic border that falls within $10 \mathrm{kms}$ of the linear feature. Although potentially mismeasured, this should proxy for the similarity in the shape of the ethnic border with these linear features. ${ }^{49}$

In all columns of Table 11 the association between conflict and historical ethnic borders remains positive and significant. In columns 2 and 3 we explore the effect of elevation and terrain ruggedness around the border. Our results suggest that both elevation and ruggedness are strongly associated to the prevalence of contemporary conflict, albeit in different ways. On the one hand, mean elevation at the cell level is positively associated with conflict, but elevation at the border does not exert a significant heterogeneous impact. On the other hand, only terrain ruggedness around historical ethnic borders seems to predict conflict. These results are in line with the strategic and military importance of elevated and rugged areas. Moreover, given the difficulty of controlling rugged areas, rugged borders may be subject to more conflict.

As we show in column 4, the presence of rivers in a cell increases the likelihood of conflict, which is consistent with the strategic importance of navigable rivers for warring factions. Moreover, rivers may harbor densely populated areas which tend to strongly correlate with conflict. Additionally, we find that when rivers overlap with historical ethnic borders the statistical association turns negative (albeit statistically insignificant under the standard levels of confidence). This may reflect mismeasurement of the overlap, or the fact that even if no measurement error were present, rivers at borders may have dual effects. On the one hand, rivers are economically and strategically valuable, which may increase conflict at rivers. On the other, rivers may make borders less fuzzy, as they improve demarcation, which should lead to less conflict. ${ }^{50}$ Similarly, in column 5 we show that the coincidence of ethnic borders with coastlines (either from oceans, seas or lakes) negatively predicts conflict. In column 6 we find a similar pattern when we look at ecological borders (albeit the negative correlation is not

\footnotetext{
${ }^{49}$ Given the nature of the historical ethnic borders and the Murdock map, it may be the case that although a border overlaps a linear feature exactly, it is misrepresented in the map. Our strategy tries to recover this potential overlap.

${ }^{50}$ It is important to note, that our strategy mitigates the potential role of rivers to cause conflict due to running from one ethnic homeland into another generating an upstream/downstream relations between ethnic groups (Toset et al., 2000). In particular, it has been argued that an upstream/downstream relationship has a higher conflict potential. For example, if the upstream actor restricts the supply of water, the downstream actor has strong incentives to initiate conflict. On the other hand, the downstream actor can restrict navigation for its upstream counterpart, increasing the conflict incentives for the later.
} 
Table 11: Historical Ethnic Borders and Conflict (IV)

Hard vs. Soft Borders

\begin{tabular}{|c|c|c|c|c|c|c|c|c|}
\hline & \multicolumn{8}{|c|}{ Prevalence of Conflict } \\
\hline & Main & Elevation & RIX & River & Coast & $\begin{array}{l}\text { Ecological } \\
\text { Border }\end{array}$ & $\begin{array}{l}\text { Adm1 } \\
\text { Border }\end{array}$ & $\begin{array}{l}\text { National } \\
\text { Border }\end{array}$ \\
\hline & $(1)$ & $(2)$ & $(3)$ & $(4)$ & $(5)$ & (6) & $(7)$ & (8) \\
\hline Presence of Ethnic Border & $\begin{array}{l}0.273^{* * *} \\
(0.066)\end{array}$ & $\begin{array}{l}0.277^{* * *} \\
(0.067)\end{array}$ & $\begin{array}{l}0.234^{* * *} \\
(0.066)\end{array}$ & $\begin{array}{l}0.280^{* * *} \\
(0.068)\end{array}$ & $\begin{array}{l}0.510^{* * *} \\
(0.170)\end{array}$ & $\begin{array}{l}0.377^{* * *} \\
(0.144)\end{array}$ & $\begin{array}{l}0.432^{* * *} \\
(0.117)\end{array}$ & $\begin{array}{l}0.415^{* * *} \\
(0.130)\end{array}$ \\
\hline Characteristic at Border & & $\begin{array}{l}-0.017 \\
(0.021)\end{array}$ & $\begin{array}{l}0.045^{* * *} \\
(0.011)\end{array}$ & $\begin{array}{l}-0.002 \\
(0.024)\end{array}$ & $\begin{array}{l}-0.074^{*} \\
(0.038)\end{array}$ & $\begin{array}{l}-0.055 \\
(0.039)\end{array}$ & $\begin{array}{l}-0.070^{* *} \\
(0.032)\end{array}$ & $\begin{array}{c}-0.057^{*} \\
(0.033)\end{array}$ \\
\hline Characteristic in Cell & & $\begin{array}{l}0.039 * * * \\
(0.011)\end{array}$ & $\begin{array}{l}-0.006 \\
(0.007)\end{array}$ & $\begin{array}{l}0.062^{*} \\
(0.033)\end{array}$ & $\begin{array}{l}0.025 \\
(0.048)\end{array}$ & $\begin{array}{l}0.067^{* * *} \\
(0.024)\end{array}$ & $\begin{array}{l}-0.019 \\
(0.013)\end{array}$ & $\begin{array}{l}-0.052^{* * *} \\
(0.017)\end{array}$ \\
\hline Country FE & Yes & Yes & Yes & Yes & Yes & Yes & Yes & Yes \\
\hline Ethnic FE & Yes & Yes & Yes & Yes & Yes & Yes & Yes & Yes \\
\hline Main Controls & Yes & Yes & Yes & Yes & Yes & Yes & Yes & Yes \\
\hline First-stage F-statistic & 34.14 & 17.32 & 16.89 & 23.01 & 14.02 & 12.93 & 21.58 & 17.83 \\
\hline Adjusted- $R^{2}$ & 0.30 & 0.30 & 0.31 & 0.30 & 0.25 & 0.29 & 0.29 & 0.29 \\
\hline Observations & 14078 & 14078 & 14078 & 14078 & 14078 & 14078 & 14078 & 14078 \\
\hline
\end{tabular}

Notes: Heteroskedasticity robust standard error estimates clustered at the country-level are reported in parentheses; $* * *$ denotes statistical significance at the $1 \%$ level, ${ }^{* *}$ at the $5 \%$ level, and $*$ at the $10 \%$ level, all for two-sided hypothesis tests. Main Controls refer to the sets of Geographic and Climatic controls described in Table 1. RIX is a measure of terrain ruggedness calculated following the methodology of Riley et al. (1999).

statistically significant under the standard levels of confidence). In sum, the statistical pattern we find in the data is consistent with the idea that borders determined by geography such as water bodies, may ease border demarcation, thus decreasing border fuzzyness and conflict.

We next explore how the coincidence of historical ethnic borders and contemporary de jure borders affects conflict. In particular, we expect historical borders that closely follow contemporary de jure borders to be less conducive to conflict as the authority and territorial issues underlying the demarcation of ethnic homelands may have been resolved in these locations. In line with this hypothesis, we find that historical ethnic borders that coincide with those of subnational administrative units correlate less with modern conflict (Column 7). This result echoes the findings of Bazzi and Gudgeon (2021), who find that "[r]edrawing district borders along group lines reduces conflict". Similarly, at historical ethnic borders that overlap with national borders conflict is also less prevalent (Column 8). ${ }^{51}$

\footnotetext{
${ }^{51}$ Notice that our measure prevents the analysis of capturing the effect of national borders on conflict due to ethnic partitioning. While national borders may be present in the cell and cut ethnic borders, causing ethnic partition, our measure only focuses on overlaps between ethnic and national borders (i.e., captures if they run parallel to each other). See Table C.42 for the basic interaction of ethnic border presence with these other borders at the cell-level. Moreover, we explore whether split ethnicities or ethnicities whose neighbors are split drive our main results (Table C.16). Reassuringly, the results are similar for split and non-split ethnicities, as well as for ethnicities that are not split and which do not have split neighbors.
} 


\section{Concluding Remarks}

This research explored the contribution of historical ethnic borders to contemporary conflict in Africa. Our analyses suggest a statistically and economically significant positive association between the location of historical ethnic borders and contemporary non-civil conflict. This results is robust to a large set of robustness checks, which suggests the estimated coefficient can be given a causal interpretation. We explore this potential causal role and present suggestive evidence that conflict is more prevalent, intense, and starts more often at historical ethnic borders. Borders role seems to be especially important for non-civil, local and ethnic conflicts, as well as territorial and authority disputes. Moreover, we present evidence that the role of borders is amplified at borders that are agriculturally suitable, have experienced a recent increase in population, and in which culturally similar ethnicities interact. Additionally, we provide evidence that landownership close to the border is less prevalent. Finally, we provide evidence suggesting that formalizing historical ethnic borders, changing them from de facto borders to actual de jure borders, e.g., via administrative borders, may decrease conflict.

\section{References}

Acemoglu, D., Fergusson, L. and Johnson, S. (2017). Population and civil war, NBER Working Paper No. 23322.

Acemoglu, D., Johnson, S. and Robinson, J. (2005). Institutions as a fundamental cause of long-run growth, Handbook of economic growth 1: 385-472.

Aker, J. C., Klein, M. W., O'Connell, S. A. and Yang, M. (2014). Borders, ethnicity and trade, Journal of Development Economics 107(C): 1-16.

Alesina, A., Devleeschauwer, A., Easterly, W., Kurlat, S. and Wacziarg, R. T. (2003). Fractionalization, Journal of Economic Growth 8(2): 155-194.

Alesina, A., Easterly, W. and Matuszeski, J. (2011). Artificial states, Journal of the European Economic Association 9(2): 246-277.

Alesina, A. and La Ferrara, E. (2005). Ethnic diversity economic performance, Journal of economic literature 43(3): 762-800.

Alsan, M. (2015). The effect of the tsetse fly on african development, American Economic Review 105(1): 382-410.

André, C. and Platteau, J.-P. (1998). Land relations under unbearable stress: Rwanda caught in the malthusian trap, Journal of Economic Behavior \& Organization 34(1): 1 - 47.

Austin, G. (2008). Resources, techniques, and strategies south of the sahara: revising the factor endowments perspective on african economic development, 1500-20001, The Economic History Review 61(3): 587-624.

Bates, R. H. (2008). When Things Fell Apart: State Failure in Late-Century Africa, Cambridge University Press.

Bazzi, S. and Blattman, C. (2014). Economic shocks and conflict: Evidence from commodity prices, American Economic Journal: Macroeconomics 6(4): 1-38. 
Bazzi, S. and Gudgeon, M. (2021). The political boundaries of ethnic divisions, American Economic Journal: Applied Economics 13(1): 235-66.

Berman, N. and Couttenier, M. (2015). External shocks, internal shots: the geography of civil conflicts, Review of Economics and Statistics 97(4): 758-776.

Berman, N., Couttenier, M., Rohner, D. and Thoenig, M. (2017). This mine is mine! how minerals fuel conflicts in africa, American Economic Review 107(6): 1564-1610.

Berman, N., Couttenier, M. and Soubeyran, R. (2019). Fertile Ground for Conflict, Journal of the European Economic Association . jvz068.

Besley, T. and Reynal-Querol, M. (2014). The legacy of historical conflict: Evidence from africa, American Political Science Review 108(2): 319-336.

Black, D. A., Berger, M. C. and Scott, F. A. (2000). Bounding parameter estimates with nonclassical measurement error, Journal of the American Statistical Association 95(451): 739-748.

Blattman, C. and Miguel, E. (2010). Civil war, Journal of Economic literature 48(1): 3-57.

Boone, C. (2017). Sons of the soil conflict in africa: Institutional determinants of ethnic conflict over land, World Development 96: 276 - 293.

Boone, C. and Nyeme, L. (2015). Land institutions and political ethnicity in africa: Evidence from tanzania, Comparative Politics 48(1): 67-86.

Brecke, P. (1999). Violent conflicts 1400 a.d. to the present in different regions of the world, Technical report, Paper presented at the 1999 meeting of the Peace Science Society.

Brochmann, M. and Gleditsch, N. P. (2012). Shared rivers and conflict - a reconsideration, Political Geography 31(8): $519-527$.

Bubb, R. (2013). The evolution of property rights: state law or informal norms?, The Journal of Law and Economics 56(3): 555-594.

Caselli, F., Morelli, M. and Rohner, D. (2015). The geography of interstate resource wars, The Quarterly Journal of Economics 130(1): 267-315.

Colella, F., Lalive, R., Sakalli, S. and Thoenig, M. (2018). Inference with arbitrary clustering, Technical report, University of Lausanne.

Depetris-Chauvin, E. (2014). State history and contemporary conflict: Evidence from sub-saharan africa, Technical report, Brown University.

Depetris-Chauvin, E., Durante, R. and Campante, F. (2020). Building nations through shared experiences: Evidence from african football, American Economic Review 110(5): 1572-1602.

Depetris-Chauvin, E. and Özak, Ö. (2016). Population diversity, division of labor and comparative development, Working Paper, Southern Methodist University, Department of Economics .

Depetris-Chauvin, E. and Özak, Ö. (2018). The origins of the division of labor in pre-modern times, Technical report, SSRN.

Depetris-Chauvin, E. and Weil, D. N. (2018). Malaria and early african development: Evidence from the sickle cell trait, The Economic Journal 128(610): 1207-1234. 
Desmet, K., Ortuño-Ortín, I. and Wacziarg, R. (2017). Culture, ethnicity, and diversity, American Economic Review 107(9): 2479-2513.

Diamond, J. M. (1997). Guns, germs, and steel: the fates of human societies, 1st ed edn, W.W. Norton \& Co., New York.

Dobler, G. (2008). Boundary drawing and the notion of territoriality in pre-colonial and early colonial ovamboland, Journal of Namibian Studies: History Politics Culture 3: 7-30.

Easterly, W. and Levine, R. (1997). Africa's growth tragedy: policies and ethnic divisions, The Quarterly Journal of Economics pp. 1203-1250.

Englebert, P., Tarango, S. and Carter, M. (2002). Dismemberment and suffocation: A contribution to the debate on african boundaries, Comparative Political Studies 35(10): 1093-1118.

Fanso, V. G. (1984). African traditional and european colonial boundaries: Concepts and functions in inter-group relations with special reference to south western cameroon, Journal of the Historical Society of Nigeria 12(3/4): 23-43.

Faris, S. (2009). Forecast: The Surprising and Immediate Consequences of Climate Change, New York: Holt and Company.

Fearon, J. D. (2003). Ethnic and cultural diversity by country, Journal of economic growth 8(2): 195222 .

Fearon, J. D. and Laitin, D. D. (2011). Sons of the soil, migrants, and civil war, World Development 39(2): 199 - 211. Ethnicity and Ethnic Strife.

Fenske, J. (2014). Ecology, trade, and states in pre-colonial africa, Journal of the European Economic Association 12(3): 612-640.

Fjelde, H. and Østby, G. (2014). Socioeconomic inequality and communal conflict: A disaggregated analysis of sub-saharan africa, 1990-2008, International Interactions 40(5): 737-762.

Galor, O. and Özak, Ö. (2015). Land productivity and economic development: Caloric suitability vs. agricultural suitability, SMU Working Paper Series .

Galor, O. and Özak, Ö. (2016). The agricultural origins of time preference, American Economic Review 106(10).

GLOBE Task Team and others (ed.) (1999). The Global Land One-kilometer Base Elevation (GLOBE) Digital Elevation Model, Version 1.0., National Oceanic and Atmospheric Administration, National Geophysical Data Center, 325 Broadway, Boulder, Colorado 80303, U.S.A.

Guiso, L., Sapienza, P. and Zingales, L. (2009). Cultural biases in economic exchange?, Quarterly Journal of Economics 124(3): 1095-1131.

Harari, M. and Ferrara, E. L. (2018). Conflict, climate, and cells: a disaggregated analysis, Review of Economics and Statistics 100(4): 594-608.

Herbst, J. (1990). War and the state in africa, International Security 14(4): 117-139.

Herbst, J. (2000). States and Power in Africa: Comparative Lessons in Authority and Control, stu student edition edn, Princeton University Press. 
Horowitz, D., L, H. and Horowitz, P. (1985). Ethnic Groups in Conflict, Political science. Sociology: Area Studies, University of California Press.

Jayne, T., Mather, D. and Mghenyi, E. (2010). Principal challenges confronting smallholder agriculture in sub-saharan africa, World Development 38(10): 1384 - 1398. The Future of Small Farms Including Special Section: Impact Assessment of Policy-Oriented International Agricultural Research (pp. 1453-1526).

Klein Goldewijk, K., Beusen, A., Van Drecht, G. and De Vos, M. (2011). The hyde 3.1 spatially explicit database of human-induced global land-use change over the past 12,000 years, Global Ecology and Biogeography 20(1): 73-86.

Lewis, M. P., Simons, G. F. and Fennig, C. D. (2009). Ethnologue: Languages of the world, Vol. 16, SIL international Dallas, TX.

Livi Bacci, M. (1997). A concise history of world population / Massimo Livi-Bacci ; translated by Carl Ipsen, 2nd ed. edn, Blackwell Cambridge, MA.

McCauley, J. F. and Posner, D. N. (2015). African borders as sources of natural experiments promise and pitfalls, Political Science Research and Methods 3(2): 409-418.

McGuirk, E. and Burke, M. (2020). The economic origins of conflict in africa, Journal of Political Economy Forthcoming.

Michalopoulos, S. (2012). The origins of ethnolinguistic diversity, The American Economic Review 102(4): 1508.

Michalopoulos, S. and Papaioannou, E. (2013a). National Institutions and Subnational Development in Africa *, The Quarterly Journal of Economics 129(1): 151-213.

Michalopoulos, S. and Papaioannou, E. (2013b). Pre-colonial ethnic institutions and contemporary african development, Econometrica 81(1): 113-152.

Michalopoulos, S. and Papaioannou, E. (2016). The long-run effects of the scramble for africa, American Economic Review 106(7): 1802-48.

Miguel, E. (2004). Tribe or nation? nation building and public goods in kenya versus tanzania, World Politics 56(3): 327-362.

Miguel, E., Satyanath, S. and Sergenti, E. (2004). Economic shocks and civil conflict: An instrumental variables approach, Journal of Political Economy 112(4): 725-753.

Moore, J. L., Manne, L., Brooks, T., Burgess, N. D., Davies, R., Rahbek, C., Williams, P. and Balmford, A. (2002). The distribution of cultural and biological diversity in africa, Proceedings of the Royal Society of London B: Biological Sciences 269(1501): 1645-1653.

Moscona, J., Nunn, N. and Robinson, J. A. (2020). Segmentary lineage organization and conflict in sub-saharan africa, Econometrica 88(5): 1999-2036.

Müller, H.-P. (1999). Atlas vorkolonialer Gesellschaften: kulturelles Erbe und Sozialstrukturen der Staaten Afrikas, Asiens und Melanesiens : ein ethnologisches Kartenwerk für 95 Länder, mit digitalem Buch, Datenbanken und Dokumentationen aud CD-ROM, Reimer, Berlin.

Murdock, G. P. (1959). Africa: its peoples and their culture history, McGraw-Hill, New York. 
Murdock, G. P. (1967). Ethnographic atlas: a summary, Ethnology pp. 109-236.

Nettle, D. (1998). Explaining global patterns of language diversity, Journal of anthropological archaeology 17(4): 354-374.

Nunn, N. (2008). The long-term effects of africa's slave trades, The Quarterly Journal of Economics 123(1): 139-176.

Nunn, N. and Wantchekon, L. (2011). The slave trade and the origins of mistrust in africa, American Economic Review 101(7): 3221-52.

Özak, Ö. (2010). The voyage of homo-economicus: Some economic measures of distance.

Özak, Ö. (2018). Distance to the pre-industrial technological frontier and economic development, Journal of Economic Growth 23(2): 175-221.

Platteau, J.-P. (2002). The gradual erosion of the social security function of customary land tenure arrangements in lineage-based societies, number 2002/26, WIDER Discussion Papers//World Institute for Development Economics (UNU-WIDER).

Raleigh, C., Linke, A., Hegre, H. and Karlsen, J. (2010). Introducing ACLED: an Armed Conflict Location and Event Dataset: special data feature, Journal of peace research 47(5): 651-660.

Ramankutty, N., Foley, J. A., Norman, J. and McSweeney, K. (2002). The global distribution of cultivable lands: current patterns and sensitivity to possible climate change, Global Ecology and biogeography 11(5): 377-392.

Ray, D. and Esteban, J. (2017). Conflict and development, Annual Review of Economics 9(1): 263-293.

Riley, S., DeGloria, S. and Elliot, R. (1999). A terrain ruggedness index that quantifies topographic heterogeneity, Intermountain Journal of Sciences 5(1-4): 23-27.

Spolaore, E. (2009). National borders, conflict and peace, The Oxford Handbook of the Economics of Peace and Conflict, Oxford University Press, chapter 30.

Spolaore, E. and Wacziarg, R. (2009). War and relatedness, Technical report, National Bureau of Economic Research.

Spolaore, E. and Wacziarg, R. (2016). War and relatedness, The Review of Economics and Statistics 98(5): 925-939.

Starr, H. (1978). "Opportunity" and "willingness' as ordering concepts in the study of war, International Interactions 4(4): 363-387.

Starr, H. (2002). Opportunity, willingness and geographic information systems (gis): reconceptualizing borders in international relations, Political Geography 21(2): 243 - 261.

Starr, H. and Most, B. A. (1976). The substance and study of borders in international relations research, International Studies Quarterly 20(4): 581-620.

Sundberg, R. and Melander, E. (2013). Introducing the UCDP georeferenced event dataset, Journal of Peace Research 50(4): 523-532.

Toset, H. P. W., Gleditsch, N. P. and Hegre, H. (2000). Shared rivers and interstate conflict, Political Geography 19(8): $971-996$. 
Vasquez, J. A. (1993). The War Puzzle, Cambridge Studies in International Relations, Cambridge University Press.

Weidmann, N. B., Rød, J. K. and Cederman, L.-E. (2010). Representing ethnic groups in space: A new dataset, Journal of Peace Research 47(4): 491-499. 


\title{
Online Appendix (Not for Publication)
}

\author{
Available for download here
}




\section{Appendix (For Online Publication)}

\section{A Additional Figures}

\section{A.1 Historical Ethnic and Voronoi Borders}

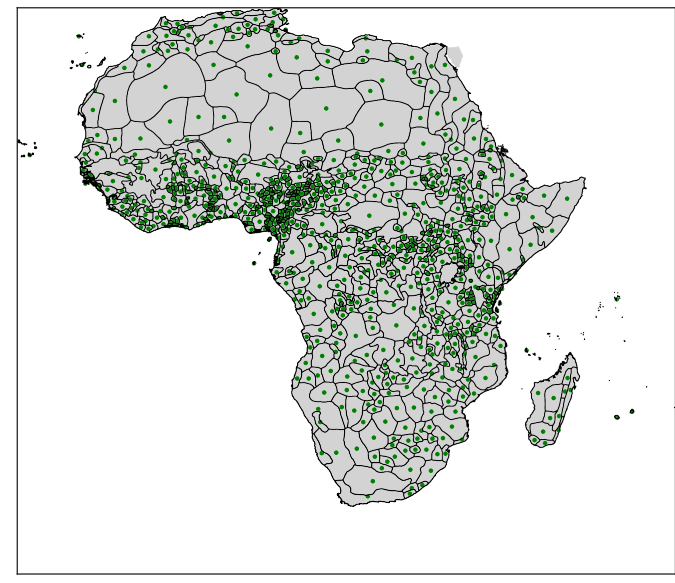

(a) Historical Borders \& Centroids of Ethnic Homelands

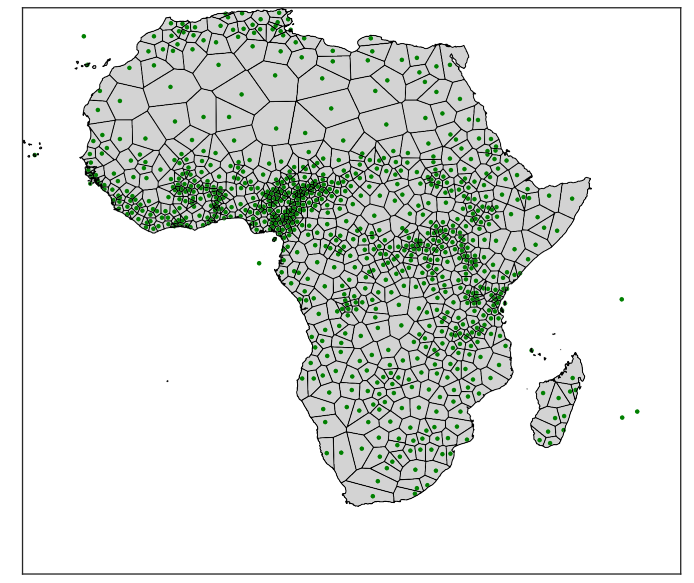

(b) Potential Borders \& Centroids of Ethnic Homelands

Figure A.1: Historical Ethnic Borders, Centroids and Potential (Voronoi) Borders in Africa

\section{A.2 Spatial Distribution of Conflict}




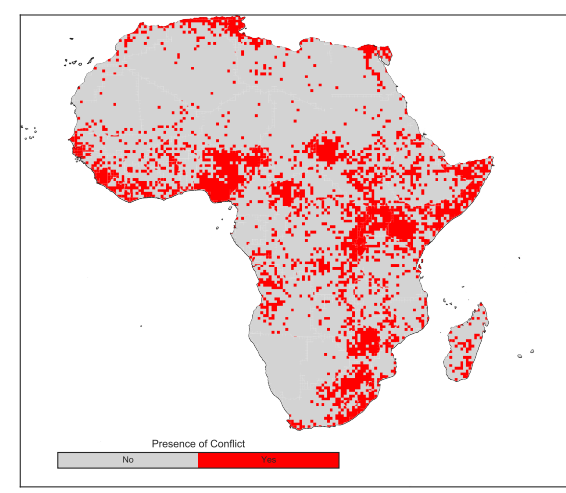

(a) Prevalence

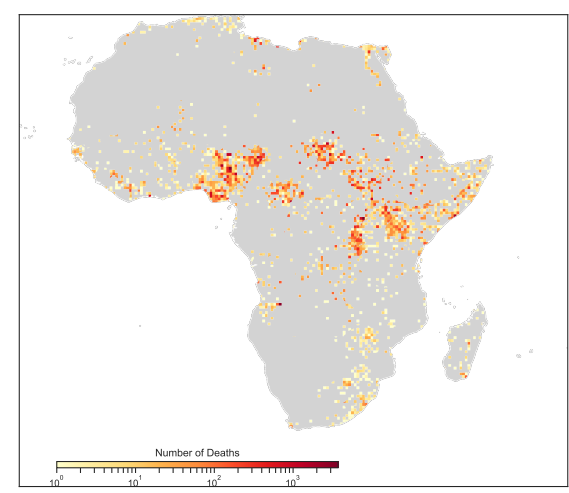

(c) Number of Deaths

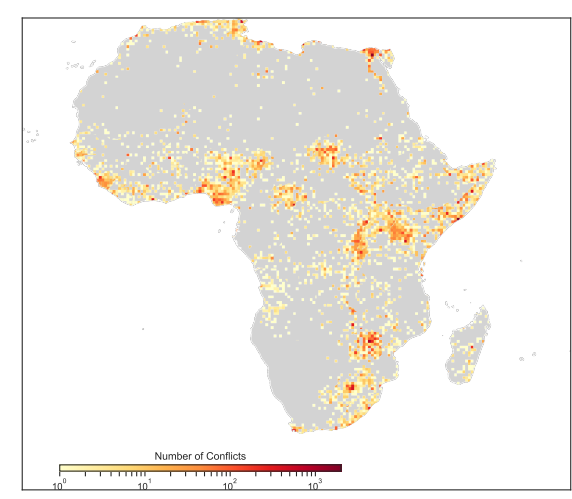

(b) Number of Events

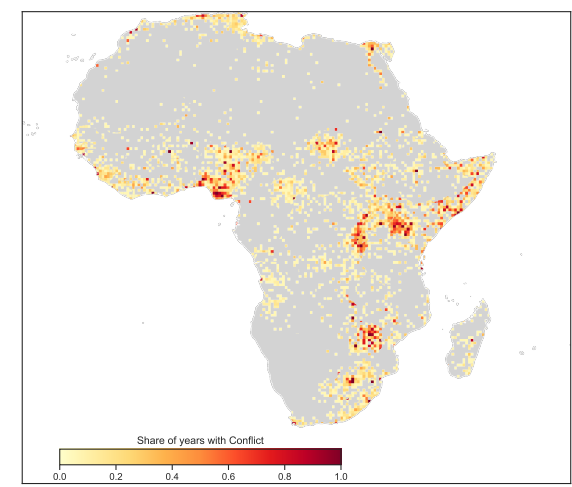

(d) Share of Years with Conflict

Figure A.2: Conflict in Africa (ACLED) 


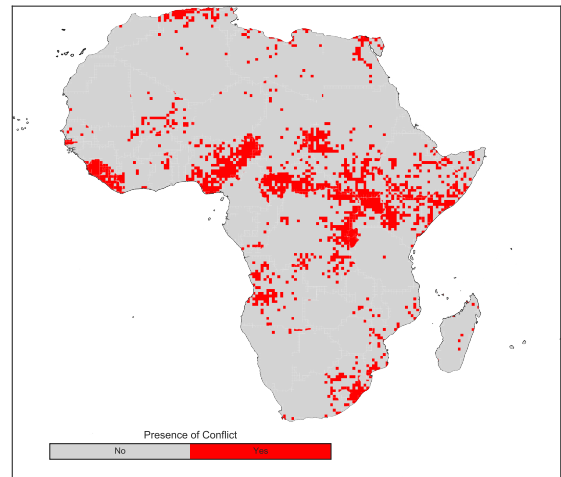

(a) Prevalence

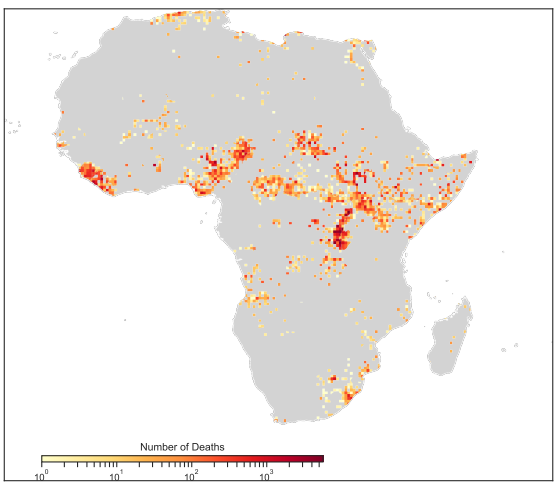

(c) Number of Deaths

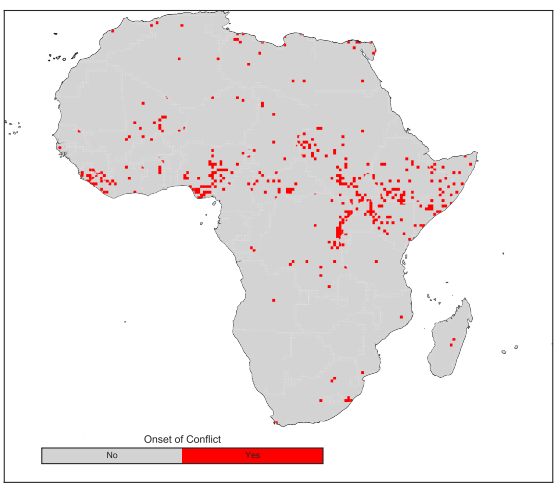

(e) Prevalence of Conflict Onsets

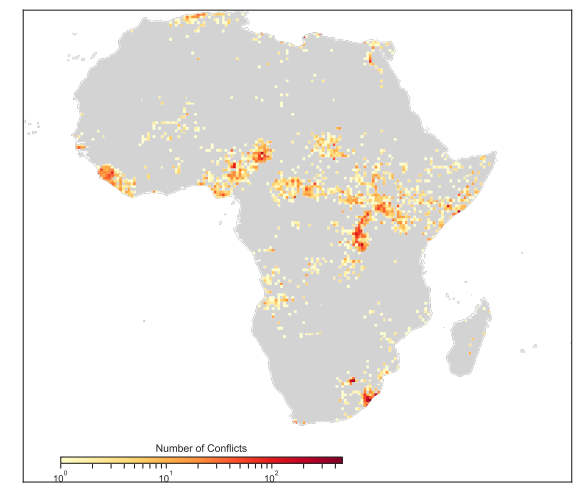

(b) Number of Events

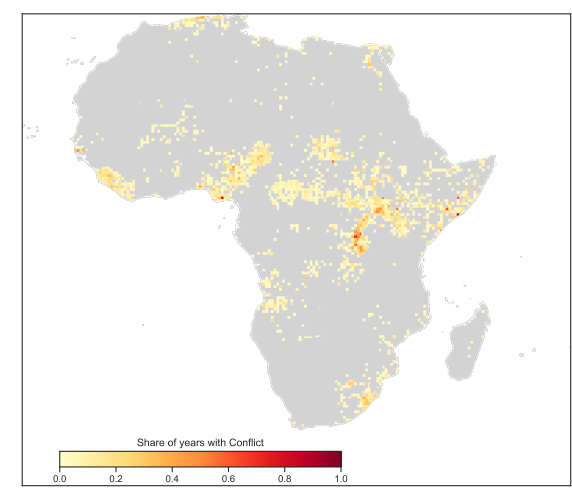

(d) Share of Years with Conflict

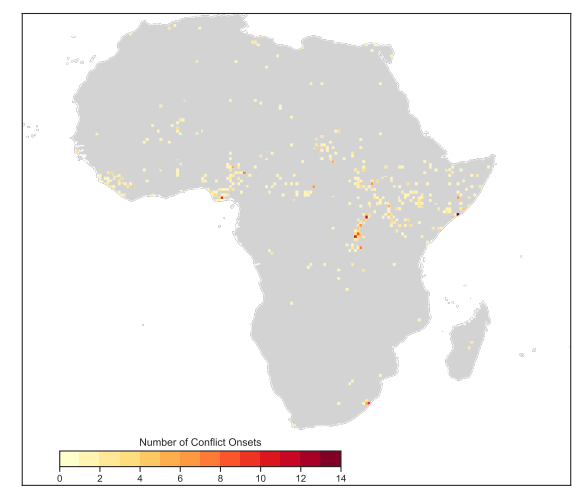

(f) Number of Conflict Onsets

Figure A.3: Conflict in Africa (UCDP-GED) 


\section{A.3 Conflict and Proximity to Historical Ethnic Borders}

Figure A.4 presents some descriptive statistics and associations between historical ethnic borders and contemporary conflict. Specifically, Figures (a1) and (a2) depict for each cell that experienced conflict according to ACLED and PRIO, its distance to the closest historical ethnic border, where darker tones denote smaller distances. Clearly, most cells in Africa that experienced conflict are a short distance from a historical ethnic border. Figures (b1) and (b2) show additional patterns consistent of the potential link between historical borders and conflict. In particular, these figures show the distribution of distances between cell's centroids and some of the main sources of conflict identified in the literature. It is apparent that conflict occurs closer to historical ethnic borders than to any of these other sources. Figures (c1) and (c2) show the distribution of distances to historical ethnic borders for cells that experienced conflict and those which did not. The difference in these distributions is quite noticeable and suggests that locations close to a historical ethnic border are more prone to conflict. This is further supported by Figures (d1) and (d2), which depict the probabilities of conflict across cells with and without historical ethnic borders. Clearly, cells with historical ethnic borders have a much higher probability of contemporary conflict. 


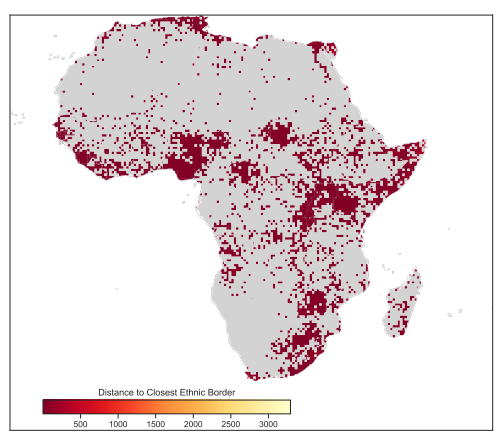

(a1) ACLED

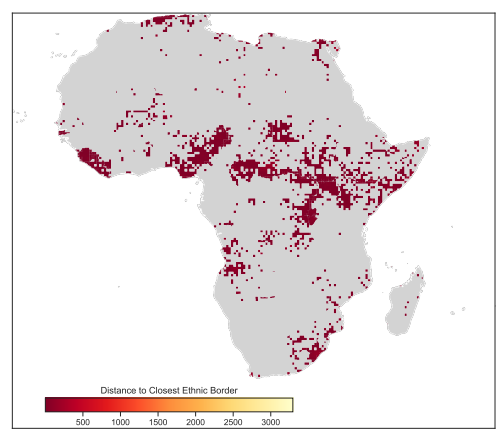

(a2) PRIO

(a) Distance to Closest Ethnic Border

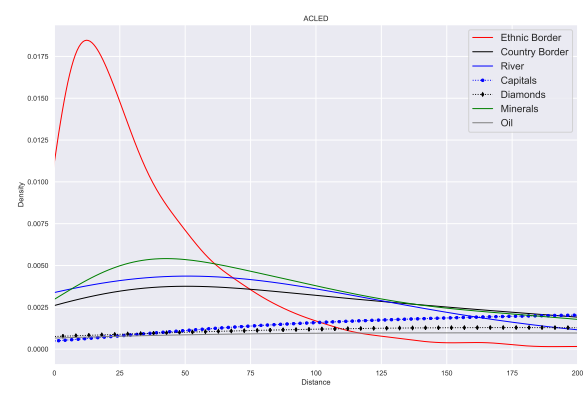

(b1) ACLED

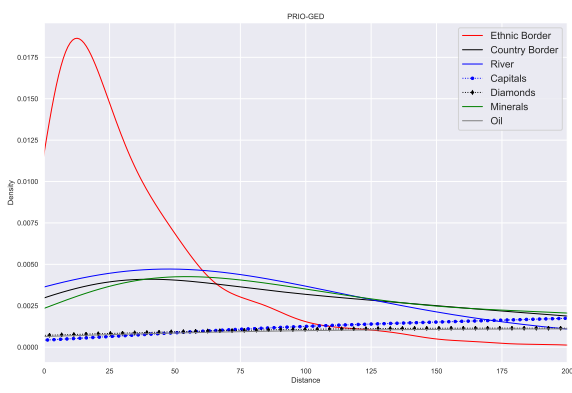

(b2) PRIO

(b) Density of Distances to Sources of Conflict

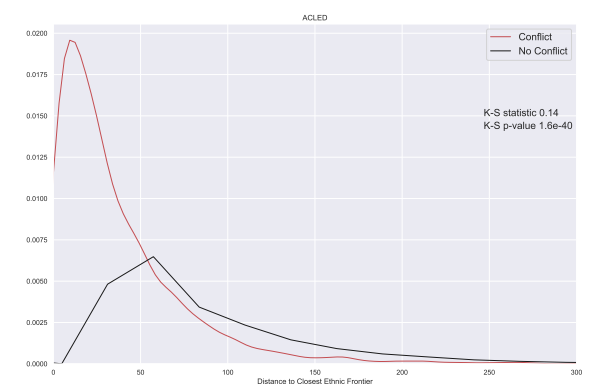

(c1) ACLED

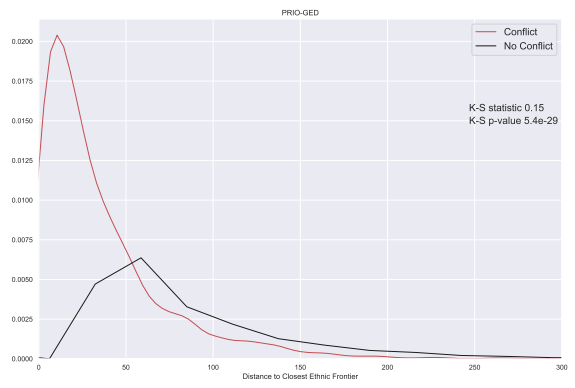

(c2) PRIO

(c) Distribution of Distances to Closest Ethnic Border

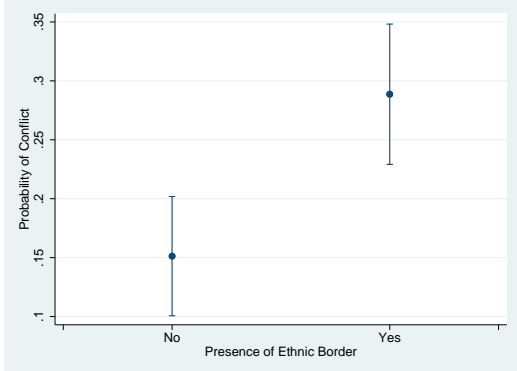

(d1) ACLED

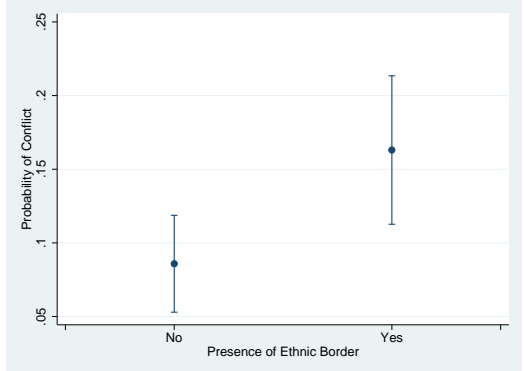

(d2) PRIO

(d) Conflict Probability Cells with and without Historical Ethnic Borders

Figure A.4: Ethnic Borders and Conflict in Africa 


\section{A.4 Other Sources of Conflict}

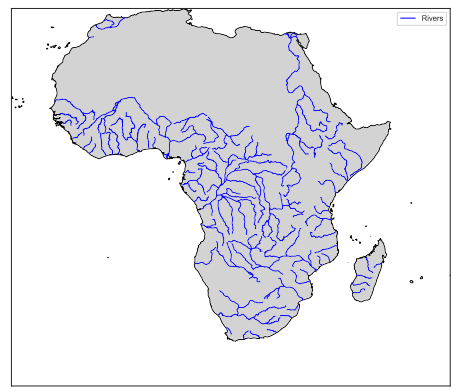

(a) Rivers

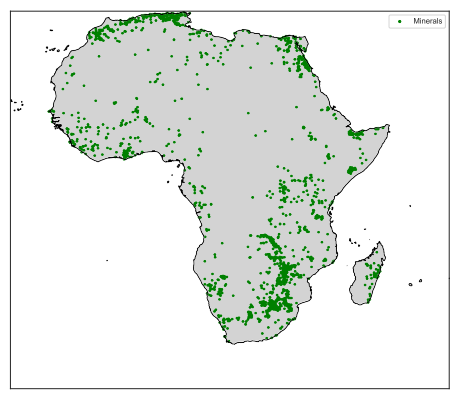

(d) Minerals

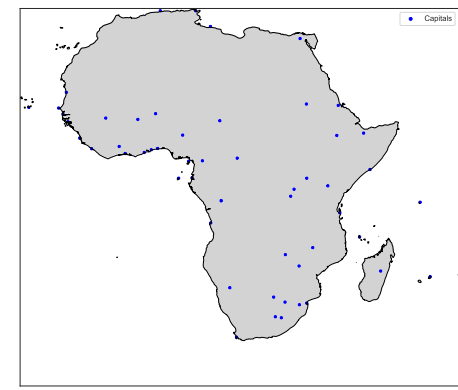

(b) Capitals

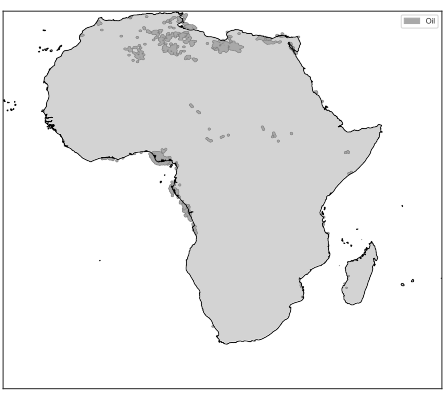

(e) Oil

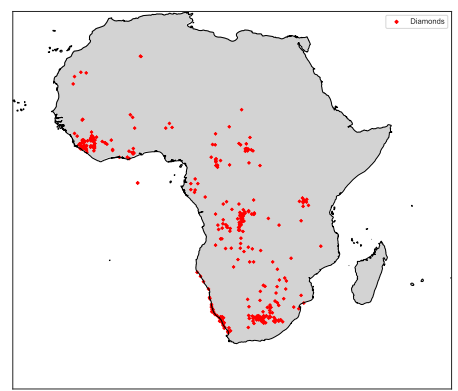

(c) Diamonds

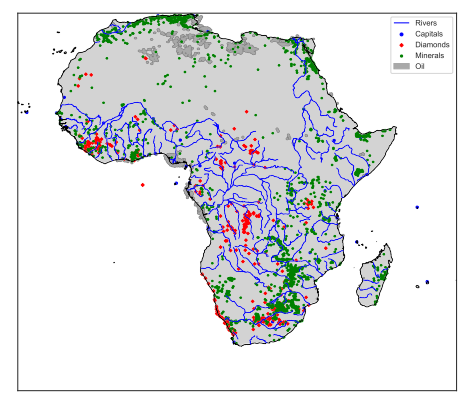

(f) All

Figure A.5: Location of Other Potential Determinants 


\section{B A Model of Ethnic Borders}

This section presents a model of ethnic border formation. The model provides a framework for predicting the location of borders in a world where geography, institutions, culture and history do not matter. Thus, giving us a framework for the construction of a theoretical instrumental variable for the location of ethnic borders, which we use in the empirical analysis. The model is similar to the one presented in Spolaore (2009), but generalizes it by allowing for a larger number of ethnic groups, a higher dimensional geographical space, and an endogenous choice of location by each population.

\section{B.1 Basic Setup}

Consider a world with three ethnic groups $(A, B, C)$ of equal size, normalized to 1 . Each ethnicity $i$ decides simultaneously its homeland's center $x_{i}$ in a circular world $X$ of size $3 R$. Given these locations, each ethnic group $i$ decides the amount of territory around $x_{i}$ it wants to control. Let $T_{i}$ denote the size of ethnicity $i$ 's territory, so that

$$
T_{A}+T_{B}+T_{C}=3 R
$$

The territory between any pair of ethnicities $i$ and $j$ is valuable to them since it contains resources (land, water, other natural resources) that can be used by either one of them to produce output. We assume that this territory is of economic interest only to $i$ and $j$, so that only these two neighboring populations have an incentive to exploit and control it. This assumption is equivalent to assuming that weapon technology is such that ethnicities can only exert control on areas that are contiguos to their center location. Since we are interested in modeling conditions in Africa during the pre-colonial era, this does not seem too strong an assumption. Without loss of generality, we assume that each unit of territory produces 1 unit of output. Thus, the amount of output that can be produced on the territory between any pair of ethnicities is equal to its size $R_{i j}$. Thus,

$$
R_{A B}+R_{B C}+R_{C A}=3 R .
$$

Figure B.1 depicts the world for a given set of location choices and territorial control.

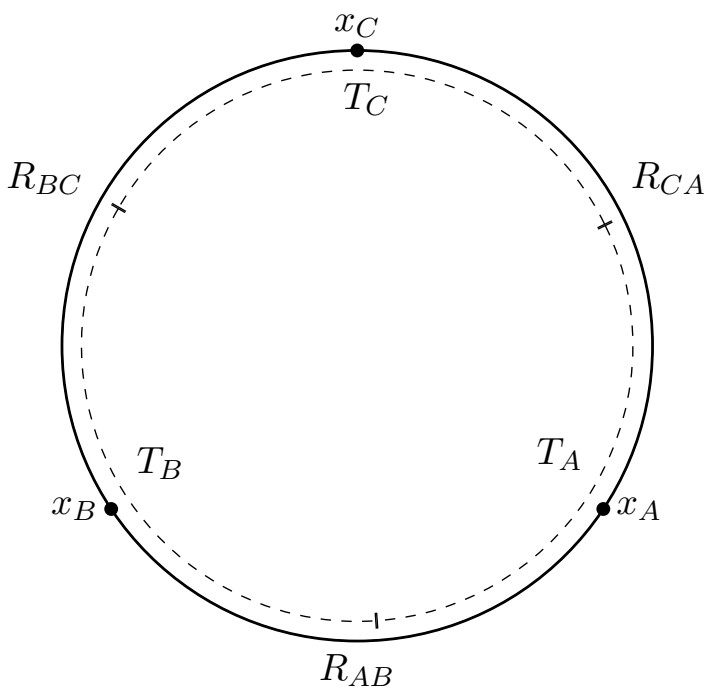

Figure B.1: A world with three ethnicities

In order to control some territory, each ethnicity needs to spend resources to build their military 
capabilities (i.e., weapons). Ethnicities allocate the output of their territory between consumption $\left(C_{i}\right)$ and weapons $\left(W_{i}\right)$. Thus, each ethnicity's consumption is

$$
C_{i}=T_{i}-W_{i}
$$

We assume that weapons are not easily mobile and thus ethnicities allocate weapons to each region they want to control. Thus, the total number of weapons built by ethnicity $i$ is

$$
W_{i}=W_{i j}+W_{i k}
$$

where $W_{i j}$ is the amount of weapons built to control the territory between $i$ and $j$, and similarly $W_{i k}$ is the amount of weapons built to control the territory between $i$ and $k$. The territory located between any pair of ethnicities $i$ and $j, R_{i j}$, is divided between them in proportion of their military strength. In particular, following the literature on the subject, we assume that if ethnicity $i$ has an amount of weapons $W_{i j}$ and ethnicity $j$ and amount $W_{j i}$ at its disposal in the territory between them, then the share of the territory controlled by ethnicity $i$ is

$$
P\left(W_{i j}, W_{j i}\right)=\frac{W_{i j}}{W_{i j}+W_{j i}}
$$

Clearly, this contest success function $P\left(W_{i j}, W_{j i}\right)$ is increasing in $W_{i j}$ and decreasing in $W_{j i}$. While $P\left(W_{i j}, W_{j i}\right)$ can be interpreted as the probability that ethnicity $i$ wins control of the whole territory if there was a conflict between $i$ and $j$, we assume instead that it reflects the amount of territory each ethnicity naturally dominates given their own and their neighbor's military strength. One possible interpretation is that territorial division between $i$ and $j$ occurs under the threat of conflict, and each obtains a share equal to the one they expect to gain in case of conflict. Clearly, if the spatial reallocation of weapons is costly or if their spatial reach is limited, then ethnicities would locate them at the border in order to protect their homeland. This would explain why conflict should be expected to occur at border locations. Another interpretation is that in each point of the region a small conflict over that piece of territory occurs with the winner of the contest keeping control of that piece of territory. While the ex-post distribution of territory may differ with the one presented below, the ex-ante distribution of territory, as well as allocations of consumption and weapons would be identical. Unlike the previous interpretation, conflict would be expected to be more uniformly distributed. Nonetheless, ethnic homelands would not be expected to be convex sets, making their definition more problematic, especially in an ex-post sense.

We assume that all individuals in each ethnicity $i$ have identical risk neutral preferences over consumption $C_{i}$. Thus, the optimal weapons and consumption choices of ethnicity $i$ 's representative agent maximize her expected utility, i.e. they solve the following problem:

$$
\max \frac{W_{i j}}{W_{i j}+W_{j i}} R_{i j}+\frac{W_{i k}}{W_{i k}+W_{k i}} R_{i k}-W_{i j}-W_{i k} .
$$

\section{B.2 Equilibrium}

Clearly, her choice $W_{i j}$ is independent of her choice $W_{i k}$ and so we analyze the solution for each pair of ethnicities independently at this stage. In particular, her best response to ethnicity $j$ 's weapon choice is

$$
W_{i j}=\sqrt{R_{i j} W_{j i}}-W_{j i}
$$


This implies that the equilibrium allocation of weapons for ethnicities $i$ and $j$ is

$$
\left(W_{i j}^{*}, W_{j i}^{*}\right)=\left(\frac{R_{i j}}{4}, \frac{R_{i j}}{4}\right),
$$

so that each controls half the territory $R_{i j}$. By a similar analysis we obtain that the equilibrium for ethnicities $i$ and $k$ is

$$
\left(W_{i k}^{*}, W_{k i}^{*}\right)=\left(\frac{R_{i k}}{4}, \frac{R_{i k}}{4}\right)
$$

and each controls half of the territory $R_{i k}$. Notice that ethnicities allocate more resources to the larger region. Still, the expected amount of conflict is similar in both regions. Importantly, each ethnicity controls the territory closest to its center, i.e. the optimal allocation of territories generates one-dimensional Voronoi regions. ${ }^{52}$ In particular, it follows that for each ethnicity $i$,

$$
T_{i}=\left\{x \in X \mid d\left(x, x_{i}\right) \leq d\left(x, x_{j}\right), j \neq i\right\}
$$

where $d\left(x, x_{i}\right)$ the notes the length of the arc between $x$ and $x_{i}$. This implies that the territories $T_{i}$ define a Voronoi partition of the world. The (Voronoi) border between ethnicity $i$ and $j, B_{i j}$, is given by the intersection between their territories, i.e., $B_{i j}=T_{i} \cap T_{j}$.

These results imply that the level of consumption of ethnicity $i$ is

$$
C_{i}=\frac{1}{4}\left(R_{i j}+R_{i k}\right)
$$

which is increasing in the distance of ethnicity $i$ 's center from the center of other two ethnicities. Thus, given the locational choice of $j$ and $k$, ethnicity $i$ 's best response is to choose a location $X_{i}$ on the circle, such that the regions $R_{i j}$ and $R_{i k}$ satisfy

$$
R_{i j}+R_{i k} \geq \max \left\{R_{j k}^{+}, R_{j k}^{-}\right\}
$$

where $R_{j k}^{+}$is the length of the arc that connects $j$ and $k$ clockwise and $R_{j k}^{-}$counter-clockwise. So, in a Nash equilibrium, all locations, $x_{A}, x_{B}$, and $x_{C}$ satisfy condition (14). It is not difficult to see that the set of Nash equilibria is a continuum, since given a set of Nash equilibrium locations, a rotation around the center of the circle is also an equilibrium. Even if one were to define classes of Nash equilibria based on the angles defining $R_{A B}^{+}, R_{B C}^{+}$and $R_{C A}^{+}$, there still exist a continuum of these classes, since given the location of two ethnicities in one of these classes, one can perturb the location of the third and still be in a Nash equilibrium. Nevertheless, there exists a unique class of symmetric Nash equilibria, in which the locations of all ethnicities are such that each is at a distance $R$ from the other. ${ }^{53}$ In this

\footnotetext{
${ }^{52}$ Letting $X$ be a metric space with associated metric $d$, given a set of $N$ points, $P=\left\{p_{1}, \ldots, p_{N}\right\}$, the Voronoi region associated with point $p_{i}, V_{i}$, is defined by$$
V_{i}=\left\{x \in X \mid d\left(x, p_{i}\right) \leq d\left(x, p_{j}\right), j \neq i\right\} .
$$

${ }^{53}$ If locations were chosen sequentially instead of simultaneously, there would be a unique subclass of Nash equilibria, in which the first ethnicity chooses any location on the circle, the second chooses the location directly on the opposite side of the first ethnicity, and the third ethnicity chooses any location between the other two. Thus, e.g., the locations behind the symmetric Nash equilibrium, which has been employed as starting point in many analyses in the literature, would not generate Nash equilibria in this variation of the model.
} 
class of symmetric Nash equilibria, the levels of consumption, weapons and territory are

$$
\begin{aligned}
C_{A} & =C_{B}=C_{C}=\frac{R}{2}, \\
W_{A B} & =W_{A C}=W_{B A}=W_{B C}=W_{C A}=W_{C B}=\frac{R}{4}, \\
R_{A B} & =R_{B C}=R_{C A}=R .
\end{aligned}
$$

\section{B.3 Generalizations}

While the previous model is quite specialized given its assumption of only three ethnicities on a circle, it is not difficult to generalize it to consider more interesting settings. First, notice that increasing the number of ethnicities to $N>3$ on a circle does not affect the optimal weapon allocations for each pair of ethnicities. Thus, equilibrium weapon allocations and borders are similar to the $N=3$ case. Thus, equilibrium territories in this case would still define a Voronoi partition of the circle. Similarly, the optimal location for ethnicity $i$ would satisfy a more general version of equation (14). Specifically, the best response of ethnicity $i$ to the location of all other $N-1$ ethnicities has to satisfy

$$
R_{i \hat{j}}+R_{i \hat{k}} \geq \max \left\{R_{j k}^{+}, R_{j k}^{-}\right\}
$$

for all $j, k \neq i$, where $\hat{j}$ and $\hat{k}$ are the ethnicities between which ethnicity $i$ chooses to locate. Clearly, the set of Nash equilibria is non-empty and non-unique, since the class of symmetric Nash equilibria, in which $R_{i j}=\hat{R}=3 R / N$ for all $i, j$ is non-empty.

Second, let's generalize the geographical space. In particular, consider the case of $N=3$ ethnicities on a 2-dimensional sphere $X$. As in the previous section, we assume that ethnicities can only control regions of the sphere located close to them. Thus, let

$$
R_{i j}=\left\{x \in X \mid d\left(x, x_{i}\right) \leq d\left(x, x_{k}\right) \text { and } d\left(x, x_{j}\right) \leq d\left(x, x_{k}\right)\right\}
$$

be the region of the sphere that is closer to $i$ and $j$ than to $k \cdot{ }^{54}$ Clearly, the results of the previous section generalize mutatis mutandis to this setting. Specifically, the optimal choices of weapons would remain unchanged and would imply a Voronoi partition of the sphere based on the location of the ethnicities. Moreover, the location of each ethnicity $i$ has to ensure that the area of $R_{i j}$ and $R_{i k}$ satisfies equation (14), where $R_{j k}^{+}$and $R_{j k}^{-}$are the areas of the half-spheres defined by the location of ethnicities $j$ and $k$.

Finally, it should be clear that we can generalize this last result to $N>3$ ethnicities and $n>2$ dimensional spheres following a similar procedure to the previous two generalizations. Moreover, since we have worked with an unspecified metric $d$, it is clear that the choice of metric plays no role in the results.

\section{Dataset $50 \times 50$}

\section{C.1 Additional Results}

In Table C.18 we use UCDP GED dataset by PRIO which allows us to look at multiple additional dimensions of conflict. Firstly, we can restrict our analysis to a very well defined characterization of conflict since the UCDP GED dataset is restricted to events involving fatalities and adheres to the general and well established definitions given in the UCDP-PRIO Armed Conflict Dataset, which has

\footnotetext{
${ }^{54}$ On a circle, the arc between the location of $i$ and $j$ satisfies a similar property.
} 
been extensively used in the conflict literature. ${ }^{55}$ Secondly, we can also identified whether a conflict event involves the government (i.e., state-based) or just local groups (i.e., communal). Thirdly, we can identified the location of the first confrontation within a dyad to compute prevalence and intensity measures of conflict onset. In addition, using UCDP GED dataset provides a key robustness check to reassure that our results are not driven by a particular conflict dataset.

In column 1 of Table C.18 we show that conflict prevalence based on UCDP GED is also highly concentrated in grids intersected by historical ethnic borders. We reach to the same conclusion regardless we look at state-based (column 2) or communal conflict (column 3). Further, hosting a historical ethnic border increases the likelihood of having a conflict onset in 6.8 percent, which represents 170 percent of its mean prevalence (column 4). Finally, the semi-elasticity estimated in column 5 suggests that the number of conflict onset increases by 6.4 percent at the historical ethnic borders.

\section{C.1.1 Intensive Measures - OLS Results}

Table C.1: Historical Ethnic Borders and Conflict (OLS)

\begin{tabular}{llll}
\hline \hline & \multicolumn{3}{c}{ Prevalence of Conflict } \\
\cline { 2 - 4 } & \multicolumn{1}{c}{$(1)$} & $(2)$ & $(3)$ \\
\hline Presence of Ethnic Border & $0.059^{* * *}$ & & \\
Length of Ethnic Borders (Logs) & & & \\
& & $0.015)$ & \\
Number of Ethnic Borders (Logs) & & $(0.004)$ & \\
& & & $0.098^{* * * *}$ \\
Country FE & Yes & Yes & Yes \\
Ethnic FE & Yes & Yes & Yes \\
Main Controls & Yes & Yes & Yes \\
Adjusted- $R^{2}$ & 0.32 & 0.33 & 0.32 \\
Observations & 14078 & 14078 & 14078 \\
\hline
\end{tabular}

Notes: Heteroskedasticity robust standard error estimates clustered at the country-level are reported in parentheses; $* * *$ denotes statistical significance at the $1 \%$ level, $* *$ at the $5 \%$ level, and * at the $10 \%$ level, all for two-sided hypothesis tests. Main Controls refer to the sets of Geographic and Climatic controls described in Table 1.

\footnotetext{
${ }^{55} \mathrm{~A}$ conflict event is defined as "the incidence of the use of armed force by an organized actor against another organized actor, or against civilians, resulting in at least one direct death" (see Sundberg et al. 2010)) CITATION. More importantly, UCDP GED traces all the conflict events of all dyads and actors that have crossed the 25-deaths threshold in any year of the UCDP annual data (Depetris-Chauvin, 2014)
} 
Table C.2: Historical Ethnic Borders and Conflict (OLS)

\begin{tabular}{|c|c|c|c|c|c|c|}
\hline & \multicolumn{6}{|c|}{ Conflict Intensity } \\
\hline & \multicolumn{2}{|c|}{ Events } & \multicolumn{2}{|c|}{ Years } & \multicolumn{2}{|c|}{ Fatalities } \\
\hline & (1) & $(2)$ & $(3)$ & $(4)$ & $(5)$ & $(6)$ \\
\hline Length of Ethnic Borders (Logs) & $\begin{array}{l}0.045^{* * *} \\
(0.008)\end{array}$ & & $\begin{array}{l}0.004^{* * *} \\
(0.001)\end{array}$ & & $\begin{array}{l}0.026^{* * *} \\
(0.008)\end{array}$ & \\
\hline Number of Ethnic Borders (Logs) & & $\begin{array}{l}0.246^{* * *} \\
(0.057)\end{array}$ & & $\begin{array}{l}0.024^{* * *} \\
(0.005)\end{array}$ & & $\begin{array}{l}0.150^{* *} \\
(0.062)\end{array}$ \\
\hline Country FE & Yes & Yes & Yes & Yes & Yes & Yes \\
\hline Ethnic FE & Yes & Yes & Yes & Yes & Yes & Yes \\
\hline Main Controls & Yes & Yes & Yes & Yes & Yes & Yes \\
\hline Adjusted- $R^{2}$ & 0.37 & 0.37 & 0.36 & 0.36 & 0.34 & 0.34 \\
\hline Observations & 14078 & 14078 & 14078 & 14078 & 14078 & 14078 \\
\hline
\end{tabular}

Notes: Heteroskedasticity robust standard error estimates clustered at the country-level are reported in parentheses; *** denotes statistical significance at the $1 \%$ level, ** at the $5 \%$ level, and * at the $10 \%$ level, all for two-sided hypothesis tests. Main Controls refer to the sets of Geographic and Climatic controls described in Table 1. 


\section{C.2 Using Alternative Ethnic Map - GREG}

Table C.3: Historical Ethnic Borders (GREG) and Conflict (OLS)

\begin{tabular}{|c|c|c|c|c|c|c|c|c|}
\hline & \multicolumn{8}{|c|}{ Conflict } \\
\hline & \multicolumn{5}{|c|}{ Prevalence } & \multicolumn{3}{|c|}{ Intensity } \\
\hline & \multicolumn{5}{|c|}{ Presence } & Events & Years & Fatalities \\
\hline & (1) & $(2)$ & $(3)$ & (4) & $(5)$ & $(6)$ & $(7)$ & $(8)$ \\
\hline Presence of Ethnic Borders (GREG) & $\begin{array}{l}0.124^{* * *} \\
(0.027)\end{array}$ & $\begin{array}{l}0.083^{* * *} \\
(0.020)\end{array}$ & $\begin{array}{l}0.047^{* * *} \\
(0.014)\end{array}$ & $\begin{array}{l}0.044^{* * *} \\
(0.013)\end{array}$ & $\begin{array}{l}0.041^{* * *} \\
(0.013)\end{array}$ & $\begin{array}{l}0.093^{* * *} \\
(0.024)\end{array}$ & $\begin{array}{l}0.008^{* * *} \\
(0.002)\end{array}$ & $\begin{array}{l}0.076^{* * *} \\
(0.021)\end{array}$ \\
\hline Country FE & No & Yes & Yes & Yes & Yes & Yes & Yes & Yes \\
\hline Ethnic FE & No & No & Yes & Yes & Yes & Yes & Yes & Yes \\
\hline Geographic Controls & No & No & No & Yes & Yes & Yes & Yes & Yes \\
\hline Climatic Controls & No & No & No & No & Yes & Yes & Yes & Yes \\
\hline Adjusted- $R^{2}$ & 0.02 & 0.18 & 0.31 & 0.32 & 0.32 & 0.37 & 0.36 & 0.34 \\
\hline Observations & 14078 & 14078 & 14078 & 14078 & 14078 & 14078 & 14078 & 14078 \\
\hline
\end{tabular}

Notes: Heteroskedasticity robust standard error estimates clustered at the country-level are reported in parentheses; denotes statistical significance at the $1 \%$ level, at the $5 \%$ level, and at the $10 \%$ level, all for two-sided hypothesis tests.

Table C.4: Murdock's Ethnic Borders and Voronoi Ethnic Borders Instrumental Variable Analysis (First-Stage)

\begin{tabular}{|c|c|c|c|c|c|c|c|}
\hline & \multicolumn{7}{|c|}{ Presence of Ethnic Border } \\
\hline & Murdock & Atlas & EA & GREG & CSI & CSIMEAN & CSITOT \\
\hline & $(1)$ & $(2)$ & $(3)$ & $(4)$ & $(5)$ & (6) & (7) \\
\hline \multicolumn{8}{|l|}{ Panel A: No Controls } \\
\hline Presence of Voronoi Border & $\begin{array}{c}0.239 * * * \\
(0.021)\end{array}$ & $\begin{array}{c}0.262^{* * *} \\
(0.026)\end{array}$ & $\begin{array}{c}0.244^{* * *} \\
(0.026)\end{array}$ & $\begin{array}{c}0.255^{* * *} \\
(0.033)\end{array}$ & $\begin{array}{c}0.234^{* * *} \\
(0.021)\end{array}$ & $\begin{array}{c}0.228^{* * *} \\
(0.023)\end{array}$ & $\begin{array}{c}0.228^{* * *} \\
(0.023)\end{array}$ \\
\hline \multicolumn{8}{|l|}{ Panel B: Fixed Effects } \\
\hline Presence of Voronoi Border & $\begin{array}{c}0.105^{* * *} \\
(0.025)\end{array}$ & $\begin{array}{c}0.122^{* * *} \\
(0.024)\end{array}$ & $\begin{array}{c}0.133^{* * *} \\
(0.026)\end{array}$ & $\begin{array}{c}0.140^{* * *} \\
(0.031)\end{array}$ & $\begin{array}{c}0.111^{* * *} \\
(0.020)\end{array}$ & $\begin{array}{c}0.098 * * * \\
(0.021)\end{array}$ & $\begin{array}{c}0.098 * * * \\
(0.021)\end{array}$ \\
\hline \multicolumn{8}{|l|}{ Panel C: All Controls } \\
\hline Presence of Voronoid Border & $\begin{array}{c}0.092^{* * *} \\
(0.023)\end{array}$ & $\begin{array}{c}0.108^{* * *} \\
(0.022)\end{array}$ & $\begin{array}{c}0.119 * * * \\
(0.024)\end{array}$ & $\begin{array}{c}0.127^{* * *} \\
(0.029)\end{array}$ & $\begin{array}{c}0.099 * * * \\
(0.018)\end{array}$ & $\begin{array}{c}0.084^{* * *} \\
(0.019)\end{array}$ & $\begin{array}{c}0.084^{* * *} \\
(0.019)\end{array}$ \\
\hline
\end{tabular}

Notes: Heteroskedasticity robust standard error estimates clustered at the country-level are reported in parentheses; *** denotes statistical significance at the $1 \%$ level, $* *$ at the $5 \%$ level, and $*$ at the $10 \%$ level, all for two-sided hypothesis tests. 
Table C.5: Historical Ethnic Borders and Conflict (IV) Robustness to Centroid Choice

\begin{tabular}{|c|c|c|c|c|c|c|c|}
\hline & \multicolumn{7}{|c|}{ Conflict Prevalence } \\
\hline & Murdock & Atlas & EA & GREG & CSI & CSIMEAN & CSITOT \\
\hline & (1) & $(2)$ & $(3)$ & $(4)$ & $(5)$ & (6) & $(7)$ \\
\hline \multicolumn{8}{|l|}{ Panel A: No Controls } \\
\hline Presence of Ethnic Borders (GREG) & $\begin{array}{c}0.521^{* * *} \\
(0.090)\end{array}$ & $\begin{array}{c}0.487 * * * \\
(0.077)\end{array}$ & $\begin{array}{c}0.517 * * * \\
(0.101)\end{array}$ & $\begin{array}{c}0.396^{* * *} \\
(0.084)\end{array}$ & $\begin{array}{c}0.540^{* * *} \\
(0.093)\end{array}$ & $\begin{array}{c}0.528^{* * *} \\
(0.097)\end{array}$ & $\begin{array}{c}0.528^{* * *} \\
(0.097)\end{array}$ \\
\hline \multicolumn{8}{|l|}{ Panel B: Fixed Effects } \\
\hline Presence of Ethnic Borders (GREG) & $\begin{array}{c}0.326^{* * *} \\
(0.088)\end{array}$ & $\begin{array}{c}0.312^{* * *} \\
(0.078)\end{array}$ & $\begin{array}{c}0.376^{* * *} \\
(0.096)\end{array}$ & $\begin{array}{c}0.181^{* *} \\
(0.079)\end{array}$ & $\begin{array}{c}0.339^{* * *} \\
(0.094)\end{array}$ & $\begin{array}{c}0.312^{* * *} \\
(0.105)\end{array}$ & $\begin{array}{c}0.312^{* * *} \\
(0.105)\end{array}$ \\
\hline \multicolumn{8}{|l|}{ Panel C: All Controls } \\
\hline Presence of Ethnic Borders (GREG) & $\begin{array}{c}0.318^{* * * *} \\
(0.090)\end{array}$ & $\begin{array}{c}0.295^{* * *} \\
(0.082)\end{array}$ & $\begin{array}{c}0.377^{* * *} \\
(0.098)\end{array}$ & $\begin{array}{c}0.167^{* *} \\
(0.080)\end{array}$ & $\begin{array}{c}0.333^{* * *} \\
(0.098)\end{array}$ & $\begin{array}{c}0.315^{* * *} \\
(0.115)\end{array}$ & $\begin{array}{c}0.315^{* * *} \\
(0.115)\end{array}$ \\
\hline
\end{tabular}

Notes: Heteroskedasticity robust standard error estimates clustered at the country-level are reported in parentheses; *** denotes statistical significance at the $1 \%$ level, ${ }^{* *}$ at the $5 \%$ level, and $*$ at the $10 \%$ level, all for two-sided hypothesis tests. 


\section{C.2.1 Robustness to Sampling - OLS}

Table C.6: Historical Ethnic Borders and Conflict (OLS) Robustness to Sample

\begin{tabular}{|c|c|c|c|c|c|c|c|c|}
\hline & \multicolumn{8}{|c|}{ Prevalence of Conflict } \\
\hline & \multirow[b]{2}{*}{ Full } & \multicolumn{7}{|c|}{ Exclude } \\
\hline & & Magreb & COD & KEN & NGA & SLE & SOM & $\mathrm{ZAF}$ \\
\hline & (1) & $(2)$ & $(3)$ & $(4)$ & $(5)$ & (6) & (7) & $(8)$ \\
\hline Presence of Ethnic Border & $\begin{array}{l}0.059^{* * *} \\
(0.015)\end{array}$ & $\begin{array}{l}0.046^{* * *} \\
(0.016)\end{array}$ & $\begin{array}{l}0.058^{* * *} \\
(0.016)\end{array}$ & $\begin{array}{l}0.058^{* * *} \\
(0.015)\end{array}$ & $\begin{array}{l}0.060 * * * \\
(0.015)\end{array}$ & $\begin{array}{l}0.057^{* * *} \\
(0.015)\end{array}$ & $\begin{array}{l}0.068^{* * *} \\
(0.012)\end{array}$ & $\begin{array}{l}0.061^{* * *} \\
(0.015)\end{array}$ \\
\hline Country FE & Yes & Yes & Yes & Yes & Yes & Yes & Yes & Yes \\
\hline Ethnic FE & Yes & Yes & Yes & Yes & Yes & Yes & Yes & Yes \\
\hline Main Controls & Yes & Yes & Yes & Yes & Yes & Yes & Yes & Yes \\
\hline Adjusted- $R^{2}$ & 0.32 & 0.30 & 0.34 & 0.32 & 0.30 & 0.32 & 0.32 & 0.32 \\
\hline Observations & 14078 & 11105 & 13035 & 13801 & 13656 & 14033 & 13762 & 13503 \\
\hline
\end{tabular}

Notes: Heteroskedasticity robust standard error estimates clustered at the country-level are reported in parentheses; *** denotes statistical significance at the $1 \%$ level, ** at the $5 \%$ level, and $*$ at the $10 \%$ level, all for two-sided hypothesis tests. Main Controls refer to the sets of Geographic and Climatic controls described in Table 1.

\section{C.2.2 Intensive Measures - First Stage}

Table C.7: Murdock's Ethnic Borders and Voronoi Ethnic Borders Instrumental Variable Analysis (First-Stage)

\begin{tabular}{|c|c|c|c|c|c|c|c|c|c|}
\hline & \multicolumn{9}{|c|}{ Ethnic Border } \\
\hline & \multicolumn{3}{|c|}{ Presence } & \multicolumn{3}{|c|}{ Length } & \multicolumn{3}{|c|}{ Number } \\
\hline & (1) & $(2)$ & $(3)$ & $(4)$ & $(5)$ & (6) & $(7)$ & $(8)$ & $(9)$ \\
\hline Presence of Voronoi Border & $\begin{array}{l}0.107^{* * *} \\
(0.018)\end{array}$ & & & $\begin{array}{l}0.463^{* * *} \\
(0.068)\end{array}$ & & & $\begin{array}{l}0.076^{* * *} \\
(0.013)\end{array}$ & & \\
\hline Length of Voronoi Borders (Logs) & & $\begin{array}{l}0.021^{* * *} \\
(0.004)\end{array}$ & & & $\begin{array}{l}0.108^{* * *} \\
(0.015)\end{array}$ & & & $\begin{array}{l}0.015^{* * *} \\
(0.002)\end{array}$ & \\
\hline Number of Voronoi Borders (Logs) & & & $\begin{array}{l}0.079^{* * *} \\
(0.015)\end{array}$ & & & $\begin{array}{l}0.362^{* * *} \\
(0.058)\end{array}$ & & & $\begin{array}{l}0.064^{* * *} \\
(0.011)\end{array}$ \\
\hline Country FE & Yes & Yes & Yes & Yes & Yes & Yes & Yes & Yes & Yes \\
\hline Ethnic FE & Yes & Yes & Yes & Yes & Yes & Yes & Yes & Yes & Yes \\
\hline Main Controls & Yes & Yes & Yes & Yes & Yes & Yes & Yes & Yes & Yes \\
\hline Adjusted- $R^{2}$ & 0.71 & 0.70 & 0.70 & 0.74 & 0.74 & 0.74 & 0.89 & 0.88 & 0.88 \\
\hline Observations & 14078 & 14078 & 14078 & 14078 & 14078 & 14078 & 14078 & 14078 & 14078 \\
\hline
\end{tabular}


Table C.8: Murdock's Ethnic Borders and Voronoi Ethnic Borders Instrumental Variable Analysis (First-Stage)

\begin{tabular}{|c|c|c|c|c|c|}
\hline & \multicolumn{5}{|c|}{ Presence of Ethnic Border } \\
\hline & $(1)$ & $(2)$ & $(3)$ & $(4)$ & $(5)$ \\
\hline Number of Voronoi Borders (Logs) & $\begin{array}{l}0.305^{* * *} \\
(0.015)\end{array}$ & $\begin{array}{l}0.250^{* * *} \\
(0.016)\end{array}$ & $\begin{array}{l}0.094^{* * *} \\
(0.018)\end{array}$ & $\begin{array}{l}0.082^{* * *} \\
(0.016)\end{array}$ & $\begin{array}{l}0.079 * * * \\
(0.015) \\
(0.005)\end{array}$ \\
\hline Country FE & No & Yes & Yes & Yes & Yes \\
\hline Ethnic FE & No & No & Yes & Yes & Yes \\
\hline Geographic Controls & No & No & No & Yes & Yes \\
\hline Climatic Controls & No & No & No & No & Yes \\
\hline Adjusted- $R^{2}$ & 0.10 & 0.14 & 0.67 & 0.69 & 0.70 \\
\hline Observations & 14078 & 14078 & 14078 & 14078 & 14078 \\
\hline
\end{tabular}

Notes: Heteroskedasticity robust standard error estimates clustered at the country-level are reported in parentheses; *** denotes statistical significance at the $1 \%$ level, $* *$ at the $5 \%$ level, and * at the $10 \%$ level, all for two-sided hypothesis tests. The sets of Geographic and Climatic controls are described in Table 1.

Table C.9: Murdock's Ethnic Borders and Voronoi Ethnic Borders Instrumental Variable Analysis (First-Stage)

\begin{tabular}{|c|c|c|c|c|c|}
\hline & \multicolumn{5}{|c|}{ Presence of Ethnic Border } \\
\hline & (1) & $(2)$ & $(3)$ & $(4)$ & $(5)$ \\
\hline Length of Voronoi Borders (Logs) & $\begin{array}{l}0.073^{* * *} \\
(0.004)\end{array}$ & $\begin{array}{l}0.061^{* * *} \\
(0.004)\end{array}$ & $\begin{array}{l}0.025^{* * *} \\
(0.004)\end{array}$ & $\begin{array}{l}0.022^{* * *} \\
(0.004)\end{array}$ & $\begin{array}{l}0.021^{* * *} \\
(0.004)\end{array}$ \\
\hline Country FE & No & Yes & Yes & Yes & Yes \\
\hline Ethnic FE & No & No & Yes & Yes & Yes \\
\hline Geographic Controls & No & No & No & Yes & Yes \\
\hline Climatic Controls & No & No & No & No & Yes \\
\hline Adjusted- $R^{2}$ & 0.10 & 0.15 & 0.68 & 0.69 & 0.70 \\
\hline Observations & 14078 & 14078 & 14078 & 14078 & 14078 \\
\hline
\end{tabular}

Notes: Heteroskedasticity robust standard error estimates clustered at the country-level are reported in parentheses; *** denotes statistical significance at the $1 \%$ level, ${ }^{* *}$ at the $5 \%$ level, and * at the $10 \%$ level, all for two-sided hypothesis tests. The sets of Geographic and Climatic controls are described in Table 1. 


\section{C.2.3 Prevalence and Intensity of Conflict - IV}

Table C.10: Historical Ethnic Borders and Conflict (IV)

\begin{tabular}{|c|c|c|c|c|c|c|c|}
\hline & \multicolumn{7}{|c|}{ Conflict } \\
\hline & \multicolumn{4}{|c|}{ Prevalence } & \multicolumn{3}{|c|}{ Intensity } \\
\hline & \multicolumn{4}{|c|}{ Presence } & \multirow{2}{*}{$\frac{\text { Events }}{(5)}$} & \multirow{2}{*}{$\frac{\text { Years }}{(6)}$} & \multirow{2}{*}{$\frac{\text { Fatalities }}{(7)}$} \\
\hline & $(1)$ & $(2)$ & (3) & $(4)$ & & & \\
\hline Presence of Ethnic Border & $\begin{array}{l}0.382^{* * *} \\
(0.066)\end{array}$ & $\begin{array}{l}0.282^{* * *} \\
(0.041)\end{array}$ & $\begin{array}{l}0.274^{* * *} \\
(0.064)\end{array}$ & $\begin{array}{l}0.273^{* * *} \\
(0.066)\end{array}$ & $\begin{array}{l}0.534^{* * *} \\
(0.136)\end{array}$ & $\begin{array}{l}0.044^{* * *} \\
(0.014)\end{array}$ & $\begin{array}{l}0.519^{* * *} \\
(0.128)\end{array}$ \\
\hline Country FE & No & Yes & Yes & Yes & Yes & Yes & Yes \\
\hline Ethnic FE & No & No & Yes & Yes & Yes & Yes & Yes \\
\hline Main Controls & No & No & No & Yes & Yes & Yes & Yes \\
\hline First-stage F-statistic & 319.16 & 207.65 & 35.03 & 34.14 & 34.14 & 34.14 & 34.14 \\
\hline Adjusted- $R^{2}$ & -0.06 & 0.13 & 0.30 & 0.30 & 0.35 & 0.35 & 0.32 \\
\hline Observations & 14078 & 14078 & 14078 & 14078 & 14078 & 14078 & 14078 \\
\hline
\end{tabular}

Notes: Heteroskedasticity robust standard error estimates clustered at the country-level are reported in parentheses; $* * *$ denotes statistical significance at the $1 \%$ level, ** at the $5 \%$ level, and * at the $10 \%$ level, all for two-sided hypothesis tests. Main Controls refer to the sets of Geographic and Climatic controls described in Table 1. 


\section{C.2.4 Robustness to Intensive Voronoi Border Measures - IV}

Table C.11: Historical Ethnic Borders and Conflict (IV)

\begin{tabular}{llccccc}
\hline \hline & \multicolumn{5}{c}{ Prevalence of Conflict } \\
\cline { 2 - 7 } & \multicolumn{1}{c}{$(1)$} & $(2)$ & $(3)$ & $(4)$ & $(5)$ & $(6)$ \\
\hline Presence of Ethnic Border & $0.470^{* * *}$ & $0.476^{* * *}$ & $0.506^{* * *}$ & $0.402^{* * *}$ & $0.360^{* * *}$ & $0.361^{* * *}$ \\
& $(0.089)$ & $(0.139)$ & $(0.161)$ & $(0.070)$ & $(0.074)$ & $(0.079)$ \\
\hline Instrument & Number of Voronoi Borders & Voronoi Border Length \\
\hline Country FE & No & Yes & Yes & No & Yes & Yes \\
Ethnic FE & No & Yes & Yes & No & Yes & Yes \\
Main Controls & No & No & Yes & No & No & Yes \\
First-stage F-statistic & 288.76 & 19.38 & 19.02 & 324.09 & 36.42 & 35.49 \\
Adjusted- $R^{2}$ & -0.13 & 0.24 & 0.23 & -0.07 & 0.28 & 0.28 \\
Observations & 14078 & 14078 & 14078 & 14078 & 14078 & 14078 \\
\hline
\end{tabular}

Notes: Heteroskedasticity robust standard error estimates clustered at the country-level are reported in parentheses; $* * *$ denotes statistical significance at the $1 \%$ level, ${ }^{* *}$ at the $5 \%$ level, and $*$ at the $10 \%$ level, all for two-sided hypothesis tests. Main Controls refer to the sets of Geographic and Climatic controls described in Table 1. 


\section{C.2.5 Robustness to Sampling, Clustering, Spatial Auto-correlation - IV}

Table C.12: Historical Ethnic Borders and Conflict Robustness to Spatial-Autocorrelation

\begin{tabular}{|c|c|c|c|c|c|c|}
\hline & \multicolumn{6}{|c|}{ Prevalence of Conflict } \\
\hline & \multicolumn{3}{|c|}{ OLS } & \multicolumn{3}{|c|}{ IV } \\
\hline & (1) & $(2)$ & $(3)$ & (4) & $(5)$ & $(6)$ \\
\hline \multirow[t]{6}{*}{ Presence of Ethnic Border } & $0.137^{* * *}$ & $0.072^{* * *}$ & $0.059^{* * *}$ & $0.382^{* * *}$ & $0.274^{* * *}$ & $0.273^{* * *}$ \\
\hline & $(0.022)$ & $(0.016)$ & $(0.014)$ & $(0.066)$ & $(0.064)$ & $(0.066)$ \\
\hline & {$[0.015]$} & {$[0.014]$} & [0.013] & {$[0.036]$} & {$[0.057]$} & {$[0.059]$} \\
\hline & $((0.020))$ & $((0.017))$ & $((0.014))$ & $((0.051))$ & $((0.063))$ & $((0.066))$ \\
\hline & {$[[0.023]$} & {$[[0.019]$} & {$[[0.016]$} & {$[[0.059]$} & [[0.071] & {$[[0.068]$} \\
\hline & $([0.026])$ & $([0.020])$ & $([0.009])$ & $([0.073])$ & $([0.066])$ & $([0.072])$ \\
\hline Country FE & No & Yes & Yes & No & Yes & Yes \\
\hline Ethnic FE & No & Yes & Yes & No & Yes & Yes \\
\hline Main Controls & No & No & Yes & No & No & Yes \\
\hline$R^{2}$ & 0.03 & 0.36 & 0.37 & -0.06 & 0.34 & 0.35 \\
\hline Observations & 14078 & 14078 & 14078 & 14078 & 14078 & 14078 \\
\hline
\end{tabular}

Notes: Heteroskedasticity robust standard error estimates clustered at the country-level are reported in parentheses, spatial auto-correlation corrected standard errors with distance cutoffs at 100, 200, 500 and $1000 \mathrm{kms}$. are shown below; *** denotes statistical significance at the $1 \%$ level, $*^{*}$ at the $5 \%$ level, and * at the $10 \%$ level, all for two-sided hypothesis tests. Main Controls refer to the sets of Geographic and Climatic controls described in Table 1 .

Table C.13: Historical Ethnic Borders and Conflict Robustness to Clustering at Ethnic-Level

\begin{tabular}{|c|c|c|c|c|c|c|}
\hline & \multicolumn{6}{|c|}{ Prevalence of Conflict } \\
\hline & \multicolumn{3}{|c|}{ OLS } & \multicolumn{3}{|c|}{ IV } \\
\hline & (1) & (2) & (3) & $(4)$ & $(5)$ & (6) \\
\hline Presence of Ethnic Border & $\begin{array}{l}0.137^{* * *} \\
(0.013)\end{array}$ & $\begin{array}{l}0.072^{* * *} \\
(0.014)\end{array}$ & $\begin{array}{l}0.059^{* * *} \\
(0.015)\end{array}$ & $\begin{array}{l}0.382^{* * *} \\
(0.032)\end{array}$ & $\begin{array}{l}0.274^{* * *} \\
(0.058)\end{array}$ & $\begin{array}{l}0.273^{* * *} \\
(0.065)\end{array}$ \\
\hline Country FE & No & Yes & Yes & No & Yes & Yes \\
\hline Ethnic FE & No & Yes & Yes & No & Yes & Yes \\
\hline Main Controls & No & No & Yes & No & No & Yes \\
\hline$R^{2}$ & 0.03 & 0.36 & 0.37 & -0.06 & 0.34 & 0.35 \\
\hline Observations & 14078 & 14078 & 14078 & 14078 & 14078 & 14078 \\
\hline
\end{tabular}

Notes: Heteroskedasticity robust standard error estimates clustered at the ethnic-level are reported in parentheses; *** denotes statistical significance at the $1 \%$ level, ** at the $5 \%$ level, and * at the $10 \%$ level, all for two-sided hypothesis tests. Main Controls refer to the sets of Geographic and Climatic controls described in Table 1. 
Table C.14: Historical Ethnic Borders and Conflict

Robustness to Two-way Clustering at the Country and Ethnic-Level

\begin{tabular}{|c|c|c|c|c|c|c|}
\hline & \multicolumn{6}{|c|}{ Prevalence of Conflict } \\
\hline & \multicolumn{3}{|c|}{ OLS } & \multicolumn{3}{|c|}{ IV } \\
\hline & (1) & $(2)$ & $(3)$ & $(4)$ & $(5)$ & (6) \\
\hline Presence of Ethnic Border & $\begin{array}{l}0.137^{* * *} \\
(0.023)\end{array}$ & $\begin{array}{l}0.072^{* * *} \\
(0.016)\end{array}$ & $\begin{array}{l}0.059^{* * *} \\
(0.016)\end{array}$ & $\begin{array}{l}0.382^{* * *} \\
(0.067)\end{array}$ & $\begin{array}{l}0.274^{* * *} \\
(0.065)\end{array}$ & $\begin{array}{l}0.273^{* * *} \\
(0.068)\end{array}$ \\
\hline Country FE & No & Yes & Yes & No & Yes & Yes \\
\hline Ethnic FE & No & Yes & Yes & No & Yes & Yes \\
\hline Main Controls & No & No & Yes & No & No & Yes \\
\hline$R^{2}$ & 0.03 & 0.36 & 0.37 & -0.06 & 0.34 & 0.35 \\
\hline Observations & 14078 & 14078 & 14078 & 14078 & 14078 & 14078 \\
\hline
\end{tabular}

Notes: Heteroskedasticity robust standard error estimates two-way clustered at the country and ethnic-level are reported in parentheses; $* * *$ denotes statistical significance at the $1 \%$ level, $* *$ at the $5 \%$ level, and * at the $10 \%$ level, all for two-sided hypothesis tests. Main Controls refer to the sets of Geographic and Climatic controls described in Table 1.

Table C.15: Historical Ethnic Borders and Conflict (IV) Robustness to Sample

\begin{tabular}{|c|c|c|c|c|c|c|c|c|}
\hline & \multicolumn{8}{|c|}{ Prevalence of Conflict } \\
\hline & \multirow[b]{2}{*}{ Full } & \multicolumn{7}{|c|}{ Exclude } \\
\hline & & Magreb & COD & KEN & NGA & SLE & $\mathrm{SOM}$ & $\mathrm{ZAF}$ \\
\hline & $(1)$ & $(2)$ & $(3)$ & $(4)$ & $(5)$ & (6) & $(7)$ & $(8)$ \\
\hline Presence of Ethnic Border & $\begin{array}{l}0.273^{* * *} \\
(0.066)\end{array}$ & $\begin{array}{l}0.269 * * * \\
(0.081)\end{array}$ & $\begin{array}{l}0.283^{* * *} \\
(0.068)\end{array}$ & $\begin{array}{l}0.269 * * * \\
(0.067)\end{array}$ & $\begin{array}{l}0.263^{* * *} \\
(0.066)\end{array}$ & $\begin{array}{l}0.263^{* * *} \\
(0.065)\end{array}$ & $\begin{array}{l}0.312^{* * *} \\
(0.064)\end{array}$ & $\begin{array}{l}0.287 * * * \\
(0.072)\end{array}$ \\
\hline Country FE & Yes & Yes & Yes & Yes & Yes & Yes & Yes & Yes \\
\hline Ethnic FE & Yes & Yes & Yes & Yes & Yes & Yes & Yes & Yes \\
\hline Main Controls & Yes & Yes & Yes & Yes & Yes & Yes & Yes & Yes \\
\hline First-stage F-statistic & 34.14 & 28.33 & 31.51 & 32.73 & 32.65 & 33.72 & 35.01 & 30.47 \\
\hline Adjusted- $R^{2}$ & 0.30 & 0.28 & 0.31 & 0.30 & 0.28 & 0.30 & 0.29 & 0.30 \\
\hline Observations & 14078 & 11105 & 13035 & 13801 & 13656 & 14033 & 13762 & 13503 \\
\hline
\end{tabular}

Notes: Heteroskedasticity robust standard error estimates clustered at the country-level are reported in parentheses; *** denotes statistical significance at the $1 \%$ level, ${ }^{* *}$ at the $5 \%$ level, and $*$ at the $10 \%$ level, all for two-sided hypothesis tests. Main Controls refer to the sets of Geographic and Climatic controls described in Table 1. 
Table C.16: Historical Ethnic Borders and Conflict (IV) Robustness to Excluding Split Ethnicities \& Split Neighbors

\begin{tabular}{|c|c|c|c|c|}
\hline & \multicolumn{4}{|c|}{ Prevalence of Conflict } \\
\hline & All & Split & Not Split & $\begin{array}{c}\text { Not Split Self \& } \\
\text { Neighbor }\end{array}$ \\
\hline & $(1)$ & $(2)$ & $(3)$ & (4) \\
\hline Presence of Ethnic Border & $\begin{array}{l}0.273^{* * *} \\
(0.066)\end{array}$ & $\begin{array}{l}0.422^{* * *} \\
(0.137)\end{array}$ & $\begin{array}{l}0.136^{* *} \\
(0.062)\end{array}$ & $\begin{array}{l}0.165^{* *} \\
(0.076)\end{array}$ \\
\hline Country FE & Yes & Yes & Yes & Yes \\
\hline Ethnic FE & Yes & Yes & Yes & Yes \\
\hline Main Controls & Yes & Yes & Yes & Yes \\
\hline First-stage F-statistic & 34.14 & 17.68 & 20.90 & 18.26 \\
\hline Adjusted- $R^{2}$ & 0.30 & 0.28 & 0.32 & 0.29 \\
\hline Observations & 14078 & 9646 & 4432 & 1507 \\
\hline
\end{tabular}

Notes: Heteroskedasticity robust standard error estimates clustered at the country-level are reported in parentheses; $* * *$ denotes statistical significance at the $1 \%$ level, ${ }^{* *}$ at the $5 \%$ level, and $*$ at the $10 \%$ level, all for two-sided hypothesis tests. Main Controls refer to the sets of Geographic and Climatic controls described in Table 1. 


\section{C.2.6 Robustness to Conflict Data Source \& Types - IV}

Table C.17: Historical Ethnic Borders and Conflict - PRIO (IV)

\begin{tabular}{|c|c|c|c|c|c|c|c|}
\hline & \multicolumn{7}{|c|}{ Conflict } \\
\hline & \multicolumn{4}{|c|}{ Prevalence } & \multicolumn{3}{|c|}{ Intensity } \\
\hline & \multicolumn{4}{|c|}{ Presence } & \multirow{2}{*}{$\frac{\text { Events }}{(5)}$} & \multirow{2}{*}{$\frac{\text { Years }}{(6)}$} & \multirow{2}{*}{$\frac{\text { Fatalities }}{(7)}$} \\
\hline & $(1)$ & $(2)$ & $(3)$ & $(4)$ & & & \\
\hline Presence of Ethnic Border & $\begin{array}{l}0.223^{* * *} \\
(0.061)\end{array}$ & $\begin{array}{l}0.169 * * * \\
(0.038)\end{array}$ & $\begin{array}{l}0.134^{* *} \\
(0.055)\end{array}$ & $\begin{array}{l}0.121^{* *} \\
(0.059)\end{array}$ & $\begin{array}{l}0.214^{* *} \\
(0.103)\end{array}$ & $\begin{array}{l}0.011^{* *} \\
(0.006)\end{array}$ & $\begin{array}{l}0.616^{* * *} \\
(0.213)\end{array}$ \\
\hline Country FE & No & Yes & Yes & Yes & Yes & Yes & Yes \\
\hline Ethnic FE & No & No & Yes & Yes & Yes & Yes & Yes \\
\hline Main Controls & No & No & No & Yes & Yes & Yes & Yes \\
\hline First-stage F-statistic & 319.16 & 207.65 & 35.03 & 34.14 & 34.14 & 34.14 & 34.14 \\
\hline Adjusted- $R^{2}$ & -0.04 & 0.15 & 0.35 & 0.36 & 0.42 & 0.39 & 0.38 \\
\hline Observations & 14078 & 14078 & 14078 & 14078 & 14078 & 14078 & 14078 \\
\hline
\end{tabular}

Notes: Heteroskedasticity robust standard error estimates clustered at the country-level are reported in parentheses; *** denotes statistical significance at the $1 \%$ level, ** at the $5 \%$ level, and * at the $10 \%$ level, all for two-sided hypothesis tests. Main Controls refer to the sets of Geographic and Climatic controls described in Table 1.

Table C.18: Historical Ethnic Borders and Conflict (IV) Effect on Type of Conflict (PRIO)

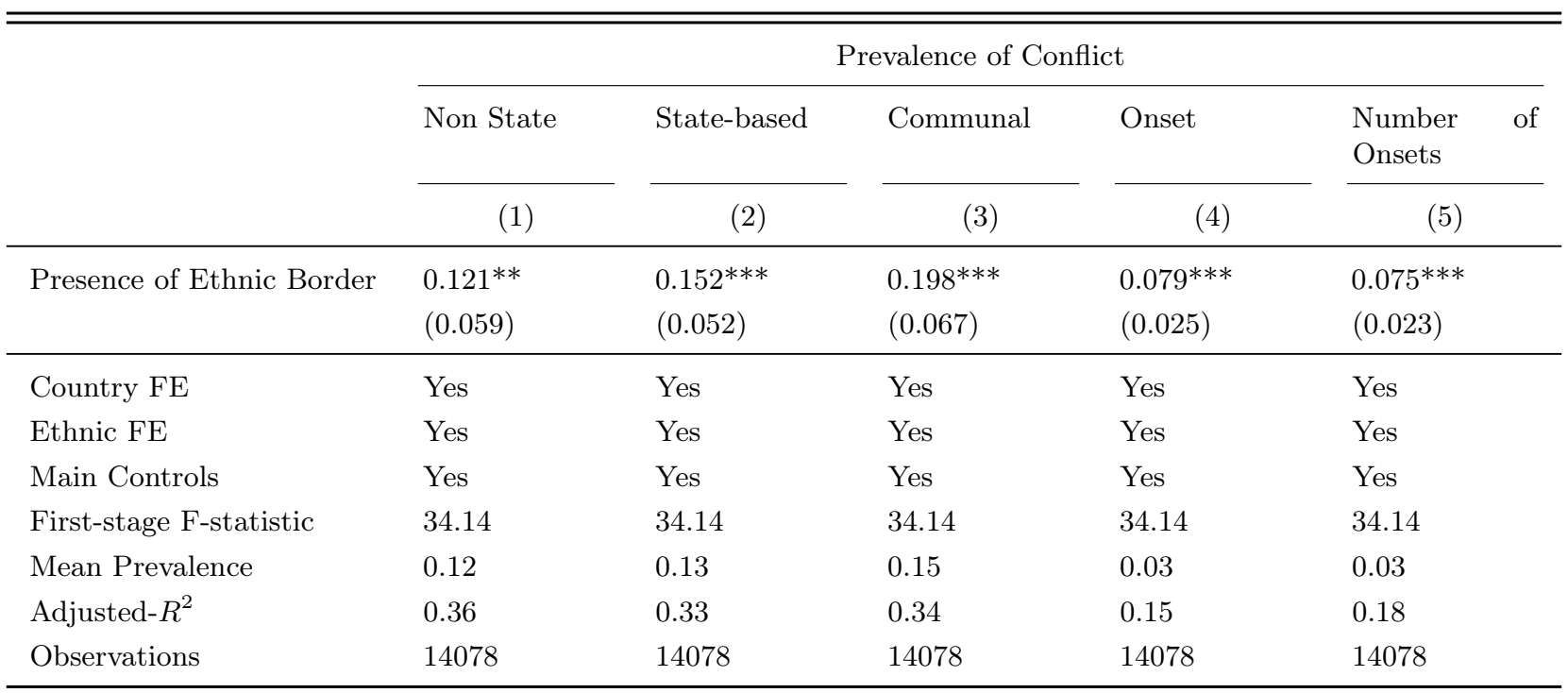

Notes: Heteroskedasticity robust standard error estimates clustered at the country-level are reported in parentheses; ${ }^{* * *}$ denotes statistical significance at the $1 \%$ level, ${ }^{* *}$ at the $5 \%$ level, and ${ }^{*}$ at the $10 \%$ level, all for two-sided hypothesis tests. Main Controls refer to the sets of Geographic and Climatic controls described in Table 1. 


\section{C.2.7 Robustness to Climate and Disease Environment - IV}

Table C.19: Historical Ethnic Borders and Conflict (IV)

Robustness to Disease and Climate

\begin{tabular}{|c|c|c|c|c|c|}
\hline & \multicolumn{5}{|c|}{ Prevalence of Conflict } \\
\hline & (1) & $(2)$ & (3) & (4) & (5) \\
\hline Presence of Ethnic Border & $\begin{array}{l}0.273^{* * *} \\
(0.066)\end{array}$ & $\begin{array}{l}0.270^{* * *} \\
(0.069)\end{array}$ & $\begin{array}{l}0.268^{* * *} \\
(0.071)\end{array}$ & $\begin{array}{l}0.288^{* * *} \\
(0.068)\end{array}$ & $\begin{array}{l}0.282^{* * *} \\
(0.074)\end{array}$ \\
\hline Malaria (mean) & & $\begin{array}{l}-0.002 \\
(0.018)\end{array}$ & & & $\begin{array}{l}0.000 \\
(0.017)\end{array}$ \\
\hline Malaria (std) & & $\begin{array}{l}0.003 \\
(0.003)\end{array}$ & & & $\begin{array}{l}0.002 \\
(0.003)\end{array}$ \\
\hline Tse-Tse (mean) & & & $\begin{array}{l}0.002 \\
(0.020)\end{array}$ & & $\begin{array}{l}0.001 \\
(0.021)\end{array}$ \\
\hline Tse-Tse (std) & & & $\begin{array}{l}0.009 \\
(0.008)\end{array}$ & & $\begin{array}{l}0.007 \\
(0.008)\end{array}$ \\
\hline Diurnal Temperature Range (degrees Celsius) (mean) & & & & $\begin{array}{l}0.023 \\
(0.018)\end{array}$ & $\begin{array}{l}0.023 \\
(0.018)\end{array}$ \\
\hline Vapour Pressure (hPa) (mean) & & & & $\begin{array}{l}0.007 \\
(0.030)\end{array}$ & $\begin{array}{l}0.006 \\
(0.031)\end{array}$ \\
\hline Cloud Cover ( & & & & $(0.032)$ & $(0.032)$ \\
\hline Wet Day Frequency (days) (mean) & & & & $\begin{array}{l}0.002 \\
(0.039)\end{array}$ & $\begin{array}{l}0.001 \\
(0.039)\end{array}$ \\
\hline Diurnal Temperature Range (degrees Celsius) (std) & & & & $\begin{array}{l}0.026^{* * *} \\
(0.007)\end{array}$ & $\begin{array}{l}0.027^{* * *} \\
(0.007)\end{array}$ \\
\hline Vapour Pressure (hPa) (std) & & & & $\begin{array}{l}0.044^{* * *} \\
(0.011)\end{array}$ & $\begin{array}{l}0.044^{* * *} \\
(0.012)\end{array}$ \\
\hline Cloud Cover ( & & & & $(0.007)$ & $(0.007)$ \\
\hline Wet Day Frequency (days) (std) & & & & $\begin{array}{l}0.026^{* *} \\
(0.011)\end{array}$ & $\begin{array}{l}0.025^{* *} \\
(0.010)\end{array}$ \\
\hline Country FE & Yes & Yes & Yes & Yes & Yes \\
\hline Ethnic FE & Yes & Yes & Yes & Yes & Yes \\
\hline Main Controls & Yes & Yes & Yes & Yes & Yes \\
\hline First-stage F-statistic & 34.14 & 36.16 & 31.85 & 34.59 & 33.81 \\
\hline Adjusted- $R^{2}$ & 0.30 & 0.30 & 0.30 & 0.30 & 0.30 \\
\hline Observations & 14078 & 14078 & 14078 & 14078 & 14078 \\
\hline
\end{tabular}

Notes: Heteroskedasticity robust standard error estimates clustered at the country-level are reported in parentheses; ${ }^{* * *}$ denotes statistical significance at the $1 \%$ level, $* *$ at the $5 \%$ level, and * at the $10 \%$ level, all for two-sided hypothesis tests. Main Controls refer to the sets of Geographic and Climatic controls described in Table 1. 


\section{C.2.8 Robustness to Geographical Isolation and Water Access - IV}

Table C.20: Historical Ethnic Borders and Conflict (IV) Robustness to Geographical Isolation and Access to Water

\begin{tabular}{|c|c|c|c|c|c|c|c|}
\hline & \multicolumn{7}{|c|}{ Prevalence of Conflict } \\
\hline & $(1)$ & $(2)$ & $(3)$ & $(4)$ & $(5)$ & $(6)$ & $(7)$ \\
\hline Presence of Ethnic Border & $\begin{array}{l}0.273^{* * *} \\
(0.066)\end{array}$ & $\begin{array}{l}0.272^{* * *} \\
(0.066)\end{array}$ & $\begin{array}{l}0.273^{* * *} \\
(0.066)\end{array}$ & $\begin{array}{l}0.272^{* * *} \\
(0.065)\end{array}$ & $\begin{array}{l}0.248^{* * *} \\
(0.078)\end{array}$ & $\begin{array}{l}0.273^{* * *} \\
(0.066)\end{array}$ & $\begin{array}{l}0.242^{* * *} \\
(0.077)\end{array}$ \\
\hline Country FE & Yes & Yes & Yes & Yes & Yes & Yes & Yes \\
\hline Ethnic FE & Yes & Yes & Yes & Yes & Yes & Yes & Yes \\
\hline Main Controls & Yes & Yes & Yes & Yes & Yes & Yes & Yes \\
\hline Additional Controls & None & Ruggedness & Mobility & River Length & Coast Length & Water Access & All \\
\hline First-stage F-statistic & 34.14 & 34.12 & 34.14 & 34.20 & 36.79 & 34.14 & 36.87 \\
\hline Adjusted- $R^{2}$ & 0.30 & 0.30 & 0.30 & 0.31 & 0.31 & 0.30 & 0.31 \\
\hline Observations & 14078 & 14078 & 14078 & 14078 & 14078 & 14078 & 14078 \\
\hline
\end{tabular}




\section{C.2.9 Robustness to Rivers, Coasts and Other Borders - IV}

Table C.21: Historical Ethnic Borders and Conflict (IV) Robustness to Rivers, Coasts and Other Types of Borders

\begin{tabular}{|c|c|c|c|c|c|c|c|}
\hline & \multicolumn{7}{|c|}{ Prevalence of Conflict } \\
\hline & (1) & $(2)$ & $(3)$ & $(4)$ & $(5)$ & $(6)$ & $(7)$ \\
\hline Presence of Ethnic Border & $\begin{array}{l}0.273^{* * *} \\
(0.066)\end{array}$ & $\begin{array}{l}0.279 * * * \\
(0.065)\end{array}$ & $\begin{array}{l}0.396^{* * *} \\
(0.112)\end{array}$ & $\begin{array}{l}0.250^{* * *} \\
(0.072)\end{array}$ & $\begin{array}{l}0.280 * * * \\
(0.062)\end{array}$ & $\begin{array}{l}0.283^{* * *} \\
(0.065)\end{array}$ & $\begin{array}{l}0.295^{* * *} \\
(0.102)\end{array}$ \\
\hline Presence of River & & $\begin{array}{l}0.060^{* * *} \\
(0.017)\end{array}$ & & & & & $\begin{array}{l}0.064^{* * *} \\
(0.016)\end{array}$ \\
\hline Presence of Coast & & & $\begin{array}{c}-0.156^{*} \\
(0.081)\end{array}$ & & & & $\begin{array}{l}-0.043 \\
(0.071)\end{array}$ \\
\hline Presence of Ecological Border & & & & $\begin{array}{l}0.027^{*} \\
(0.016)\end{array}$ & & & $\begin{array}{l}0.033^{* *} \\
(0.014)\end{array}$ \\
\hline Presence of Country Border & & & & & $\begin{array}{l}-0.088^{* * *} \\
(0.016)\end{array}$ & & $\begin{array}{l}-0.074^{* * *} \\
(0.015)\end{array}$ \\
\hline Presence of Administrative Border & & & & & & $\begin{array}{l}-0.052^{* * *} \\
(0.010)\end{array}$ & $\begin{array}{l}-0.022^{* *} \\
(0.010)\end{array}$ \\
\hline Country FE & Yes & Yes & Yes & Yes & Yes & Yes & Yes \\
\hline Ethnic FE & Yes & Yes & Yes & Yes & Yes & Yes & Yes \\
\hline Main Controls & Yes & Yes & Yes & Yes & Yes & Yes & Yes \\
\hline First-stage F-statistic & 34.14 & 34.17 & 34.40 & 35.66 & 41.28 & 36.67 & 34.70 \\
\hline Adjusted- $R^{2}$ & 0.30 & 0.30 & 0.28 & 0.31 & 0.31 & 0.30 & 0.31 \\
\hline Observations & 14078 & 14078 & 14078 & 14078 & 14078 & 14078 & 14078 \\
\hline
\end{tabular}

Notes: Heteroskedasticity robust standard error estimates clustered at the country-level are reported in parentheses; $* * *$ denotes statistical significance at the $1 \%$ level, $* *$ at the $5 \%$ level, and $*$ at the $10 \%$ level, all for two-sided hypothesis tests. Main Controls refer to the sets of Geographic and Climatic controls described in Table 1. 


\section{C.2.10 Robustness to Other Sources of Conflict - IV}

Table C.22: Historical Ethnic Borders and Conflict (IV)

Robustness to Other Sources of Conflict

\begin{tabular}{|c|c|c|c|c|c|c|c|}
\hline & \multicolumn{7}{|c|}{ Prevalence of Conflict } \\
\hline & $(1)$ & $(2)$ & (3) & $(4)$ & $(5)$ & (6) & $(7)$ \\
\hline Presence of Ethnic Border & $\begin{array}{l}0.273^{* * *} \\
(0.066)\end{array}$ & $\begin{array}{l}0.266^{* * *} \\
(0.066)\end{array}$ & $\begin{array}{l}0.263^{* * *} \\
(0.065)\end{array}$ & $\begin{array}{l}0.272^{* * *} \\
(0.066)\end{array}$ & $\begin{array}{l}0.264^{* * *} \\
(0.064)\end{array}$ & $\begin{array}{l}0.216^{* * *} \\
(0.061)\end{array}$ & $\begin{array}{l}0.206^{* * *} \\
(0.060)\end{array}$ \\
\hline Presence of Diamond & & $\begin{array}{l}0.100^{* * *} \\
(0.022)\end{array}$ & & & & & $\begin{array}{l}0.041^{*} \\
(0.021)\end{array}$ \\
\hline Presence of Mineral & & & $\begin{array}{l}0.145^{* * *} \\
(0.018)\end{array}$ & & & & $\begin{array}{l}0.094^{* * *} \\
(0.015)\end{array}$ \\
\hline Presence of Oil & & & & $\begin{array}{l}0.007 \\
(0.016)\end{array}$ & & & $\begin{array}{l}-0.002 \\
(0.014)\end{array}$ \\
\hline Presence of Capitals & & & & & $\begin{array}{l}0.491^{* * *} \\
(0.044)\end{array}$ & & $\begin{array}{l}0.171^{* * *} \\
(0.044)\end{array}$ \\
\hline Presence of Populated Place & & & & & & $\begin{array}{l}0.397^{* * *} \\
(0.024)\end{array}$ & $\begin{array}{l}0.381^{* * *} \\
(0.024)\end{array}$ \\
\hline Country FE & Yes & Yes & Yes & Yes & Yes & Yes & Yes \\
\hline Ethnic FE & Yes & Yes & Yes & Yes & Yes & Yes & Yes \\
\hline Main Controls & Yes & Yes & Yes & Yes & Yes & Yes & Yes \\
\hline First-stage F-statistic & 34.14 & 34.33 & 34.05 & 34.52 & 33.94 & 34.57 & 34.87 \\
\hline Adjusted- $R^{2}$ & 0.30 & 0.31 & 0.31 & 0.30 & 0.31 & 0.38 & 0.38 \\
\hline Observations & 14078 & 14078 & 14078 & 14078 & 14078 & 14078 & 14078 \\
\hline
\end{tabular}

Notes: Heteroskedasticity robust standard error estimates clustered at the country-level are reported in parentheses; *** denotes statistical significance at the $1 \%$ level, ** at the $5 \%$ level, and * at the $10 \%$ level, all for two-sided hypothesis tests. Main Controls refer to the sets of Geographic and Climatic controls described in Table 1. 
Table C.23: Historical Ethnic Borders and Conflict (IV)

Robustness to Distance to Other Sources of Conflict

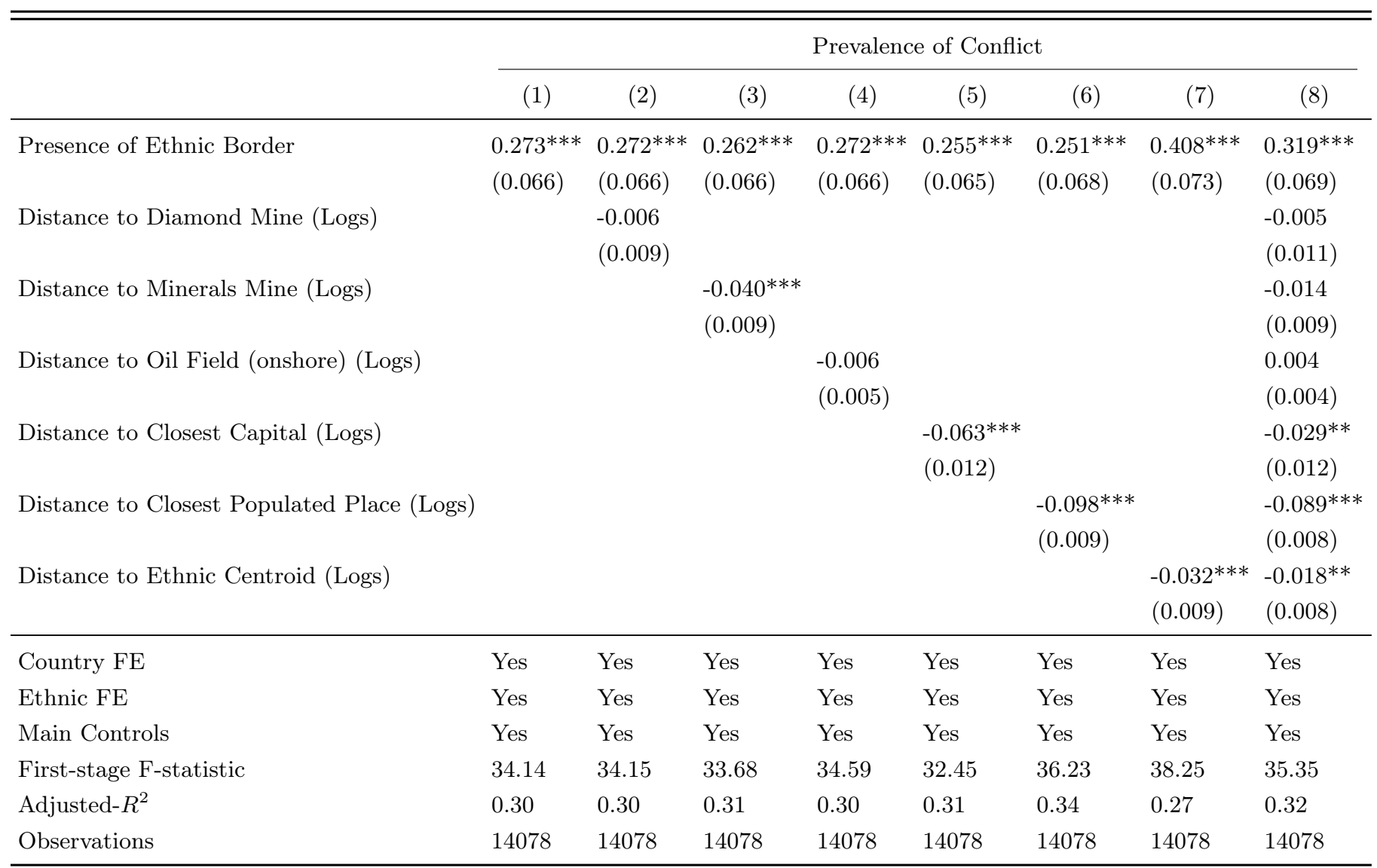

Notes: Heteroskedasticity robust standard error estimates clustered at the country-level are reported in parentheses; $* * *$ denotes statistical significance at the $1 \%$ level, ${ }^{* *}$ at the $5 \%$ level, and ${ }^{*}$ at the $10 \%$ level, all for two-sided hypothesis tests. Main Controls refer to the sets of Geographic and Climatic controls described in Table 1. 


\section{C.2.11 Robustness to Diversity - IV}

Table C.24: Historical Ethnic Borders and Conflict (IV)

Robustness to Intra- and Inter-Ethnic Diversity

\begin{tabular}{|c|c|c|c|c|c|c|}
\hline & \multicolumn{6}{|c|}{ Prevalence of Conflict } \\
\hline & $(1)$ & $(2)$ & $(3)$ & $(4)$ & $(5)$ & $(6)$ \\
\hline Presence of Ethnic Border & $\begin{array}{l}0.273^{* * *} \\
(0.066)\end{array}$ & $\begin{array}{l}0.273^{* * *} \\
(0.066)\end{array}$ & $\begin{array}{l}0.259^{* * *} \\
(0.066)\end{array}$ & $\begin{array}{l}0.287^{* * *} \\
(0.067)\end{array}$ & $\begin{array}{l}0.263^{* * *} \\
(0.065)\end{array}$ & $\begin{array}{l}0.263^{* * *} \\
(0.065)\end{array}$ \\
\hline Number of Languages & & $\begin{array}{l}0.007 \\
(0.005)\end{array}$ & & & & $\begin{array}{l}-0.004 \\
(0.004)\end{array}$ \\
\hline Ethnolinguistic Fractionalization & & & $\begin{array}{l}0.029^{* * *} \\
(0.006)\end{array}$ & & & $\begin{array}{l}0.031^{* * *} \\
(0.006)\end{array}$ \\
\hline Agricultural Suitability (Climatic) (mean) & & & & $\begin{array}{l}0.089 * * * \\
(0.017)\end{array}$ & & $\begin{array}{l}0.085^{* * *} \\
(0.017)\end{array}$ \\
\hline Agricultural Suitability (Climatic) (std) & & & & $\begin{array}{l}0.014^{* *} \\
(0.006)\end{array}$ & & $\begin{array}{l}0.011^{*} \\
(0.006)\end{array}$ \\
\hline Ecological Diversity & & & & & $\begin{array}{l}0.019^{* * *} \\
(0.005)\end{array}$ & $\begin{array}{l}0.016^{* * *} \\
(0.005)\end{array}$ \\
\hline Country FE & Yes & Yes & Yes & Yes & Yes & Yes \\
\hline Ethnic FE & Yes & Yes & Yes & Yes & Yes & Yes \\
\hline Main Controls & Yes & Yes & Yes & Yes & Yes & Yes \\
\hline First-stage F-statistic & 34.15 & 34.12 & 33.69 & 34.69 & 33.18 & 33.38 \\
\hline Adjusted- $R^{2}$ & 0.30 & 0.30 & 0.31 & 0.30 & 0.31 & 0.31 \\
\hline Observations & 14077 & 14077 & 14077 & 14077 & 14077 & 14077 \\
\hline
\end{tabular}

Notes: Heteroskedasticity robust standard error estimates clustered at the country-level are reported in parentheses; *** denotes statistical significance at the $1 \%$ level, ** at the $5 \%$ level, and * at the $10 \%$ level, all for two-sided hypothesis tests. Main Controls refer to the sets of Geographic and Climatic controls described in Table 1. 


\section{C.2.12 Historical Ethnic Borders and Historical Conflict- IV}

Table C.25: Historical Ethnic Borders and Conflict (IV)

Robustness to Historical Conflict

\begin{tabular}{|c|c|c|c|c|c|c|}
\hline & \multicolumn{6}{|c|}{ Prevalence of Conflict } \\
\hline & \multicolumn{3}{|c|}{ Historical Conflict } & \multicolumn{3}{|c|}{ Contemporary Conflict } \\
\hline & All & Both AFR & Non-AFR & All & Both AFR & Non-AFR \\
\hline & (1) & $(2)$ & $(3)$ & $(4)$ & $(5)$ & (6) \\
\hline \multirow[t]{2}{*}{ Presence of Ethnic Border } & 0.001 & -0.016 & 0.016 & $0.272^{* * *}$ & $0.276^{* * *}$ & $0.269^{* * *}$ \\
\hline & $(0.016)$ & $(0.010)$ & $(0.014)$ & $(0.066)$ & $(0.066)$ & $(0.065)$ \\
\hline \multirow[t]{2}{*}{ Presence of Historical Conflicts } & & & & $0.239 * * *$ & $0.222^{* * *}$ & $0.234^{* * *}$ \\
\hline & & & & $(0.033)$ & $(0.041)$ & $(0.036)$ \\
\hline Country FE & Yes & Yes & Yes & Yes & Yes & Yes \\
\hline Ethnic FE & Yes & Yes & Yes & Yes & Yes & Yes \\
\hline Main Controls & Yes & Yes & Yes & Yes & Yes & Yes \\
\hline First-stage F-statistic & 34.14 & 34.14 & 34.14 & 34.09 & 34.16 & 34.10 \\
\hline Adjusted- $R^{2}$ & 0.06 & 0.06 & 0.04 & 0.31 & 0.30 & 0.31 \\
\hline Observations & 14078 & 14078 & 14078 & 14078 & 14078 & 14078 \\
\hline
\end{tabular}

Notes: Heteroskedasticity robust standard error estimates clustered at the country-level are reported in parentheses; $* * *$ denotes statistical significance at the $1 \%$ level, $* *$ at the $5 \%$ level, and * at the $10 \%$ level, all for two-sided hypothesis tests. Main Controls refer to the sets of Geographic and Climatic controls described in Table 1.

Table C.26: Historical Ethnic Borders and Historical Conflict

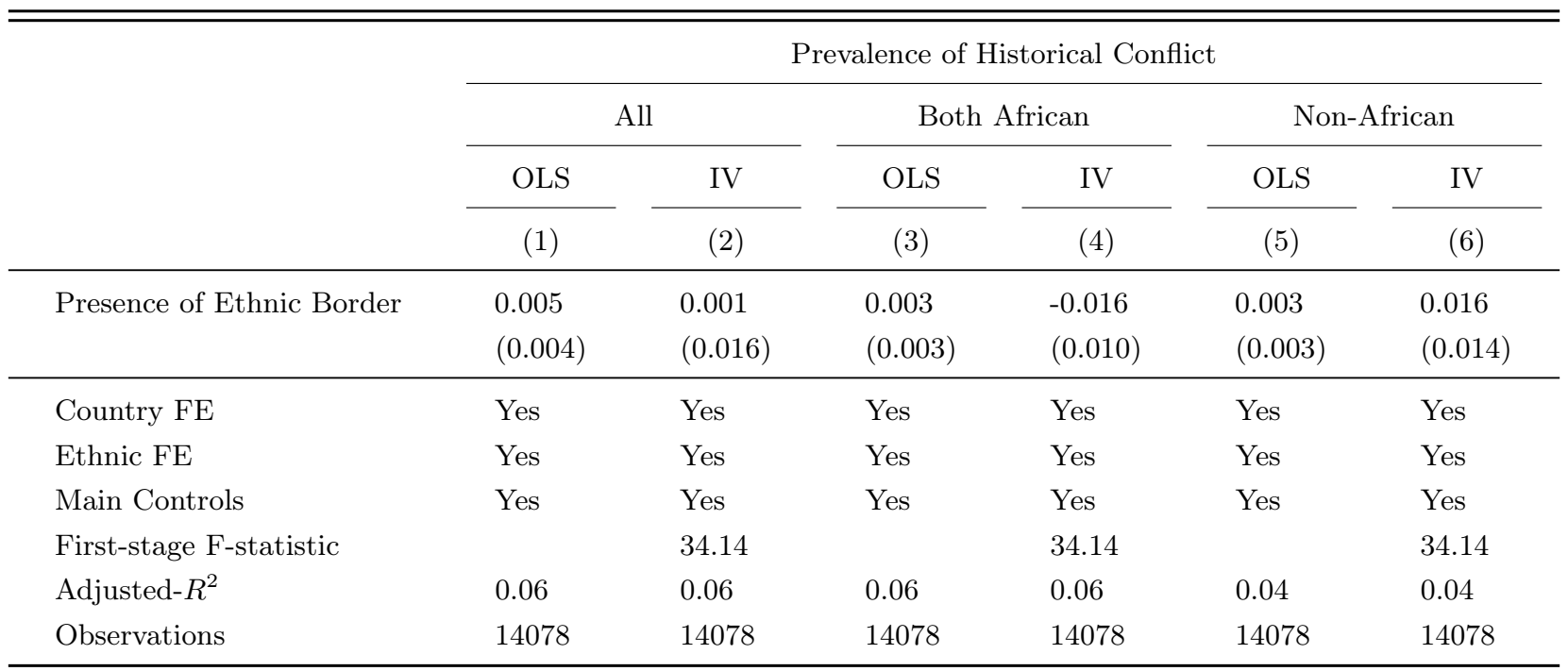

Notes: Heteroskedasticity robust standard error estimates clustered at the country-level are reported in parentheses; *** denotes statistical significance at the $1 \%$ level, ${ }^{* *}$ at the $5 \%$ level, and * at the $10 \%$ level, all for two-sided hypothesis tests. Main Controls refer to the sets of Geographic and Climatic controls described in Table 1. 
Table C.27: Historical Ethnic Borders and Land Ownership in Africa (IV)

\begin{tabular}{|c|c|c|c|c|c|c|c|c|}
\hline & \multicolumn{8}{|c|}{ Land Ownership } \\
\hline & \multicolumn{4}{|c|}{ Full Sample } & \multicolumn{4}{|c|}{ Self-Reported Ethnicity } \\
\hline & All & Rural & $\begin{array}{c}\text { Rural } \\
\text { Migrant }\end{array}$ & $\begin{array}{c}\text { Rural- } \\
\text { Rural } \\
\text { Migrant }\end{array}$ & All & Rural & $\begin{array}{l}\text { Rural } \\
\text { Migrant }\end{array}$ & $\begin{array}{c}\text { Rural- } \\
\text { Rural } \\
\text { Migrant }\end{array}$ \\
\hline & (1) & (2) & (3) & (4) & (5) & (6) & (7) & (8) \\
\hline Log[Distance to Ethnic Border] & $\begin{array}{l}0.018^{* * *} \\
(0.007)\end{array}$ & $\begin{array}{l}0.026^{* * *} \\
(0.008)\end{array}$ & $\begin{array}{l}0.041^{* *} \\
(0.021)\end{array}$ & $\begin{array}{l}0.046 \\
(0.028)\end{array}$ & $\begin{array}{l}0.033^{* * *} \\
(0.009)\end{array}$ & $\begin{array}{l}0.040^{* * *} \\
(0.013)\end{array}$ & $\begin{array}{l}0.077^{*} \\
(0.043)\end{array}$ & $\begin{array}{l}0.095^{* *} \\
(0.048)\end{array}$ \\
\hline Country FE & Yes & Yes & Yes & Yes & Yes & Yes & Yes & Yes \\
\hline Wave FE & Yes & Yes & Yes & Yes & Yes & Yes & Yes & Yes \\
\hline Ethnic Homeland FE & Yes & Yes & Yes & Yes & Yes & Yes & Yes & Yes \\
\hline Geographical Controls & Yes & Yes & Yes & Yes & Yes & Yes & Yes & Yes \\
\hline Individual Controls & Yes & Yes & Yes & Yes & Yes & Yes & Yes & Yes \\
\hline Self-Reported Ethnicity FE & No & No & No & No & Yes & Yes & Yes & Yes \\
\hline Mean Prevalence & 0.37 & 0.44 & 0.49 & 0.49 & 0.37 & 0.44 & 0.49 & 0.51 \\
\hline First-stage F-statistic & 123.10 & 106.72 & 49.65 & 34.43 & 55.65 & 47.30 & 17.22 & 16.04 \\
\hline Adjusted- $R^{2}$ & 0.13 & 0.15 & 0.08 & 0.05 & 0.12 & 0.12 & 0.04 & 0.01 \\
\hline Observations & 874415 & 605630 & 116795 & 69092 & 600668 & 412783 & 76472 & 50592 \\
\hline
\end{tabular}

Notes: Heteroskedasticity robust standard error estimates clustered at the ethnic homeland-level are reported in parentheses; *** denotes statistical significance at the $1 \%$ level, ** at the $5 \%$ level, and * at the $10 \%$ level, all for two-sided hypothesis tests. Main Controls refer to the sets of Geographic and Climatic controls described in Table 1 (computed for a $25 \mathrm{~km}$ buffer around the respondent location).

\section{C.2.13 Robustness to Centroid Selection and Voronoi Construction - IV}

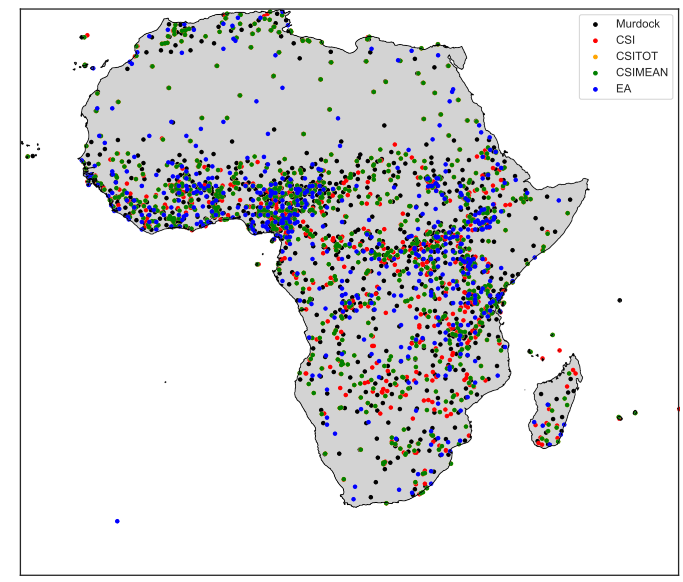

Figure C.1: Location of Centroids by Source and Method 


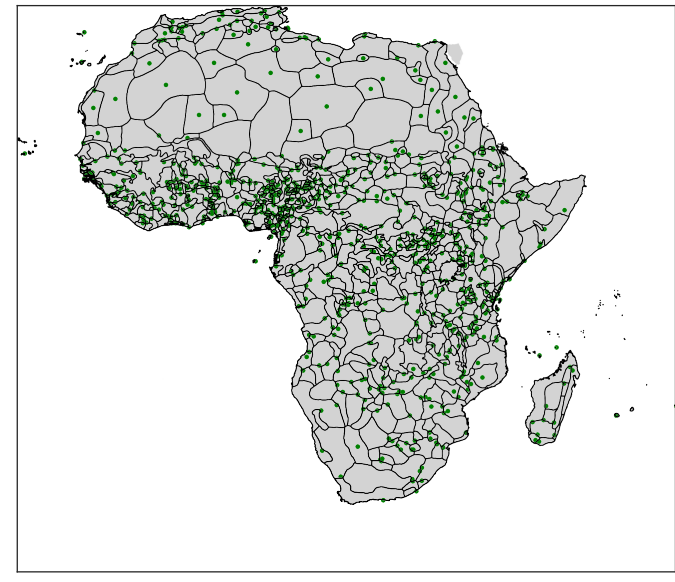

(a) Historical Borders \& CSI Centroids of Ethnic Homelands

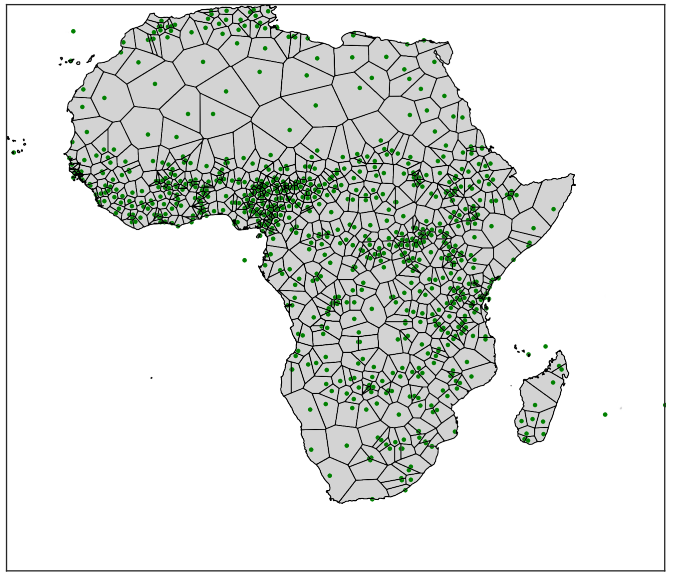

(b) Potential Borders \& CSI Centroids of Ethnic Homelands

Figure C.2: Historical Ethnic Borders, CSI Centroids and CSI Potential (Voronoi) Borders in Africa

Table C.28: Historical Ethnic Borders and Conflict (IV) Robustness to Centroid Location (CSI)

\begin{tabular}{|c|c|c|c|c|c|c|c|}
\hline & \multicolumn{7}{|c|}{ Conflict } \\
\hline & \multirow{2}{*}{\multicolumn{2}{|c|}{$\begin{array}{c}\text { Prevalence } \\
\text { Presence }\end{array}$}} & \multicolumn{3}{|c|}{ Intensity } & \multicolumn{2}{|r|}{ Onset } \\
\hline & & & \multirow{2}{*}{$\frac{\text { Events }}{(3)}$} & \multirow{2}{*}{$\frac{\text { Years }}{(4)}$} & \multirow{2}{*}{$\frac{\text { Fatalities }}{(5)}$} & \multirow{2}{*}{$\frac{\text { Onset }}{(6)}$} & \multirow{2}{*}{$\frac{\text { Number of onsets }}{(7)}$} \\
\hline & $(1)$ & $(2)$ & & & & & \\
\hline Presence of Ethnic Border & $\begin{array}{l}0.389 * * * \\
(0.104)\end{array}$ & $\begin{array}{l}0.422^{* * *} \\
(0.123)\end{array}$ & $\begin{array}{l}0.904^{* * *} \\
(0.242)\end{array}$ & $\begin{array}{l}0.095^{* * *} \\
(0.027)\end{array}$ & $\begin{array}{l}0.661^{* * *} \\
(0.216)\end{array}$ & $\begin{array}{l}0.090 * * \\
(0.038)\end{array}$ & $\begin{array}{l}0.088^{* *} \\
(0.035)\end{array}$ \\
\hline Country FE & Yes & Yes & Yes & Yes & Yes & Yes & Yes \\
\hline Ethnic FE & Yes & Yes & Yes & Yes & Yes & Yes & Yes \\
\hline Main Controls & No & Yes & Yes & Yes & Yes & Yes & Yes \\
\hline First-stage F-statistic & 23.30 & 20.62 & 20.62 & 20.62 & 20.62 & 20.62 & 20.62 \\
\hline Mean Prevalence & 0.22 & 0.22 & 0.36 & 0.03 & 0.32 & 0.03 & 0.03 \\
\hline Adjusted- $R^{2}$ & 0.27 & 0.26 & 0.31 & 0.30 & 0.31 & 0.15 & 0.18 \\
\hline Observations & 14078 & 14078 & 14078 & 14078 & 14078 & 14078 & 14078 \\
\hline
\end{tabular}

Notes: Heteroskedasticity robust standard error estimates clustered at the country-level are reported in parentheses; $* * *$ denotes statistical significance at the $1 \%$ level, $* *$ at the $5 \%$ level, and * at the $10 \%$ level, all for two-sided hypothesis tests. Main Controls refer to the sets of Geographic and Climatic controls described in Table 1. 


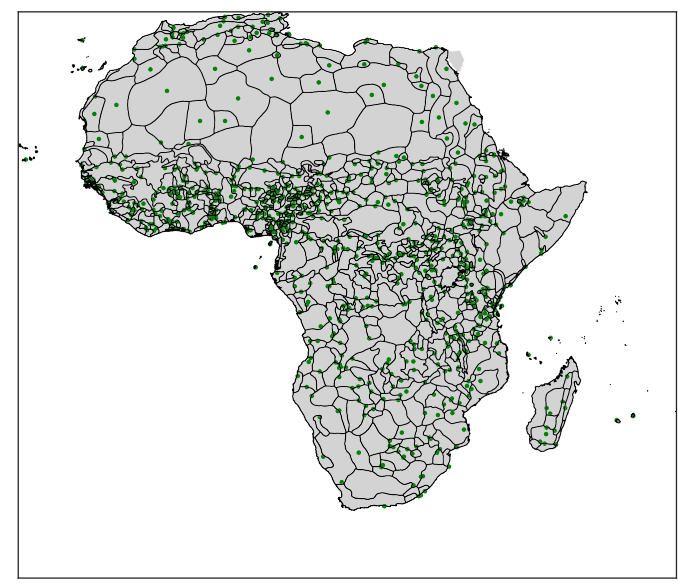

(a) Historical Borders \& CSIMEAN Centroids of Ethnic Homelands

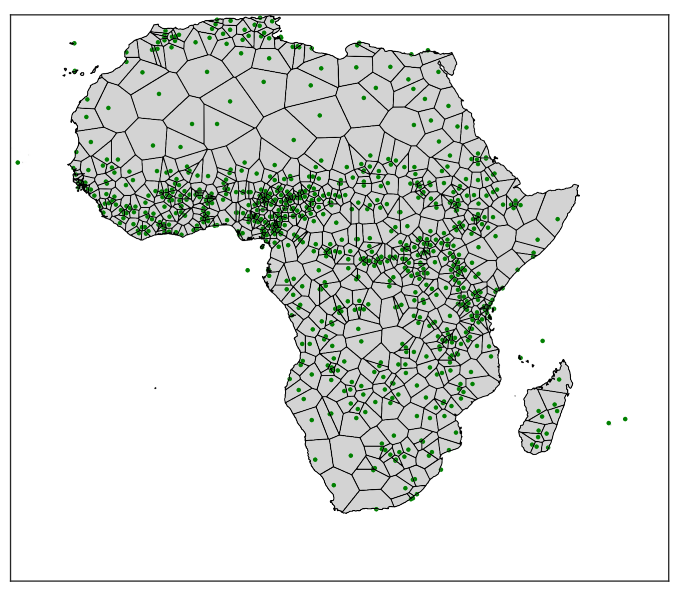

(b) Potential Borders \& CSIMEAN Centroids of Ethnic Homelands

Figure C.3: Historical Ethnic Borders, CSIMEAN Centroids and CSIMEAN Potential (Voronoi) Borders in Africa

Table C.29: Historical Ethnic Borders and Conflict (IV) Robustness to Centroid Location (CSIMEAN)

\begin{tabular}{|c|c|c|c|c|c|c|c|}
\hline & \multicolumn{7}{|c|}{ Conflict } \\
\hline & \multirow{2}{*}{\multicolumn{2}{|c|}{$\begin{array}{c}\text { Prevalence } \\
\text { Presence }\end{array}$}} & \multicolumn{3}{|c|}{ Intensity } & \multicolumn{2}{|r|}{ Onset } \\
\hline & & & \multirow{2}{*}{$\frac{\text { Events }}{(3)}$} & \multirow{2}{*}{$\frac{\text { Years }}{(4)}$} & \multirow{2}{*}{$\frac{\text { Fatalities }}{(5)}$} & \multirow{2}{*}{$\frac{\text { Onset }}{(6)}$} & \multirow{2}{*}{$\frac{\text { Number of onsets }}{(7)}$} \\
\hline & $(1)$ & $(2)$ & & & & & \\
\hline Presence of Ethnic Border & $\begin{array}{l}0.307^{* * *} \\
(0.090) \\
\end{array}$ & $\begin{array}{l}0.328^{* * *} \\
(0.105) \\
\end{array}$ & $\begin{array}{l}0.795^{* * *} \\
(0.221) \\
\end{array}$ & $\begin{array}{l}0.075^{* * *} \\
(0.022) \\
\end{array}$ & $\begin{array}{l}0.689^{* * *} \\
(0.226) \\
\end{array}$ & $\begin{array}{l}0.085^{* *} \\
(0.040) \\
\end{array}$ & $\begin{array}{l}0.098^{* * *} \\
(0.037)\end{array}$ \\
\hline Country FE & Yes & Yes & Yes & Yes & Yes & Yes & Yes \\
\hline Ethnic FE & Yes & Yes & Yes & Yes & Yes & Yes & Yes \\
\hline Main Controls & No & Yes & Yes & Yes & Yes & Yes & Yes \\
\hline First-stage F-statistic & 24.95 & 23.33 & 23.33 & 23.33 & 23.33 & 23.33 & 23.33 \\
\hline Mean Prevalence & 0.22 & 0.22 & 0.36 & 0.03 & 0.32 & 0.03 & 0.03 \\
\hline Adjusted- $R^{2}$ & 0.29 & 0.29 & 0.32 & 0.32 & 0.31 & 0.15 & 0.17 \\
\hline Observations & 14078 & 14078 & 14078 & 14078 & 14078 & 14078 & 14078 \\
\hline
\end{tabular}

Notes: Heteroskedasticity robust standard error estimates clustered at the country-level are reported in parentheses; *** denotes statistical significance at the $1 \%$ level, ** at the $5 \%$ level, and * at the $10 \%$ level, all for two-sided hypothesis tests. Main Controls refer to the sets of Geographic and Climatic controls described in Table 1. 


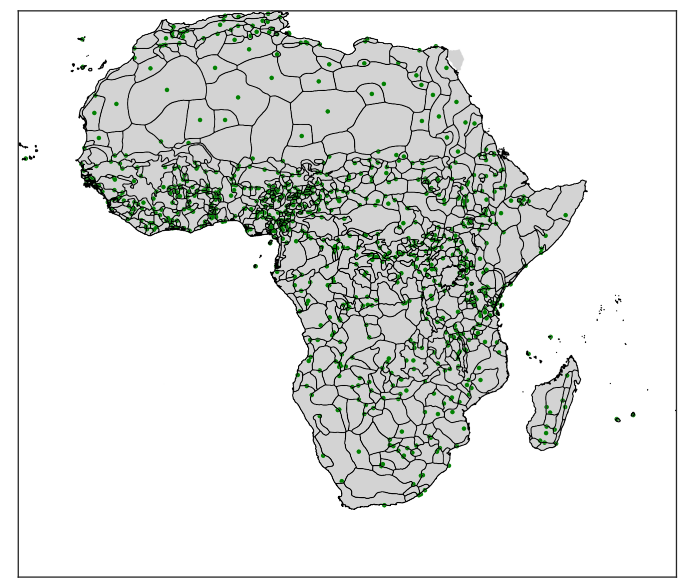

(a) Historical Borders \& CSITOT Centroids of Ethnic Homelands

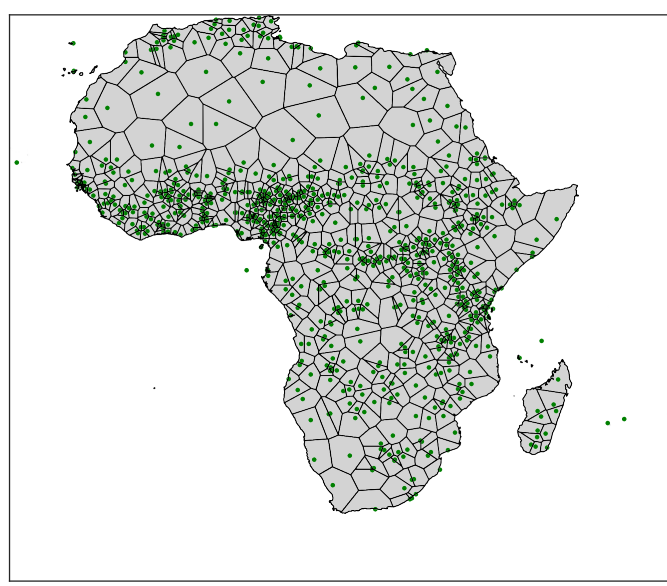

(b) Potential Borders \& CSITOT Centroids of Ethnic Homelands

Figure C.4: Historical Ethnic Borders, CSITOT Centroids and CSITOT Potential (Voronoi) Borders in Africa

Table C.30: Historical Ethnic Borders and Conflict (IV) Robustness to Centroid Location (CSITOT)

\begin{tabular}{|c|c|c|c|c|c|c|c|}
\hline & \multicolumn{7}{|c|}{ Conflict } \\
\hline & \multirow{2}{*}{\multicolumn{2}{|c|}{$\begin{array}{c}\text { Prevalence } \\
\text { Presence }\end{array}$}} & \multicolumn{3}{|c|}{ Intensity } & \multicolumn{2}{|r|}{ Onset } \\
\hline & & & \multirow{2}{*}{$\frac{\text { Events }}{(3)}$} & \multirow{2}{*}{$\frac{\text { Years }}{(4)}$} & \multirow{2}{*}{$\frac{\text { Fatalities }}{(5)}$} & \multirow{2}{*}{$\frac{\text { Onset }}{(6)}$} & \multirow{2}{*}{$\frac{\text { Number of onsets }}{(7)}$} \\
\hline & $(1)$ & $(2)$ & & & & & \\
\hline Presence of Ethnic Border & $\begin{array}{l}0.307 * * * \\
(0.090)\end{array}$ & $\begin{array}{l}0.328^{* * *} \\
(0.105)\end{array}$ & $\begin{array}{l}0.795^{* * *} \\
(0.221)\end{array}$ & $\begin{array}{l}0.075^{* * *} \\
(0.022)\end{array}$ & $\begin{array}{l}0.689^{* * *} \\
(0.226)\end{array}$ & $\begin{array}{l}0.085^{* *} \\
(0.040)\end{array}$ & $\begin{array}{l}0.098^{* * *} \\
(0.037)\end{array}$ \\
\hline Country FE & Yes & Yes & Yes & Yes & Yes & Yes & Yes \\
\hline Ethnic FE & Yes & Yes & Yes & Yes & Yes & Yes & Yes \\
\hline Main Controls & No & Yes & Yes & Yes & Yes & Yes & Yes \\
\hline First-stage F-statistic & 24.95 & 23.33 & 23.33 & 23.33 & 23.33 & 23.33 & 23.33 \\
\hline Mean Prevalence & 0.22 & 0.22 & 0.36 & 0.03 & 0.32 & 0.03 & 0.03 \\
\hline Adjusted- $R^{2}$ & 0.29 & 0.29 & 0.32 & 0.32 & 0.31 & 0.15 & 0.17 \\
\hline Observations & 14078 & 14078 & 14078 & 14078 & 14078 & 14078 & 14078 \\
\hline
\end{tabular}

Notes: Heteroskedasticity robust standard error estimates clustered at the country-level are reported in parentheses; ${ }^{* * *}$ denotes statistical significance at the $1 \%$ level, ** at the $5 \%$ level, and * at the $10 \%$ level, all for two-sided hypothesis tests. Main Controls refer to the sets of Geographic and Climatic controls described in Table 1. 


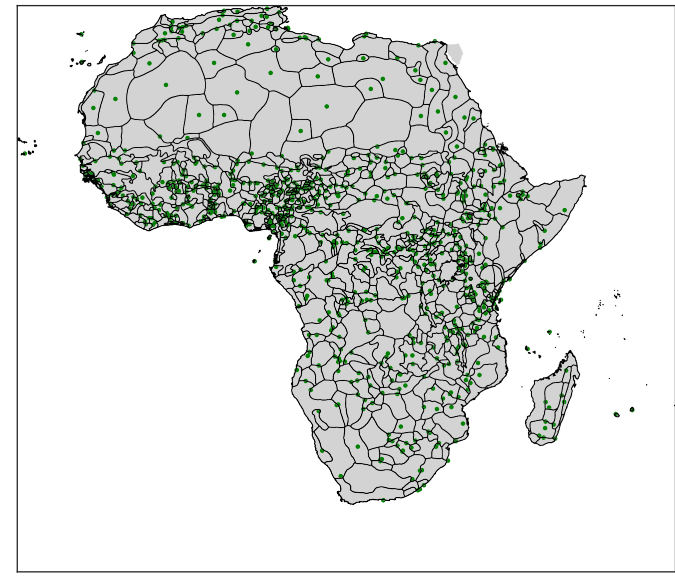

(a) Historical Borders \& EA Centroids of Ethnic Homelands

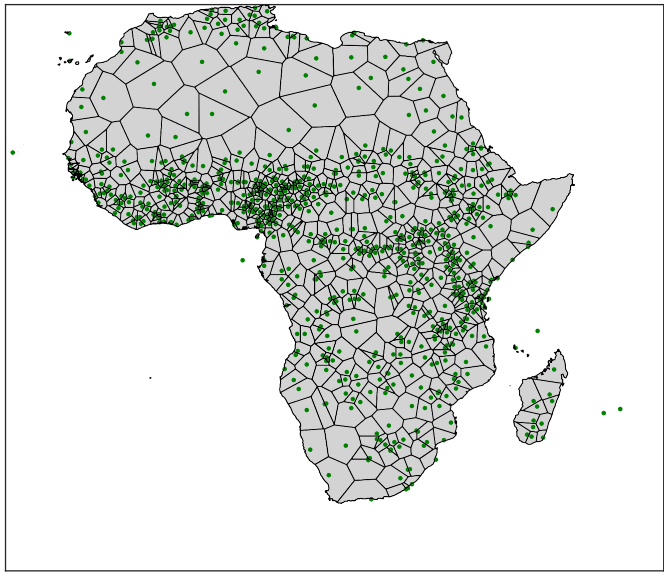

(b) Potential Borders \& EA Centroids of Ethnic Homelands

Figure C.5: Historical Ethnic Borders, EA Centroids and EA Potential (Voronoi) Borders in Africa

Table C.31: Historical Ethnic Borders and Conflict (IV) Robustness to Centroid Location (EA)

\begin{tabular}{|c|c|c|c|c|c|c|c|}
\hline & \multicolumn{7}{|c|}{ Conflict } \\
\hline & \multirow{2}{*}{\multicolumn{2}{|c|}{$\begin{array}{c}\text { Prevalence } \\
\text { Presence }\end{array}$}} & \multicolumn{3}{|c|}{ Intensity } & \multicolumn{2}{|r|}{ Onset } \\
\hline & & & \multirow{2}{*}{$\frac{\text { Events }}{(3)}$} & \multirow{2}{*}{$\frac{\text { Years }}{(4)}$} & \multirow{2}{*}{$\frac{\text { Fatalities }}{(5)}$} & \multirow{2}{*}{$\frac{\text { Onset }}{(6)}$} & \multirow{2}{*}{$\frac{\text { Number of onsets }}{(7)}$} \\
\hline & (1) & $(2)$ & & & & & \\
\hline Presence of Ethnic Border & $\begin{array}{l}0.407^{* * *} \\
(0.096)\end{array}$ & $\begin{array}{l}0.433^{* * *} \\
(0.103)\end{array}$ & $\begin{array}{l}0.787^{* * *} \\
(0.201)\end{array}$ & $\begin{array}{l}0.062^{* * *} \\
(0.019)\end{array}$ & $\begin{array}{l}0.581^{* * *} \\
(0.204)\end{array}$ & $\begin{array}{l}0.031 \\
(0.037)\end{array}$ & $\begin{array}{l}0.040 \\
(0.032)\end{array}$ \\
\hline Country FE & Yes & Yes & Yes & Yes & Yes & Yes & Yes \\
\hline Ethnic FE & Yes & Yes & Yes & Yes & Yes & Yes & Yes \\
\hline Main Controls & No & Yes & Yes & Yes & Yes & Yes & Yes \\
\hline First-stage F-statistic & 29.31 & 28.84 & 28.84 & 28.84 & 28.84 & 28.84 & 28.84 \\
\hline Mean Prevalence & 0.22 & 0.22 & 0.36 & 0.03 & 0.32 & 0.03 & 0.03 \\
\hline Adjusted- $R^{2}$ & 0.26 & 0.26 & 0.32 & 0.34 & 0.32 & 0.16 & 0.19 \\
\hline Observations & 14078 & 14078 & 14078 & 14078 & 14078 & 14078 & 14078 \\
\hline
\end{tabular}

Notes: Heteroskedasticity robust standard error estimates clustered at the country-level are reported in parentheses; $* * *$ denotes statistical significance at the $1 \%$ level, ** at the $5 \%$ level, and * at the $10 \%$ level, all for two-sided hypothesis tests. Main Controls refer to the sets of Geographic and Climatic controls described in Table 1. 


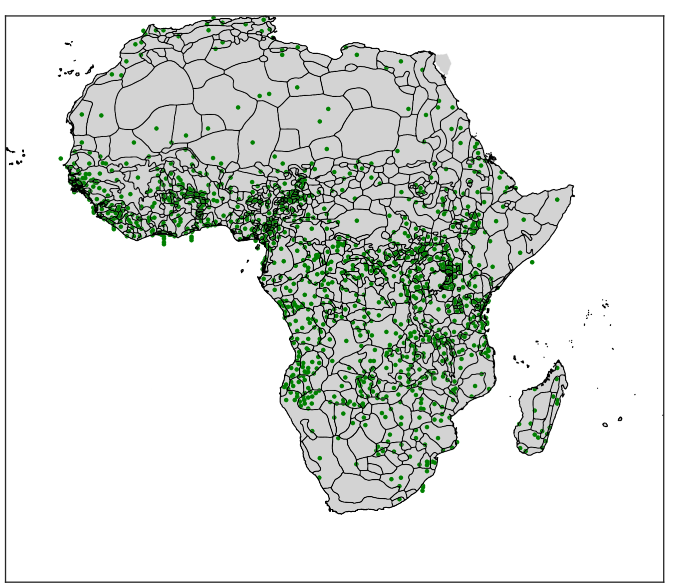

(a) Historical Borders \& Atlas Centroids of Ethnic Homelands

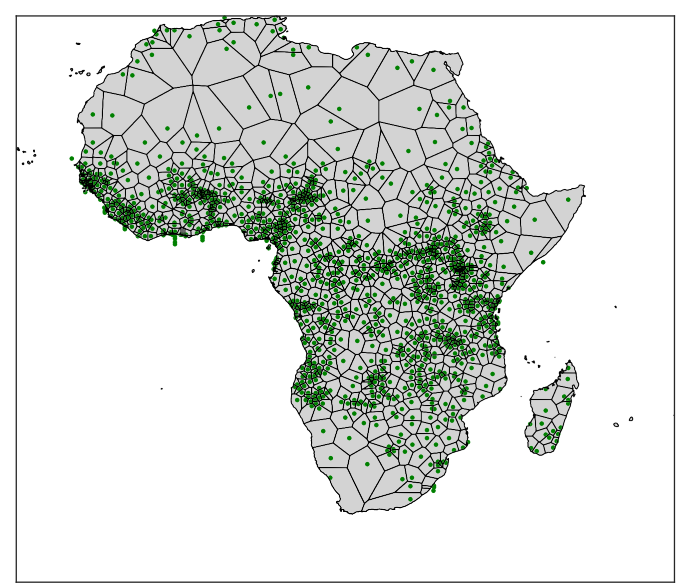

(b) Potential Borders \& Atlas Centroids of Ethnic Homelands

Figure C.6: Historical Ethnic Borders, Atlas Centroids and Atlas Potential (Voronoi) Borders in Africa

Table C.32: Historical Ethnic Borders and Conflict (IV) Robustness to Centroid Location (atlas)

\begin{tabular}{|c|c|c|c|c|c|c|c|}
\hline & \multicolumn{7}{|c|}{ Conflict } \\
\hline & \multirow{2}{*}{\multicolumn{2}{|c|}{$\begin{array}{c}\text { Prevalence } \\
\text { Presence }\end{array}$}} & \multicolumn{3}{|c|}{ Intensity } & \multicolumn{2}{|r|}{ Onset } \\
\hline & & & \multirow{2}{*}{$\frac{\text { Events }}{(3)}$} & \multirow{2}{*}{$\frac{\text { Years }}{(4)}$} & \multirow{2}{*}{$\frac{\text { Fatalities }}{(5)}$} & \multirow{2}{*}{$\frac{\text { Onset }}{(6)}$} & \multirow{2}{*}{$\frac{\text { Number of onsets }}{(7)}$} \\
\hline & $(1)$ & $(2)$ & & & & & \\
\hline Presence of Ethnic Border & $\begin{array}{l}0.346^{* * *} \\
(0.087)\end{array}$ & $\begin{array}{l}0.351^{* * *} \\
(0.100)\end{array}$ & $\begin{array}{l}0.794^{* * *} \\
(0.177)\end{array}$ & $\begin{array}{l}0.074^{* * *} \\
(0.017)\end{array}$ & $\begin{array}{l}0.481^{* *} \\
(0.216)\end{array}$ & $\begin{array}{l}0.041 \\
(0.031)\end{array}$ & $\begin{array}{l}0.048 \\
(0.030)\end{array}$ \\
\hline Country FE & Yes & Yes & Yes & Yes & Yes & Yes & Yes \\
\hline Ethnic FE & Yes & Yes & Yes & Yes & Yes & Yes & Yes \\
\hline Main Controls & No & Yes & Yes & Yes & Yes & Yes & Yes \\
\hline First-stage F-statistic & 30.79 & 29.37 & 29.37 & 29.37 & 29.37 & 29.37 & 29.37 \\
\hline Mean Prevalence & 0.22 & 0.22 & 0.36 & 0.03 & 0.32 & 0.03 & 0.03 \\
\hline Adjusted- $R^{2}$ & 0.28 & 0.29 & 0.32 & 0.32 & 0.32 & 0.16 & 0.19 \\
\hline Observations & 14078 & 14078 & 14078 & 14078 & 14078 & 14078 & 14078 \\
\hline
\end{tabular}

Notes: Heteroskedasticity robust standard error estimates clustered at the country-level are reported in parentheses; $* * *$ denotes statistical significance at the $1 \%$ level, $* *$ at the $5 \%$ level, and * at the $10 \%$ level, all for two-sided hypothesis tests. 


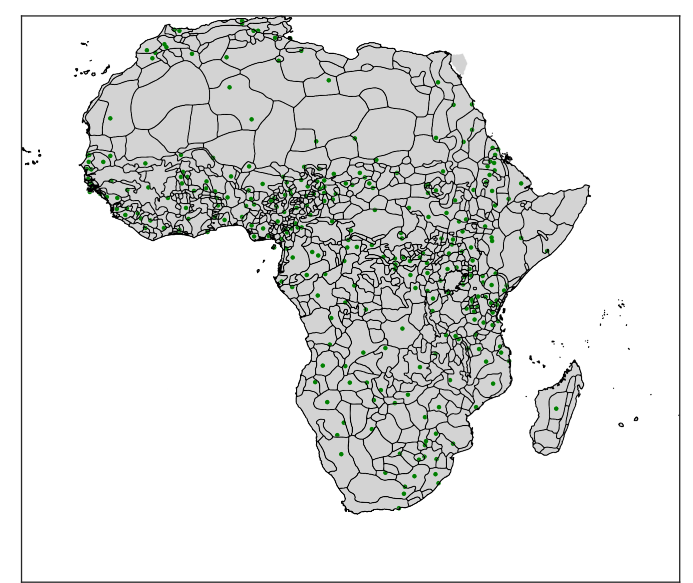

(a) Historical Borders \& GREG Centroids of Ethnic Homelands

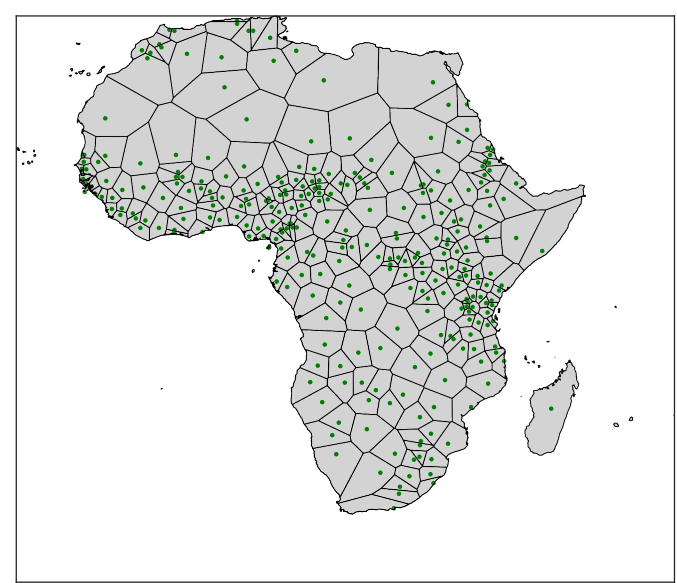

(b) Potential Borders \& GREG Centroids of Ethnic Homelands

Figure C.7: Historical Ethnic Borders, GREG Centroids and GREG Potential (Voronoi) Borders in Africa

Table C.33: Historical Ethnic Borders and Conflict (IV) Robustness to Centroid Location (greg)

\begin{tabular}{|c|c|c|c|c|c|c|c|}
\hline & \multicolumn{7}{|c|}{ Conflict } \\
\hline & \multirow{2}{*}{\multicolumn{2}{|c|}{$\begin{array}{c}\text { Prevalence } \\
\text { Presence }\end{array}$}} & \multicolumn{3}{|c|}{ Intensity } & \multicolumn{2}{|r|}{ Onset } \\
\hline & & & \multirow{2}{*}{$\frac{\text { Events }}{(3)}$} & \multirow{2}{*}{$\frac{\text { Years }}{(4)}$} & \multirow{2}{*}{$\frac{\text { Fatalities }}{(5)}$} & \multirow{2}{*}{$\frac{\text { Onset }}{(6)}$} & \multirow{2}{*}{$\frac{\text { Number of onsets }}{(7)}$} \\
\hline & $(1)$ & $(2)$ & & & & & \\
\hline Presence of Ethnic Border & $\begin{array}{l}0.216^{* *} \\
(0.091)\end{array}$ & $\begin{array}{l}0.215^{* *} \\
(0.100)\end{array}$ & $\begin{array}{l}0.536^{* * *} \\
(0.171)\end{array}$ & $\begin{array}{l}0.053^{* * *} \\
(0.020)\end{array}$ & $\begin{array}{l}0.390^{* *} \\
(0.172) \\
\end{array}$ & $\begin{array}{l}0.026 \\
(0.036) \\
\end{array}$ & $\begin{array}{l}0.027 \\
(0.033)\end{array}$ \\
\hline Country FE & Yes & Yes & Yes & Yes & Yes & Yes & Yes \\
\hline Ethnic FE & Yes & Yes & Yes & Yes & Yes & Yes & Yes \\
\hline Main Controls & No & Yes & Yes & Yes & Yes & Yes & Yes \\
\hline First-stage F-statistic & 21.57 & 19.80 & 19.80 & 19.80 & 19.80 & 19.80 & 19.80 \\
\hline Mean Prevalence & 0.22 & 0.22 & 0.36 & 0.03 & 0.32 & 0.03 & 0.03 \\
\hline Adjusted- $R^{2}$ & 0.31 & 0.31 & 0.35 & 0.34 & 0.33 & 0.17 & 0.19 \\
\hline Observations & 14078 & 14078 & 14078 & 14078 & 14078 & 14078 & 14078 \\
\hline
\end{tabular}

Notes: Heteroskedasticity robust standard error estimates clustered at the country-level are reported in parentheses; ${ }^{* * *}$ denotes statistical significance at the $1 \%$ level, ${ }^{* *}$ at the $5 \%$ level, and ${ }^{*}$ at the $10 \%$ level, all for two-sided hypothesis tests. 
Table C.34: Historical Ethnic Borders and Conflict (IV) Alternative Ethnic Map (GREG)

\begin{tabular}{|c|c|c|c|c|c|c|c|}
\hline & \multicolumn{7}{|c|}{ Conflict } \\
\hline & \multirow{2}{*}{\multicolumn{2}{|c|}{$\begin{array}{c}\text { Prevalence } \\
\text { Presence }\end{array}$}} & \multicolumn{3}{|c|}{ Intensity } & \multicolumn{2}{|r|}{ Onset } \\
\hline & & & \multirow{2}{*}{$\frac{\text { Events }}{(3)}$} & \multirow{2}{*}{$\frac{\text { Years }}{(4)}$} & \multirow{2}{*}{$\frac{\text { Fatalities }}{(5)}$} & \multirow{2}{*}{$\frac{\text { Onset }}{(6)}$} & \multirow{2}{*}{$\frac{\text { Number of onsets }}{(7)}$} \\
\hline & (1) & $(2)$ & & & & & \\
\hline \multirow[t]{2}{*}{ Ethnic Borders (GREG) } & $0.181^{* *}$ & $0.167^{* *}$ & $0.415^{* * *}$ & $0.041^{* * *}$ & $0.303^{* *}$ & 0.020 & 0.021 \\
\hline & $(0.079)$ & $(0.080)$ & $(0.139)$ & $(0.016)$ & $(0.134)$ & $(0.028)$ & $(0.025)$ \\
\hline Country FE & Yes & Yes & Yes & Yes & Yes & Yes & Yes \\
\hline Ethnic FE & Yes & Yes & Yes & Yes & Yes & Yes & Yes \\
\hline Main Controls & No & Yes & Yes & Yes & Yes & Yes & Yes \\
\hline First-stage F-statistic & 20.43 & 18.99 & 18.99 & 18.99 & 18.99 & 18.99 & 18.99 \\
\hline Mean Prevalence & 0.22 & 0.22 & 0.36 & 0.03 & 0.32 & 0.03 & 0.03 \\
\hline Adjusted- $R^{2}$ & 0.30 & 0.31 & 0.35 & 0.34 & 0.33 & 0.17 & 0.20 \\
\hline Observations & 14078 & 14078 & 14078 & 14078 & 14078 & 14078 & 14078 \\
\hline
\end{tabular}

Notes: Heteroskedasticity robust standard error estimates clustered at the country-level are reported in parentheses; *** denotes statistical significance at the $1 \%$ level, ** at the $5 \%$ level, and * at the $10 \%$ level, all for two-sided hypothesis tests.

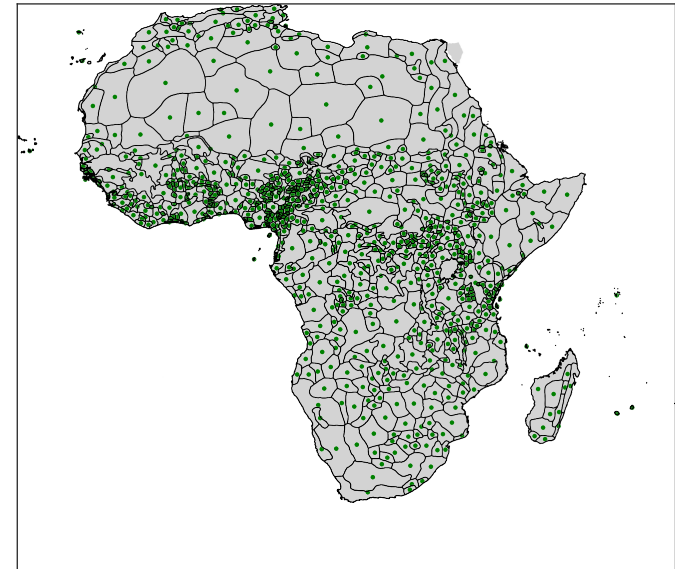

(a) Historical Borders \& Centroids of Ethnic Homelands

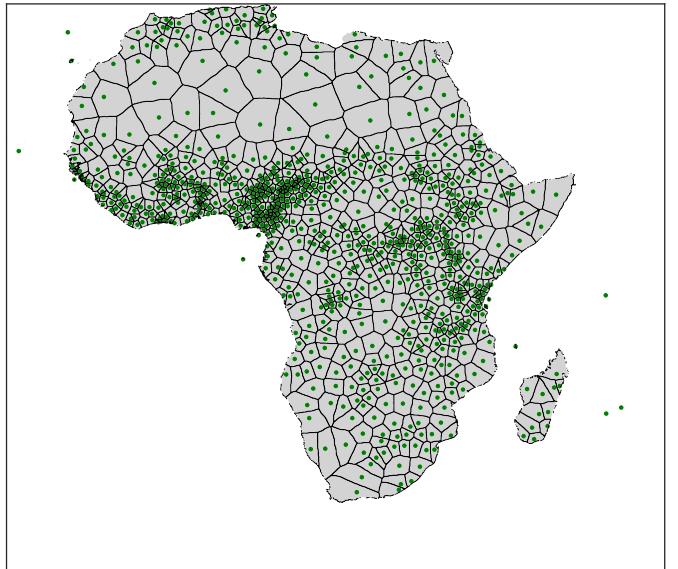

(b) Potential Borders \& Centroids of Ethnic Homelands

Figure C.8: Historical Ethnic Borders, Centroids and Potential (Voronoi) Borders in Africa Robustness to Voronoi Construction (HMI) 
Table C.35: Historical Ethnic Borders and Conflict (IV) Robustness to Voronoi Construction (HMI)

\begin{tabular}{|c|c|c|c|c|c|c|c|}
\hline & \multicolumn{7}{|c|}{ Conflict } \\
\hline & \multirow{2}{*}{\multicolumn{2}{|c|}{$\begin{array}{c}\text { Prevalence } \\
\text { Presence }\end{array}$}} & \multicolumn{3}{|c|}{ Intensity } & \multicolumn{2}{|r|}{ Onset } \\
\hline & & & \multirow{2}{*}{$\frac{\text { Events }}{(3)}$} & \multirow{2}{*}{$\frac{\text { Years }}{(4)}$} & \multirow{2}{*}{$\frac{\text { Fatalities }}{(5)}$} & \multirow{2}{*}{$\frac{\text { Onset }}{(6)}$} & \multirow{2}{*}{$\frac{\text { Number of onsets }}{(7)}$} \\
\hline & $(1)$ & $(2)$ & & & & & \\
\hline Presence of Ethnic Border & $\begin{array}{l}0.279 * * * \\
(0.066)\end{array}$ & $\begin{array}{l}0.283^{* * *} \\
(0.069)\end{array}$ & $\begin{array}{l}0.560 * * * \\
(0.138)\end{array}$ & $\begin{array}{l}0.048^{* * *} \\
(0.014)\end{array}$ & $\begin{array}{l}0.505^{* * *} \\
(0.123)\end{array}$ & $\begin{array}{l}0.102^{* * *} \\
(0.032)\end{array}$ & $\begin{array}{l}0.100 * * * \\
(0.030)\end{array}$ \\
\hline Country FE & Yes & Yes & Yes & Yes & Yes & Yes & Yes \\
\hline Ethnic FE & Yes & Yes & Yes & Yes & Yes & Yes & Yes \\
\hline Main Controls & No & Yes & Yes & Yes & Yes & Yes & Yes \\
\hline First-stage F-statistic & 37.67 & 37.29 & 37.29 & 37.29 & 37.29 & 37.29 & 37.29 \\
\hline Mean Prevalence & 0.22 & 0.22 & 0.36 & 0.03 & 0.32 & 0.03 & 0.03 \\
\hline Adjusted- $R^{2}$ & 0.29 & 0.30 & 0.35 & 0.35 & 0.32 & 0.14 & 0.17 \\
\hline Observations & 14078 & 14078 & 14078 & 14078 & 14078 & 14078 & 14078 \\
\hline
\end{tabular}

Notes: Heteroskedasticity robust standard error estimates clustered at the country-level are reported in parentheses; ${ }^{* * *}$ denotes statistical significance at the $1 \%$ level, $* *$ at the $5 \%$ level, and * at the $10 \%$ level, all for two-sided hypothesis tests. Main Controls refer to the sets of Geographic and Climatic controls described in Table 1. 


\section{C.2.14 Robustness to Non-classical Measurement Error}

Table C.36: Historical Ethnic Borders and Conflict (OLS) Lower Bounds Under Non-Classical Measurement Error

\begin{tabular}{lllllll}
\hline \hline & \multicolumn{5}{c}{ Prevalence of Conflict } \\
\cline { 2 - 7 } & \multicolumn{7}{c}{$(1)$} & $(2)$ & $(3)$ & $(4)$ & $(5)$ & $(6)$ \\
\hline Both Ethnic Borders Present & $0.232^{* * *}$ & $0.158^{* * *}$ & $0.104^{* * *}$ & $0.100^{* * *}$ & $0.090^{* * *}$ & $0.104^{* * *}$ \\
& $(0.036)$ & $(0.021)$ & $(0.022)$ & $(0.019)$ & $(0.019)$ & $(0.023)$ \\
\hline Country FE & No & Yes & Yes & Yes & Yes & Yes \\
Ethnic FE & No & No & Yes & Yes & Yes & Yes \\
Geographic Controls & No & No & No & Yes & Yes & Yes \\
Climatic Controls & No & No & No & No & Yes & Yes \\
Adjusted- $R^{2}$ & 0.04 & 0.19 & 0.33 & 0.34 & 0.34 & 0.37 \\
Observations & 14078 & 14078 & 14078 & 14078 & 14078 & 9333 \\
\hline
\end{tabular}

Notes: This table follows the method of Black et al. (2000) to estimate lower bounds for the effect of historical ethnic borders. Specifically, it shows the estimated OLS coefficient for the presence of both measures of historical ethnic borders relative to the absence of borders according to both measures. As Black et al. (2000) show the true effect under non-classical measurement error, due to truncation as in our setting, is bounded between this OLS estimate and the IV estimate in Table 3. Column 6 replicates column 5 for the subsample where both measures are in agreement. Heteroskedasticity robust standard error estimates clustered at the country-level are reported in parentheses; denotes statistical significance at the $1 \%$ level, at the $5 \%$ level, and at the $10 \%$ level, all for two-sided hypothesis tests. 


\section{C.3 Mechanisms}

\section{C.3.1 Population Pressure}

Table C.37: Historical Ethnic Borders and Conflict (IV)

Heterogeneous Effect: Growth in Population Density

\begin{tabular}{|c|c|c|c|c|c|c|}
\hline & \multicolumn{6}{|c|}{ Prevalence of Conflict } \\
\hline & \multicolumn{3}{|c|}{ Non-Civil } & \multicolumn{3}{|c|}{ Ethnic } \\
\hline & 1900 & 1950 & 2000 & 1900 & 1950 & 2000 \\
\hline & $(1)$ & $(2)$ & $(3)$ & $(4)$ & $(5)$ & $(6)$ \\
\hline Presence of Ethnic Border & $\begin{array}{l}0.276^{* * *} \\
(0.069)\end{array}$ & $\begin{array}{l}0.253^{* * *} \\
(0.067)\end{array}$ & $\begin{array}{l}0.223^{* * *} \\
(0.067)\end{array}$ & $\begin{array}{l}0.131^{* * *} \\
(0.049)\end{array}$ & $\begin{array}{l}0.122^{* *} \\
(0.049)\end{array}$ & $\begin{array}{l}0.110^{* *} \\
(0.048)\end{array}$ \\
\hline Interaction & $\begin{array}{l}0.026 \\
(0.039)\end{array}$ & $\begin{array}{l}0.075^{*} \\
(0.042)\end{array}$ & $\begin{array}{l}0.097 * * * \\
(0.037)\end{array}$ & $\begin{array}{l}0.005 \\
(0.021)\end{array}$ & $\begin{array}{l}0.030 \\
(0.025)\end{array}$ & $\begin{array}{l}0.041^{* *} \\
(0.020)\end{array}$ \\
\hline Main Effect & $\begin{array}{l}0.036^{* *} \\
(0.018)\end{array}$ & $\begin{array}{l}0.049^{* *} \\
(0.019)\end{array}$ & $\begin{array}{l}0.051^{* * *} \\
(0.017)\end{array}$ & $\begin{array}{l}0.017^{* *} \\
(0.008)\end{array}$ & $\begin{array}{l}0.021^{* *} \\
(0.009)\end{array}$ & $\begin{array}{l}0.018^{* *} \\
(0.007)\end{array}$ \\
\hline Log [Population Density 1800CE] & $\begin{array}{l}0.046^{* * *} \\
(0.011)\end{array}$ & $\begin{array}{l}0.055^{* * *} \\
(0.009)\end{array}$ & $\begin{array}{l}0.053^{* * *} \\
(0.008)\end{array}$ & $\begin{array}{l}0.018^{* * *} \\
(0.005)\end{array}$ & $\begin{array}{l}0.022^{* * *} \\
(0.005)\end{array}$ & $\begin{array}{l}0.020^{* * *} \\
(0.005)\end{array}$ \\
\hline Country FE & Yes & Yes & Yes & Yes & Yes & Yes \\
\hline Ethnic FE & Yes & Yes & Yes & Yes & Yes & Yes \\
\hline Main Controls & Yes & Yes & Yes & Yes & Yes & Yes \\
\hline First-stage F-statistic & 16.92 & 16.06 & 14.62 & 16.92 & 16.06 & 14.62 \\
\hline Mean Prevalence & 0.22 & 0.22 & 0.22 & 0.07 & 0.07 & 0.07 \\
\hline Adjusted- $R^{2}$ & 0.31 & 0.32 & 0.33 & 0.29 & 0.29 & 0.29 \\
\hline Observations & 14078 & 14078 & 14078 & 14078 & 14078 & 14078 \\
\hline
\end{tabular}

Notes: Heteroskedasticity robust standard error estimates clustered at the country-level are reported in parentheses; $* * *$ denotes statistical significance at the $1 \%$ level, ${ }^{* *}$ at the $5 \%$ level, and * at the $10 \%$ level, all for two-sided hypothesis tests. Main Controls refer to the sets of Geographic and Climatic controls described in Table 1. 


\section{C.3.2 Similarity and Conflict - IV}

Table C.38: Historical Ethnic Borders and Conflict (IV) Effect of Cultural Distances

\begin{tabular}{|c|c|c|c|c|c|c|c|}
\hline & \multicolumn{7}{|c|}{ Prevalence of Conflict } \\
\hline & $(1)$ & $(2)$ & $(3)$ & $(4)$ & $(5)$ & $(6)$ & $(7)$ \\
\hline Presence of Ethnic Border & $\begin{array}{l}0.275^{* * *} \\
(0.073)\end{array}$ & $\begin{array}{l}0.281^{* * *} \\
(0.077)\end{array}$ & $\begin{array}{l}0.279 * * * \\
(0.076)\end{array}$ & $\begin{array}{l}0.278^{* * *} \\
(0.075)\end{array}$ & $\begin{array}{l}0.272^{* * *} \\
(0.073)\end{array}$ & $\begin{array}{l}0.275^{* * *} \\
(0.074)\end{array}$ & $\begin{array}{l}0.245^{* * *} \\
(0.067)\end{array}$ \\
\hline Cultural Distance (All) & & $\begin{array}{l}-0.087^{* * *} \\
(0.030)\end{array}$ & & & & & \\
\hline Cultural Distance (All85) & & & $\begin{array}{l}-0.082^{* * *} \\
(0.030)\end{array}$ & & & & \\
\hline Cultural Distance (Subsistence) & & & & $\begin{array}{l}-0.069^{* * *} \\
(0.025)\end{array}$ & & & \\
\hline Cultural Distance (Subsistencec) & & & & & $\begin{array}{l}-0.048^{* * *} \\
(0.019)\end{array}$ & & \\
\hline Cultural Distance (State) & & & & & & $\begin{array}{l}-0.055^{* * *} \\
(0.019)\end{array}$ & \\
\hline Cultural Distance (Statec) & & & & & & & $\begin{array}{l}-0.036^{* * *} \\
(0.012)\end{array}$ \\
\hline Country FE & Yes & Yes & Yes & Yes & Yes & Yes & Yes \\
\hline Ethnic FE & Yes & Yes & Yes & Yes & Yes & Yes & Yes \\
\hline Main Controls & Yes & Yes & Yes & Yes & Yes & Yes & Yes \\
\hline First-stage F-statistic & 23.47 & 22.49 & 23.02 & 23.59 & 23.54 & 23.86 & 26.02 \\
\hline Adjusted- $R^{2}$ & 0.32 & 0.33 & 0.33 & 0.33 & 0.33 & 0.33 & 0.33 \\
\hline Observations & 10131 & 10131 & 10131 & 10131 & 10131 & 10131 & 9826 \\
\hline
\end{tabular}

Notes: Heteroskedasticity robust standard error estimates clustered at the country-level are reported in parentheses; *** denotes statistical significance at the $1 \%$ level, ${ }^{* *}$ at the $5 \%$ level, and $*$ at the $10 \%$ level, all for two-sided hypothesis tests. Main Controls refer to the sets of Geographic and Climatic controls described in Table 1. 
Table C.39: Historical Ethnic Borders and Conflict (IV) Effect of Cultural Distances

\begin{tabular}{|c|c|c|c|c|c|c|c|}
\hline & \multicolumn{7}{|c|}{ Prevalence of Conflict } \\
\hline & $(1)$ & $(2)$ & $(3)$ & $(4)$ & $(5)$ & $(6)$ & $(7)$ \\
\hline Presence of Ethnic Border & $\begin{array}{l}0.347^{* * *} \\
(0.063)\end{array}$ & $\begin{array}{l}0.354^{* * *} \\
(0.069)\end{array}$ & $\begin{array}{l}0.349 * * * \\
(0.067)\end{array}$ & $\begin{array}{l}0.351^{* * *} \\
(0.065)\end{array}$ & $\begin{array}{l}0.339 * * * \\
(0.063)\end{array}$ & $\begin{array}{l}0.344^{* * *} \\
(0.066)\end{array}$ & $\begin{array}{l}0.294^{* * *} \\
(0.056)\end{array}$ \\
\hline Cultural Distance (All) & & $\begin{array}{l}-0.120^{* * *} \\
(0.031)\end{array}$ & & & & & \\
\hline Cultural Distance (All85) & & & $\begin{array}{l}-0.115^{* * *} \\
(0.030)\end{array}$ & & & & \\
\hline Cultural Distance (Subsistence) & & & & $\begin{array}{l}-0.095^{* * *} \\
(0.023)\end{array}$ & & & \\
\hline Cultural Distance (Subsistencec) & & & & & $\begin{array}{l}-0.064^{* * *} \\
(0.020)\end{array}$ & & \\
\hline Cultural Distance (State) & & & & & & $\begin{array}{l}-0.073^{* * *} \\
(0.019)\end{array}$ & \\
\hline Cultural Distance (Statec) & & & & & & & $\begin{array}{l}-0.046^{* * *} \\
(0.012)\end{array}$ \\
\hline Country FE & Yes & Yes & Yes & Yes & Yes & Yes & Yes \\
\hline Ethnic FE & Yes & Yes & Yes & Yes & Yes & Yes & Yes \\
\hline Main Controls & Yes & Yes & Yes & Yes & Yes & Yes & Yes \\
\hline First-stage F-statistic & 28.51 & 26.44 & 27.42 & 28.45 & 27.63 & 28.32 & 33.80 \\
\hline Adjusted- $R^{2}$ & 0.30 & 0.31 & 0.31 & 0.31 & 0.30 & 0.31 & 0.31 \\
\hline Observations & 8127 & 8127 & 8127 & 8127 & 8127 & 8127 & 7822 \\
\hline
\end{tabular}

Notes: Heteroskedasticity robust standard error estimates clustered at the country-level are reported in parentheses; $* * *$ denotes statistical significance at the $1 \%$ level, $* *$ at the $5 \%$ level, and $*$ at the $10 \%$ level, all for two-sided hypothesis tests. Main Controls refer to the sets of Geographic and Climatic controls described in Table 1. 
Table C.40: Historical Ethnic Borders and Conflict (IV) Effect of Linguistic Distances

\begin{tabular}{|c|c|c|c|c|c|c|c|}
\hline & \multicolumn{7}{|c|}{ Prevalence of Conflict } \\
\hline & $(1)$ & $(2)$ & $(3)$ & $(4)$ & $(5)$ & (6) & $(7)$ \\
\hline Presence of Ethnic Border & $\begin{array}{l}0.275^{* * *} \\
(0.073)\end{array}$ & $\begin{array}{l}0.274^{* * *} \\
(0.072)\end{array}$ & $\begin{array}{l}0.274^{* * *} \\
(0.073)\end{array}$ & $\begin{array}{l}0.273^{* * *} \\
(0.073)\end{array}$ & $\begin{array}{l}0.273^{* * *} \\
(0.073)\end{array}$ & $\begin{array}{l}0.275^{* * *} \\
(0.074)\end{array}$ & $\begin{array}{l}0.281^{* * *} \\
(0.076)\end{array}$ \\
\hline Linguistic Distance (Level 1) & & $\begin{array}{l}-0.012 \\
(0.007)\end{array}$ & & & & & \\
\hline Linguistic Distance (Level 3) & & & $\begin{array}{c}-0.019 * \\
(0.011)\end{array}$ & & & & \\
\hline Linguistic Distance (Level 5) & & & & $\begin{array}{l}-0.029^{* *} \\
(0.015)\end{array}$ & & & \\
\hline Linguistic Distance (Level 7) & & & & & $\begin{array}{l}-0.036^{* *} \\
(0.017)\end{array}$ & & \\
\hline Linguistic Distance (Level 10) & & & & & & $\begin{array}{l}-0.049 * * \\
(0.020)\end{array}$ & \\
\hline Linguistic Distance (Level 15) & & & & & & & $\begin{array}{l}-0.066^{* * *} \\
(0.025)\end{array}$ \\
\hline Country FE & Yes & Yes & Yes & Yes & Yes & Yes & Yes \\
\hline Ethnic FE & Yes & Yes & Yes & Yes & Yes & Yes & Yes \\
\hline Main Controls & Yes & Yes & Yes & Yes & Yes & Yes & Yes \\
\hline First-stage F-statistic & 23.46 & 23.66 & 23.33 & 23.74 & 23.84 & 23.41 & 22.86 \\
\hline Adjusted- $R^{2}$ & 0.32 & 0.32 & 0.32 & 0.32 & 0.32 & 0.32 & 0.33 \\
\hline Observations & 10130 & 10130 & 10130 & 10130 & 10130 & 10130 & 10130 \\
\hline
\end{tabular}

Notes: Heteroskedasticity robust standard error estimates clustered at the country-level are reported in parentheses; *** denotes statistical significance at the $1 \%$ level, ${ }^{* *}$ at the $5 \%$ level, and * at the $10 \%$ level, all for two-sided hypothesis tests. Main Controls refer to the sets of Geographic and Climatic controls described in Table 1. 
Table C.41: Historical Ethnic Borders and Conflict (IV) Effect of Linguistic Distances

\begin{tabular}{|c|c|c|c|c|c|c|c|}
\hline & \multicolumn{7}{|c|}{ Prevalence of Conflict } \\
\hline & $(1)$ & $(2)$ & $(3)$ & $(4)$ & $(5)$ & $(6)$ & $(7)$ \\
\hline Presence of Ethnic Border & $\begin{array}{l}0.347^{* * *} \\
(0.063)\end{array}$ & $\begin{array}{l}0.343^{* * *} \\
(0.063)\end{array}$ & $\begin{array}{l}0.343^{* * *} \\
(0.063)\end{array}$ & $\begin{array}{l}0.340^{* * *} \\
(0.063)\end{array}$ & $\begin{array}{l}0.340^{* * *} \\
(0.063)\end{array}$ & $\begin{array}{l}0.344^{* * *} \\
(0.065)\end{array}$ & $\begin{array}{l}0.355^{* * *} \\
(0.068)\end{array}$ \\
\hline Linguistic Distance (Level 1) & & $\begin{array}{l}-0.015^{* *} \\
(0.008)\end{array}$ & & & & & \\
\hline Linguistic Distance (Level 3) & & & $\begin{array}{l}-0.028^{* * *} \\
(0.011)\end{array}$ & & & & \\
\hline Linguistic Distance (Level 5) & & & & $\begin{array}{l}-0.042^{* * *} \\
(0.015)\end{array}$ & & & \\
\hline Linguistic Distance (Level 7) & & & & & $\begin{array}{l}-0.051^{* * *} \\
(0.017)\end{array}$ & & \\
\hline Linguistic Distance (Level 10) & & & & & & $\begin{array}{l}-0.068^{* * *} \\
(0.020)\end{array}$ & \\
\hline Linguistic Distance (Level 15) & & & & & & & $\begin{array}{l}-0.092^{* * *} \\
(0.024)\end{array}$ \\
\hline Country FE & Yes & Yes & Yes & Yes & Yes & Yes & Yes \\
\hline Ethnic FE & Yes & Yes & Yes & Yes & Yes & Yes & Yes \\
\hline Main Controls & Yes & Yes & Yes & Yes & Yes & Yes & Yes \\
\hline First-stage F-statistic & 28.50 & 28.53 & 27.60 & 28.19 & 28.32 & 27.49 & 27.09 \\
\hline Adjusted- $R^{2}$ & 0.30 & 0.30 & 0.30 & 0.30 & 0.30 & 0.30 & 0.31 \\
\hline Observations & 8126 & 8126 & 8126 & 8126 & 8126 & 8126 & 8126 \\
\hline
\end{tabular}

Notes: Heteroskedasticity robust standard error estimates clustered at the country-level are reported in parentheses; *** denotes statistical significance at the $1 \%$ level, ${ }^{* *}$ at the $5 \%$ level, and * at the $10 \%$ level, all for two-sided hypothesis tests. Main Controls refer to the sets of Geographic and Climatic controls described in Table 1. 


\section{C.3.3 Hard vs. Soft Borders (Interaction with Cell-level) - IV}

Table C.42: Historical Ethnic Borders and Conflict (IV) Hard vs. Soft Borders

\begin{tabular}{|c|c|c|c|c|c|c|c|}
\hline & \multicolumn{7}{|c|}{ Prevalence of Conflict } \\
\hline & \multirow[t]{2}{*}{ Main } & \multirow[t]{2}{*}{ Elevation } & \multirow[t]{2}{*}{ River } & \multirow[t]{2}{*}{ Coast } & \multicolumn{2}{|c|}{ EcologicalAdm1 } & \multirow{2}{*}{$\begin{array}{l}\text { National } \\
\text { Border }\end{array}$} \\
\hline & & & & & Border & Border & \\
\hline & $(1)$ & $(2)$ & $(3)$ & $(4)$ & $(5)$ & $(6)$ & $(7)$ \\
\hline \multirow[t]{2}{*}{ Presence of Ethnic Border } & $0.273^{* * *}$ & $0.234^{* * *}$ & $0.271^{* * *}$ & $0.246^{* * *}$ & $0.228^{* * *}$ & $0.265^{* * *}$ & $0.241^{* * *}$ \\
\hline & $(0.066)$ & $(0.077)$ & $(0.065)$ & $(0.079)$ & $(0.067)$ & $(0.067)$ & $(0.070)$ \\
\hline \multirow[t]{2}{*}{ Interaction } & & -0.072 & -0.003 & -0.018 & 0.000 & 0.031 & $0.078^{* * *}$ \\
\hline & & $(0.054)$ & $(0.027)$ & $(0.063)$ & $(0.030)$ & $(0.028)$ & $(0.021)$ \\
\hline \multirow[t]{2}{*}{ Main Effect } & & $0.055^{* * *}$ & $0.033^{*}$ & 0.026 & 0.029 & -0.013 & $-0.059^{* * *}$ \\
\hline & & $(0.014)$ & $(0.019)$ & $(0.060)$ & $(0.021)$ & $(0.019)$ & $(0.014)$ \\
\hline Country FE & Yes & Yes & Yes & Yes & Yes & Yes & Yes \\
\hline Ethnic FE & Yes & Yes & Yes & Yes & Yes & Yes & Yes \\
\hline Main Controls & Yes & Yes & Yes & Yes & Yes & Yes & Yes \\
\hline First-stage F-statistic & 34.14 & 20.05 & 19.31 & 19.11 & 16.29 & 17.51 & 18.21 \\
\hline Adjusted- $R^{2}$ & 0.30 & 0.31 & 0.31 & 0.31 & 0.31 & 0.30 & 0.31 \\
\hline Observations & 14078 & 14078 & 14078 & 14078 & 14078 & 14078 & 14078 \\
\hline
\end{tabular}

Notes: Heteroskedasticity robust standard error estimates clustered at the country-level are reported in parentheses; ${ }^{* * *}$ denotes statistical significance at the $1 \%$ level, ${ }^{* *}$ at the $5 \%$ level, and ${ }^{*}$ at the $10 \%$ level, all for two-sided hypothesis tests. Main Controls refer to the sets of Geographic and Climatic controls described in Table 1.

\section{C.4 Types \& Causes of Conflict}


Table C.43: Historical Ethnic Borders and Conflict (IV) Effect on Conflict Type \& Onset

\begin{tabular}{|c|c|c|c|c|c|c|}
\hline & \multicolumn{6}{|c|}{ Prevalence of Conflict } \\
\hline & Non-Civil & Local & Ethnic & Land & Onset & $\begin{array}{l}\text { Number of } \\
\text { Onsets }\end{array}$ \\
\hline & $(1)$ & $(2)$ & $(3)$ & $(4)$ & $(5)$ & (6) \\
\hline Presence of Ethnic Border & $\begin{array}{l}0.273^{* * *} \\
(0.066)\end{array}$ & $\begin{array}{l}0.194 * * * \\
(0.066)\end{array}$ & $\begin{array}{l}0.130 * * * \\
(0.049)\end{array}$ & $\begin{array}{l}0.046 * * \\
(0.020)\end{array}$ & $\begin{array}{l}0.079 * * * \\
(0.025)\end{array}$ & $\begin{array}{l}0.075^{* * *} \\
(0.023)\end{array}$ \\
\hline Country FE & Yes & Yes & Yes & Yes & Yes & Yes \\
\hline Ethnic FE & Yes & Yes & Yes & Yes & Yes & Yes \\
\hline Main Controls & Yes & Yes & Yes & Yes & Yes & Yes \\
\hline First-stage F-statistic & 34.14 & 34.14 & 34.14 & 34.14 & 34.14 & 34.14 \\
\hline Mean Prevalence & 0.22 & 0.16 & 0.07 & 0.03 & 0.03 & 0.03 \\
\hline Adjusted- $R^{2}$ & 0.30 & 0.28 & 0.28 & 0.17 & 0.15 & 0.18 \\
\hline Observations & 14078 & 14078 & 14078 & 14078 & 14078 & 14078 \\
\hline
\end{tabular}

Notes: Heteroskedasticity robust standard error estimates clustered at the country-level are reported in parentheses; *** denotes statistical significance at the $1 \%$ level, $* *$ at the $5 \%$ level, and $*$ at the $10 \%$ level, all for two-sided hypothesis tests. Main Controls refer to the sets of Geographic and Climatic controls described in Table 1.

Table C.44: Historical Ethnic Borders and Conflict (IV) Effect by Conflict Cause

\begin{tabular}{|c|c|c|c|c|c|c|c|c|c|}
\hline & \multicolumn{9}{|c|}{ Prevalence of Conflict } \\
\hline & $\begin{array}{l}\text { Non- } \\
\text { Civil }\end{array}$ & $\begin{array}{l}\text { Com- } \\
\text { munal }\end{array}$ & $\begin{array}{l}\text { Terri- } \\
\text { tory }\end{array}$ & $\begin{array}{l}\text { Au- } \\
\text { thority }\end{array}$ & Other & $\begin{array}{l}\text { Agr. } \\
\text { Land } \\
\& \text { Wa- } \\
\text { ter }\end{array}$ & $\begin{array}{l}\text { Other } \\
\text { Terri- } \\
\text { torial }\end{array}$ & $\begin{array}{l}\text { Live- } \\
\text { stock }\end{array}$ & $\begin{array}{l}\text { Religi- } \\
\text { ous }\end{array}$ \\
\hline & $(1)$ & $(2)$ & $(3)$ & $(4)$ & $(5)$ & $(6)$ & $(7)$ & $(8)$ & $(9)$ \\
\hline Presence of Ethnic Border & $\begin{array}{l}0.307^{* * *} \\
(0.095)\end{array}$ & $\begin{array}{l}0.067 \\
(0.042)\end{array}$ & $\begin{array}{l}0.065^{*} \\
(0.039)\end{array}$ & $\begin{array}{l}0.044^{*} \\
(0.023)\end{array}$ & $\begin{array}{l}0.047^{* *} \\
(0.024)\end{array}$ & $\begin{array}{l}0.019 \\
(0.023)\end{array}$ & $\begin{array}{l}0.071^{* * *} \\
(0.027)\end{array}$ & $\begin{array}{l}0.034^{*} \\
(0.019)\end{array}$ & $\begin{array}{l}-0.001 \\
(0.005)\end{array}$ \\
\hline Country FE & Yes & Yes & Yes & Yes & Yes & Yes & Yes & Yes & Yes \\
\hline Ethnic FE & Yes & Yes & Yes & Yes & Yes & Yes & Yes & Yes & Yes \\
\hline Main Controls & Yes & Yes & Yes & Yes & Yes & Yes & Yes & Yes & Yes \\
\hline First-stage F-statistic & 16.34 & 16.34 & 16.34 & 16.34 & 16.34 & 16.34 & 16.34 & 16.34 & 16.34 \\
\hline Mean Prevalence & 0.24 & 0.05 & 0.04 & 0.02 & 0.03 & 0.03 & 0.03 & 0.02 & 0.01 \\
\hline Adjusted- $R^{2}$ & 0.30 & 0.31 & 0.31 & 0.34 & 0.30 & 0.26 & 0.31 & 0.34 & 0.41 \\
\hline Observations & 9973 & 9973 & 9973 & 9973 & 9973 & 9973 & 9973 & 9973 & 9973 \\
\hline
\end{tabular}

Notes: Heteroskedasticity robust standard error estimates clustered at the country-level are reported in parentheses; *** denotes statistical significance at the $1 \%$ level, $* *$ at the $5 \%$ level, and $*$ at the $10 \%$ level, all for two-sided hypothesis tests. Main Controls refer to the sets of Geographic and Climatic controls described in Table 1. 


\section{Random Allocation of Ethnic Borders Status (IV)}

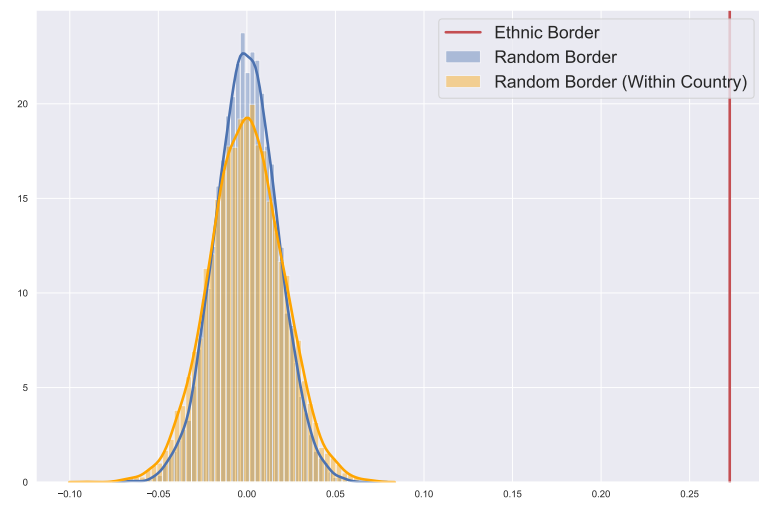

(a) Cell Size $50 \times 50$

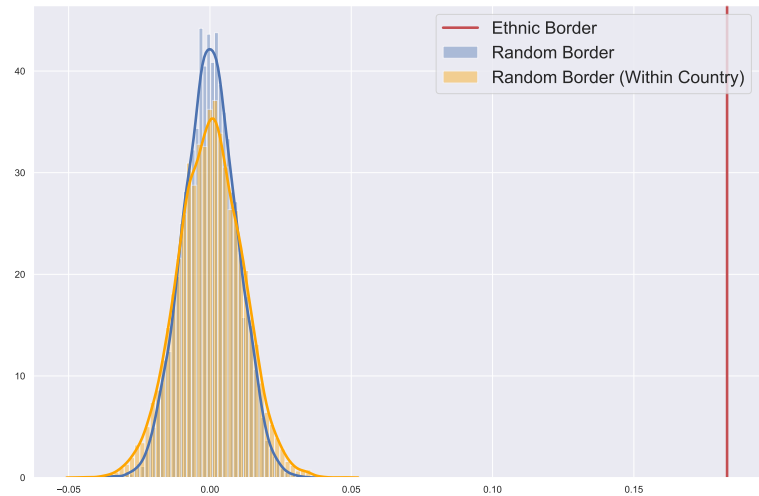

(c) Cell Size $25 \times 25$

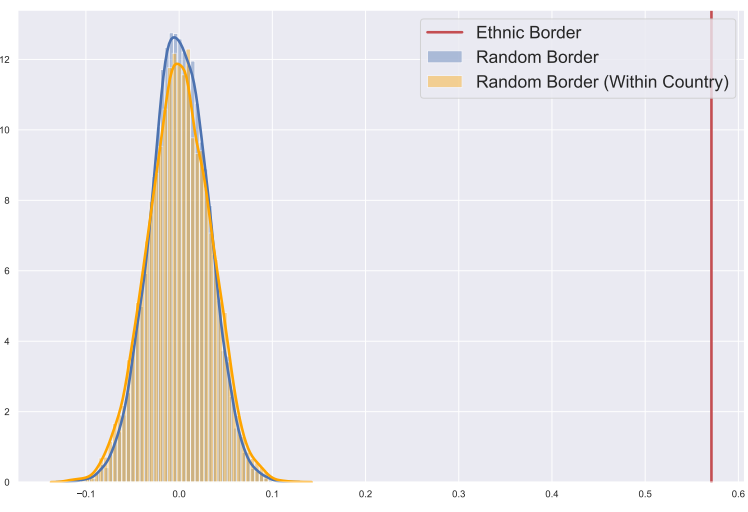

(b) Cell Size $100 \times 100$

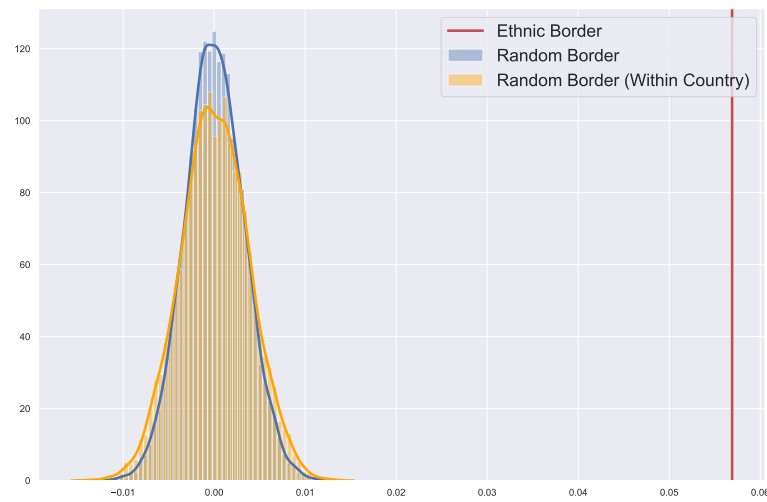

(d) Cell Size $10 \times 10$

Figure D.1: Placebo Test: Ethnic vs. Random Border Status (IV) 


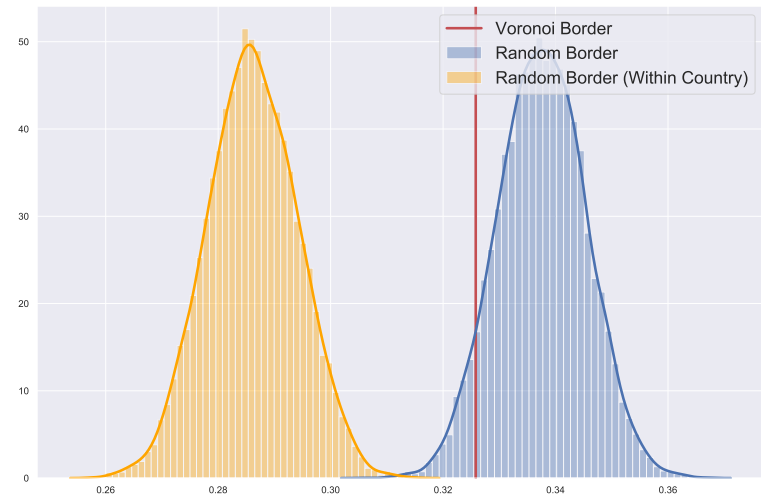

(a) Cell Size $50 \times 50$

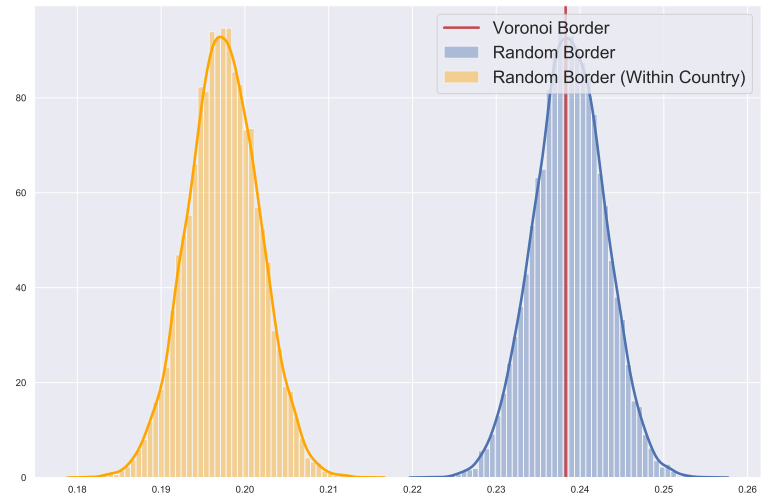

(c) Cell Size $25 \times 25$

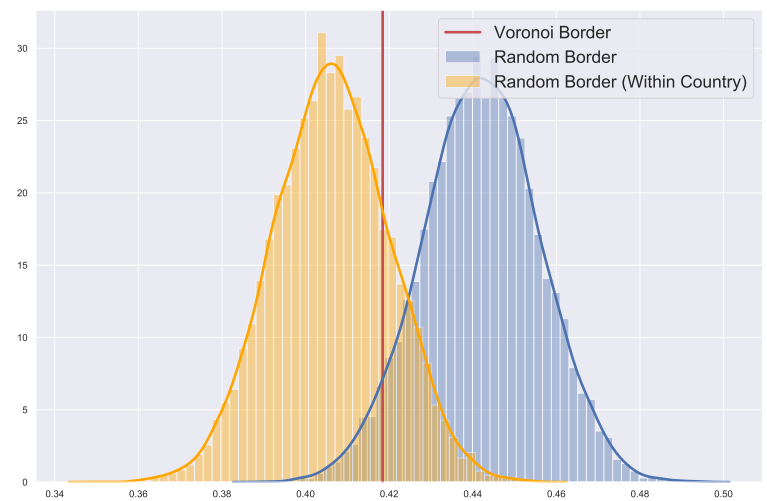

(b) Cell Size $100 \times 100$

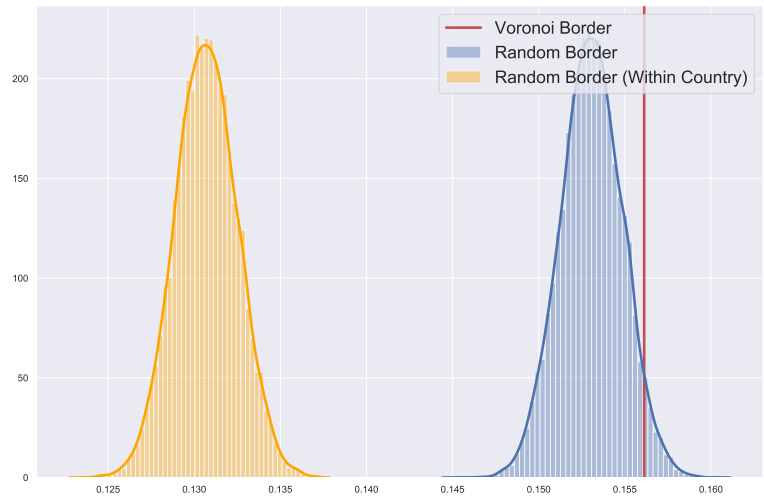

(d) Cell Size $10 \times 10$

Figure D.2: Placebo Test: Ethnic vs. Random Border Status (First-Stage) 


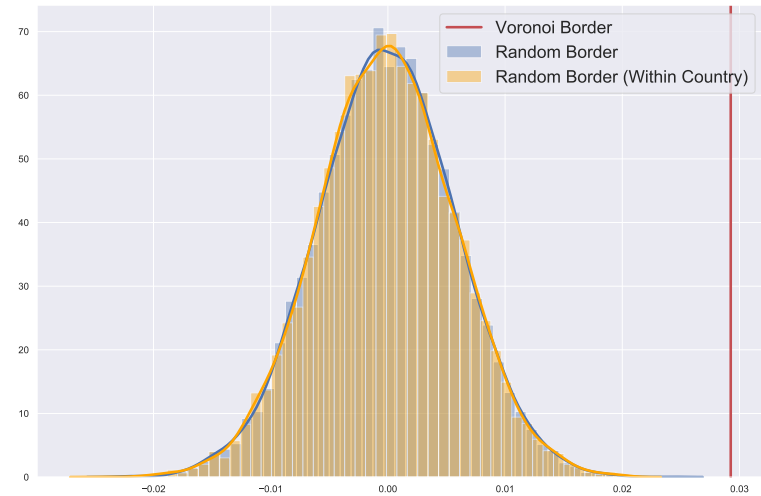

(a) Cell Size $50 \times 50$

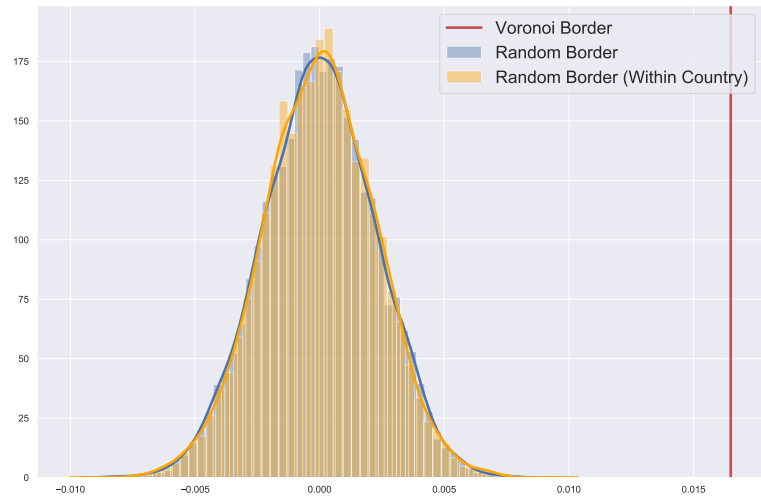

(c) Cell Size $25 \times 25$

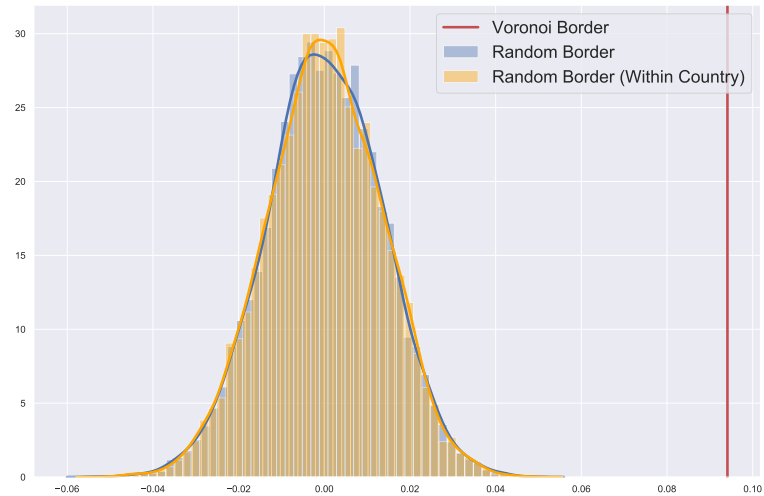

(b) Cell Size $100 \times 100$

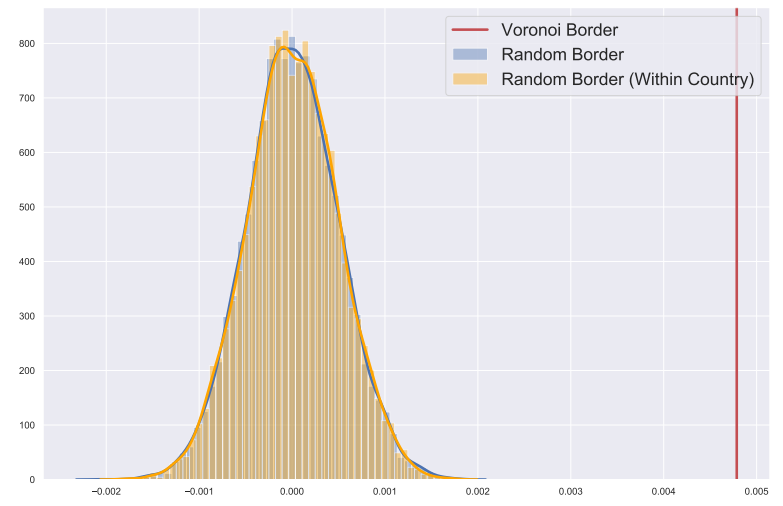

(d) Cell Size $10 \times 10$

Figure D.3: Placebo Test: Ethnic vs. Random Border Status (Reduced Form) 


\section{E Variable Definitions, Sources and Summary Statistics}

This section presents the definition, sources, and summary statistics for the variables used in the different analyses in the main body of the paper.

\section{E.1 Variable Definition and Sources}

- Absolute latitude: The absolute value of the latitude of cell's geodesic centroid. Author's computations.

- Longitude: The longitude of cell's geodesic centroid. Author's computations.

- Mean Elevation: The mean elevation of a homeland in $\mathrm{km}$ above sea level, calculated using geospatial elevation data taken from GLOBE Task Team and others (1999). Author's computations.

- Terrain Ruggedness: The mean change in elevation across cells in a homeland in $\mathrm{km}$, calculated following the methodology of Riley et al. (1999), using geospatial elevation data taken from GLOBE Task Team and others (1999). Author's computations.

- Caloric Suitability: Pre-1500CE Caloric suitability is the potential caloric output in a region as reported in Galor and Özak (2015) and Galor and Özak (2016).

- Land Suitability: Average probability within a region that a particular grid cell will be cultivated as computed by Ramankutty et al. (2002).

- Coast length: Length, in thousands of km, of a country's coastline. Author's computations.

- Ecological Diversity: Herfindahl index of share's of a country's area in various ecologies. Author's computations following the method of Fenske (2014) and Depetris-Chauvin and Özak (2016).

- Share of Area within 100kms of Sea: Share of a country's area within 100kms of Sea. Author's computations.

- Share of Area within 100kms of Waterbodies: Share of a country's area within 100kms of waterbody (perennial, fluctuating). Author's computations.

- Climate variables (temperature, precipitation, etc.): Mean and standard deviation of climatic characteristics (e.g., temperature and precipitation) constructed using v3.2 of the Climatic Research Unit (CRU) database. 


\section{F Robustness to Cell size}

\section{F.1 ACLED Dataset $100 \times 100$}

Table F.1: Historical Ethnic Borders and Conflict (OLS)

\begin{tabular}{|c|c|c|c|c|c|c|c|c|}
\hline & \multicolumn{8}{|c|}{ Conflict } \\
\hline & \multicolumn{5}{|c|}{ Prevalence } & \multicolumn{3}{|c|}{ Intensity } \\
\hline & \multicolumn{5}{|c|}{ Presence } & \multirow{2}{*}{$\frac{\text { Events }}{(6)}$} & \multirow{2}{*}{$\frac{\text { Years }}{(7)}$} & \multirow{2}{*}{$\frac{\text { Fatalities }}{(8)}$} \\
\hline & (1) & $(2)$ & $(3)$ & (4) & $(5)$ & & & \\
\hline Presence of Ethnic Border & $\begin{array}{l}0.278^{* * *} \\
(0.024)\end{array}$ & $\begin{array}{l}0.208^{* * *} \\
(0.023)\end{array}$ & $\begin{array}{l}0.147^{* * *} \\
(0.026)\end{array}$ & $\begin{array}{l}0.136^{\text {*** }} \\
(0.026)\end{array}$ & $\begin{array}{l}0.125^{* * *} \\
(0.027)\end{array}$ & $\begin{array}{l}0.274^{* * *} \\
(0.078)\end{array}$ & $\begin{array}{l}0.027^{* * *} \\
(0.009)\end{array}$ & $\begin{array}{l}0.196^{* *} \\
(0.094)\end{array}$ \\
\hline Absolute Latitude & & & & $\begin{array}{l}0.025 \\
(0.044)\end{array}$ & $\begin{array}{l}0.087^{*} \\
(0.044)\end{array}$ & $\begin{array}{l}0.372^{* * *} \\
(0.126)\end{array}$ & $\begin{array}{l}0.031^{* *} \\
(0.012)\end{array}$ & $\begin{array}{l}0.086 \\
(0.136)\end{array}$ \\
\hline Longitude & & & & $\begin{array}{l}0.003 \\
(0.036)\end{array}$ & $\begin{array}{l}0.017 \\
(0.033)\end{array}$ & $\begin{array}{l}0.019 \\
(0.132)\end{array}$ & $\begin{array}{l}-0.008 \\
(0.015)\end{array}$ & $\begin{array}{l}-0.011 \\
(0.164)\end{array}$ \\
\hline Elevation (mean) & & & & $\begin{array}{l}0.021 \\
(0.021)\end{array}$ & $\begin{array}{l}0.034^{*} \\
(0.019)\end{array}$ & $\begin{array}{l}0.040 \\
(0.065)\end{array}$ & $\begin{array}{l}0.006 \\
(0.006)\end{array}$ & $\begin{array}{l}0.058 \\
(0.057)\end{array}$ \\
\hline Average Crop Yield (pre-1500CE) (mean) & & & & $\begin{array}{l}0.081 * * \\
(0.040)\end{array}$ & $\begin{array}{l}0.071 \\
(0.044)\end{array}$ & $\begin{array}{l}0.312^{* *} \\
(0.124)\end{array}$ & $\begin{array}{l}0.030 * * \\
(0.013)\end{array}$ & $\begin{array}{l}0.202^{*} \\
(0.103)\end{array}$ \\
\hline Average Crop Yield (pre-1500CE) (std) & & & & $\begin{array}{l}0.060 * * * \\
(0.020)\end{array}$ & $\begin{array}{l}0.051^{* *} \\
(0.021)\end{array}$ & $\begin{array}{l}0.090^{*} \\
(0.050)\end{array}$ & $\begin{array}{l}0.007 \\
(0.007)\end{array}$ & $\begin{array}{l}0.093 \\
(0.056)\end{array}$ \\
\hline Precipitation (mm/month) (mean) & & & & & $\begin{array}{l}0.060^{*} \\
(0.035)\end{array}$ & $\begin{array}{l}0.160 \\
(0.100)\end{array}$ & $\begin{array}{l}0.016 \\
(0.013)\end{array}$ & $\begin{array}{l}0.126 \\
(0.089)\end{array}$ \\
\hline Temperature (Daily Mean) (mean) & & & & & $\begin{array}{l}0.047^{* *} \\
(0.021)\end{array}$ & $\begin{array}{l}0.088^{*} \\
(0.052)\end{array}$ & $\begin{array}{l}0.008 \\
(0.006)\end{array}$ & $\begin{array}{l}0.065 \\
(0.047)\end{array}$ \\
\hline Precipitation (mm/month) (std) & & & & & $\begin{array}{l}0.054^{* * *} \\
(0.014)\end{array}$ & $\begin{array}{l}0.127^{* *} \\
(0.059)\end{array}$ & $\begin{array}{l}0.016^{* *} \\
(0.007)\end{array}$ & $\begin{array}{l}0.118^{* *} \\
(0.052)\end{array}$ \\
\hline Temperature (Daily Mean) (std) & & & & & $\begin{array}{l}-0.002 \\
(0.008)\end{array}$ & $\begin{array}{l}-0.012 \\
(0.027)\end{array}$ & $\begin{array}{l}-0.000 \\
(0.003)\end{array}$ & $\begin{array}{l}0.002 \\
(0.027)\end{array}$ \\
\hline Country FE & No & Yes & Yes & Yes & Yes & Yes & Yes & Yes \\
\hline Ethnic FE & No & No & Yes & Yes & Yes & Yes & Yes & Yes \\
\hline Adjusted- $R^{2}$ & 0.07 & 0.22 & 0.37 & 0.38 & 0.39 & 0.53 & 0.53 & 0.52 \\
\hline Observations & 4070 & 4070 & 4070 & 4070 & 4070 & 4070 & 4070 & 4070 \\
\hline
\end{tabular}

Notes: Heteroskedasticity robust standard error estimates clustered at the country-level are reported in parentheses; denotes statistical significance at the $1 \%$ level, at the $5 \%$ level, and at the $10 \%$ level, all for two-sided hypothesis tests. 
Table F.2: Historical Ethnic Borders and Conflict (OLS)

\begin{tabular}{|c|c|c|c|}
\hline & \multicolumn{3}{|c|}{ Conflict Intensity } \\
\hline & Events & Years & Fatalities \\
\hline & (1) & $(2)$ & (3) \\
\hline \multirow[t]{2}{*}{ Presence of Ethnic Border } & $0.274^{* * *}$ & $0.027^{* * *}$ & $0.196^{* *}$ \\
\hline & $(0.078)$ & $(0.009)$ & $(0.094)$ \\
\hline Country FE & Yes & Yes & Yes \\
\hline Ethnic FE & Yes & Yes & Yes \\
\hline Main Controls & Yes & Yes & Yes \\
\hline Adjusted- $R^{2}$ & 0.53 & 0.53 & 0.52 \\
\hline Observations & 4070 & 4070 & 4070 \\
\hline
\end{tabular}

Notes: Heteroskedasticity robust standard error estimates clustered at the country-level are reported in parentheses; $* * *$ denotes statistical significance at the $1 \%$ level, ${ }^{* *}$ at the $5 \%$ level, and * at the $10 \%$ level, all for two-sided hypothesis tests. Main Controls refer to the sets of Geographic and Climatic controls described in Table 1.

Table F.3: Historical Ethnic Borders and Conflict (OLS)

\begin{tabular}{llcc}
\hline \hline & \multicolumn{3}{c}{ Prevalence of Conflict } \\
\cline { 2 - 3 } & \multicolumn{1}{c}{$(1)$} & $(2)$ & $(3)$ \\
\hline Presence of Ethnic Border & $0.125^{* * *}$ & & \\
Length of Ethnic Borders (Logs) & $(0.027)$ & $0.035^{* * *}$ & \\
& & $(0.006)$ & $0.147^{* * *}$ \\
Number of Ethnic Borders (Logs) & & & $(0.035)$ \\
& & & Yes \\
Country FE & Yes & Yes & Yes \\
Ethnic FE & Yes & Yes & Yes \\
Main Controls & Yes & Yes & 0.39 \\
Adjusted- $R^{2}$ & 0.39 & 0.39 & 4070 \\
Observations & 4070 & 4070 & \\
\hline
\end{tabular}

Notes: Heteroskedasticity robust standard error estimates clustered at the country-level are reported in parentheses; $* * *$ denotes statistical significance at the $1 \%$ level, $* *$ at the $5 \%$ level, and $*$ at the $10 \%$ level, all for two-sided hypothesis tests. Main Controls refer to the sets of Geographic and Climatic controls described in Table 1. 
Table F.4: Murdock's Ethnic Borders and Voronoi Ethnic Borders Instrumental Variable Analysis (First-Stage)

\begin{tabular}{|c|c|c|c|c|c|}
\hline & \multicolumn{5}{|c|}{ Presence of Ethnic Border } \\
\hline & (1) & $(2)$ & $(3)$ & $(4)$ & $(5)$ \\
\hline Presence of Voronoi Border & $\begin{array}{l}0.418^{* * *} \\
(0.022)\end{array}$ & $\begin{array}{l}0.367^{* * *} \\
(0.026)\end{array}$ & $\begin{array}{l}0.193^{* * *} \\
(0.025)\end{array}$ & $\begin{array}{l}0.171^{* * *} \\
(0.023)\end{array}$ & $\begin{array}{l}0.165^{* * *} \\
(0.023)\end{array}$ \\
\hline Absolute Latitude & & & & $\begin{array}{l}-0.031 \\
(0.041)\end{array}$ & $\begin{array}{l}-0.013 \\
(0.051)\end{array}$ \\
\hline Longitude & & & & $\begin{array}{l}0.051 \\
(0.062)\end{array}$ & $\begin{array}{l}0.038 \\
(0.065)\end{array}$ \\
\hline Elevation (mean) & & & & $\begin{array}{l}-0.142^{* * *} \\
(0.019)\end{array}$ & $\begin{array}{l}-0.154^{* * *} \\
(0.017)\end{array}$ \\
\hline Average Crop Yield (pre-1500CE) (mean) & & & & $\begin{array}{l}0.144^{* * *} \\
(0.020)\end{array}$ & $\begin{array}{l}0.105^{* * *} \\
(0.021)\end{array}$ \\
\hline Average Crop Yield (pre-1500CE) (std) & & & & $\begin{array}{l}0.029 * * \\
(0.014)\end{array}$ & $\begin{array}{l}0.015 \\
(0.015)\end{array}$ \\
\hline Precipitation (mm/month) (mean) & & & & & $\begin{array}{l}0.135^{* * *} \\
(0.047)\end{array}$ \\
\hline Temperature (Daily Mean) (mean) & & & & & $\begin{array}{l}-0.053^{* *} \\
(0.023)\end{array}$ \\
\hline Precipitation (mm/month) (std) & & & & & $\begin{array}{l}0.015 \\
(0.014)\end{array}$ \\
\hline Temperature (Daily Mean) (std) & & & & & $\begin{array}{l}0.033^{* * *} \\
(0.012)\end{array}$ \\
\hline Country FE & No & Yes & Yes & Yes & Yes \\
\hline Ethnic FE & No & No & Yes & Yes & Yes \\
\hline Adjusted- $R^{2}$ & 0.17 & 0.20 & 0.56 & 0.58 & 0.59 \\
\hline Observations & 4070 & 4070 & 4070 & 4070 & 4070 \\
\hline
\end{tabular}

Notes: Heteroskedasticity robust standard error estimates clustered at the country-level are reported in parentheses; $* * *$ denotes statistical significance at the $1 \%$ level, $* *$ at the $5 \%$ level, and * at the $10 \%$ level, all for two-sided hypothesis tests. 
Table F.5: Historical Ethnic Borders and Conflict (IV)

\begin{tabular}{|c|c|c|c|c|c|c|c|}
\hline & \multicolumn{7}{|c|}{ Conflict } \\
\hline & \multirow{2}{*}{\multicolumn{2}{|c|}{$\begin{array}{c}\text { Prevalence } \\
\text { Presence }\end{array}$}} & \multicolumn{3}{|c|}{ Intensity } & \multicolumn{2}{|r|}{ Onset } \\
\hline & & & \multirow{2}{*}{$\frac{\text { Events }}{(3)}$} & \multirow{2}{*}{$\frac{\text { Years }}{(4)}$} & \multirow{2}{*}{$\frac{\text { Fatalities }}{(5)}$} & \multirow{2}{*}{$\frac{\text { Onset }}{(6)}$} & \multirow{2}{*}{$\frac{\text { Number of onsets }}{(7)}$} \\
\hline & $(1)$ & $(2)$ & & & & & \\
\hline Presence of Ethnic Border & $\begin{array}{l}0.561^{* * *} \\
(0.095)\end{array}$ & $\begin{array}{l}0.571^{* * *} \\
(0.103)\end{array}$ & $\begin{array}{l}1.160 * * * \\
(0.244)\end{array}$ & $\begin{array}{l}0.125^{* * *} \\
(0.028)\end{array}$ & $\begin{array}{l}0.959 * * * \\
(0.269)\end{array}$ & $\begin{array}{l}0.199 * * * \\
(0.057)\end{array}$ & $\begin{array}{l}0.170 * * * \\
(0.054)\end{array}$ \\
\hline Country FE & Yes & Yes & Yes & Yes & Yes & Yes & Yes \\
\hline Ethnic FE & Yes & Yes & Yes & Yes & Yes & Yes & Yes \\
\hline Main Controls & No & Yes & Yes & Yes & Yes & Yes & Yes \\
\hline First-stage F-statistic & 59.01 & 52.15 & 52.15 & 52.15 & 52.15 & 52.15 & 52.15 \\
\hline Mean Prevalence & 0.41 & 0.41 & 0.84 & 0.08 & 0.76 & 0.08 & 0.08 \\
\hline Adjusted- $R^{2}$ & 0.30 & 0.31 & 0.49 & 0.49 & 0.50 & 0.27 & 0.34 \\
\hline Observations & 4070 & 4070 & 4070 & 4070 & 4070 & 4070 & 4070 \\
\hline
\end{tabular}

Notes: Heteroskedasticity robust standard error estimates clustered at the country-level are reported in parentheses; ${ }^{* * *}$ denotes statistical significance at the $1 \%$ level, $* *$ at the $5 \%$ level, and ${ }^{*}$ at the $10 \%$ level, all for two-sided hypothesis tests. 
F.2 ACLED Dataset $25 \times 25$

Table F.6: Historical Ethnic Borders and Conflict (OLS)

\begin{tabular}{|c|c|c|c|c|c|c|c|c|}
\hline & \multicolumn{8}{|c|}{ Conflict } \\
\hline & \multicolumn{5}{|c|}{ Prevalence } & \multicolumn{3}{|c|}{ Intensity } \\
\hline & \multicolumn{5}{|c|}{ Presence } & \multirow{2}{*}{$\frac{\text { Events }}{(6)}$} & \multirow{2}{*}{$\frac{\text { Years }}{(7)}$} & \multirow{2}{*}{$\frac{\text { Fatalities }}{(8)}$} \\
\hline & (1) & $(2)$ & $(3)$ & $(4)$ & $(5)$ & & & \\
\hline Presence of Ethnic Border & $\begin{array}{l}0.056^{* * *} \\
(0.013)\end{array}$ & $\begin{array}{l}0.035^{* * *} \\
(0.006)\end{array}$ & $\begin{array}{l}0.052^{* * *} \\
(0.010)\end{array}$ & $\begin{array}{l}0.050^{* * *} \\
(0.009)\end{array}$ & $\begin{array}{l}0.043^{* * *} \\
(0.008)\end{array}$ & $\begin{array}{l}0.090^{* * *} \\
(0.017)\end{array}$ & $\begin{array}{l}0.009^{* * *} \\
(0.002)\end{array}$ & $\begin{array}{l}0.047^{* * *} \\
(0.012)\end{array}$ \\
\hline Absolute Latitude & & & & $\begin{array}{l}0.014 \\
(0.016)\end{array}$ & $\begin{array}{l}0.027 \\
(0.018)\end{array}$ & $\begin{array}{l}0.066^{*} \\
(0.036)\end{array}$ & $\begin{array}{l}0.005 \\
(0.003)\end{array}$ & $\begin{array}{l}-0.001 \\
(0.024)\end{array}$ \\
\hline Longitude & & & & $\begin{array}{l}0.007 \\
(0.014)\end{array}$ & $\begin{array}{l}0.010 \\
(0.014)\end{array}$ & $\begin{array}{l}0.014 \\
(0.024)\end{array}$ & $\begin{array}{l}0.001 \\
(0.002)\end{array}$ & $\begin{array}{l}0.013 \\
(0.024)\end{array}$ \\
\hline Elevation (mean) & & & & $\begin{array}{l}0.000 \\
(0.007)\end{array}$ & $\begin{array}{l}-0.007 \\
(0.007)\end{array}$ & $\begin{array}{l}-0.015 \\
(0.013)\end{array}$ & $\begin{array}{l}-0.001 \\
(0.001)\end{array}$ & $\begin{array}{l}-0.006 \\
(0.009)\end{array}$ \\
\hline Average Crop Yield (pre-1500CE) (mean) & & & & $\begin{array}{l}0.039 * * * \\
(0.009)\end{array}$ & $\begin{array}{l}0.027^{* * *} \\
(0.008)\end{array}$ & $\begin{array}{l}0.048^{* * *} \\
(0.016)\end{array}$ & $\begin{array}{l}0.004^{* *} \\
(0.002)\end{array}$ & $\begin{array}{l}0.028^{* *} \\
(0.014)\end{array}$ \\
\hline Average Crop Yield (pre-1500CE) (std) & & & & $\begin{array}{l}0.010^{* *} \\
(0.004)\end{array}$ & $\begin{array}{l}0.010^{* *} \\
(0.004)\end{array}$ & $\begin{array}{l}0.015^{*} \\
(0.007)\end{array}$ & $\begin{array}{l}0.001 \\
(0.001)\end{array}$ & $\begin{array}{l}0.015^{*} \\
(0.008)\end{array}$ \\
\hline Precipitation (mm/month) (mean) & & & & & $\begin{array}{l}0.039^{* * *} \\
(0.014)\end{array}$ & $\begin{array}{l}0.069 * * \\
(0.026)\end{array}$ & $\begin{array}{l}0.006 * * \\
(0.003)\end{array}$ & $\begin{array}{l}0.027 \\
(0.016)\end{array}$ \\
\hline Temperature (Daily Mean) (mean) & & & & & $\begin{array}{l}-0.015^{*} \\
(0.008)\end{array}$ & $\begin{array}{c}-0.026^{*} \\
(0.015)\end{array}$ & $\begin{array}{l}-0.003^{*} \\
(0.002)\end{array}$ & $\begin{array}{l}-0.019 * \\
(0.011)\end{array}$ \\
\hline Precipitation (mm/month) (std) & & & & & $\begin{array}{l}0.010^{* * *} \\
(0.002)\end{array}$ & $\begin{array}{l}0.013^{* *} \\
(0.006)\end{array}$ & $\begin{array}{l}0.002^{* *} \\
(0.001)\end{array}$ & $\begin{array}{l}0.006 \\
(0.006)\end{array}$ \\
\hline Temperature (Daily Mean) (std) & & & & & $\begin{array}{l}-0.003 \\
(0.002)\end{array}$ & $\begin{array}{l}-0.009^{* *} \\
(0.004)\end{array}$ & $\begin{array}{c}-0.001^{*} \\
(0.000)\end{array}$ & $\begin{array}{l}-0.005 \\
(0.004)\end{array}$ \\
\hline Country FE & No & Yes & Yes & Yes & Yes & Yes & Yes & Yes \\
\hline Ethnic FE & No & No & Yes & Yes & Yes & Yes & Yes & Yes \\
\hline Adjusted- $R^{2}$ & 0.01 & 0.11 & 0.20 & 0.21 & 0.21 & 0.21 & 0.19 & 0.17 \\
\hline Observations & 51972 & 51972 & 51972 & 51972 & 51972 & 51972 & 51972 & 51972 \\
\hline
\end{tabular}

Notes: Heteroskedasticity robust standard error estimates clustered at the country-level are reported in parentheses; denotes statistical significance at the $1 \%$ level, at the $5 \%$ level, and at the $10 \%$ level, all for two-sided hypothesis tests. 
Table F.7: Historical Ethnic Borders and Conflict (OLS)

\begin{tabular}{|c|c|c|c|}
\hline & \multicolumn{3}{|c|}{ Conflict Intensity } \\
\hline & Events & Years & Fatalities \\
\hline & (1) & $(2)$ & $(3)$ \\
\hline Presence of Ethnic Border & $\begin{array}{l}0.090 * * * \\
(0.017)\end{array}$ & $\begin{array}{l}0.009^{* * *} \\
(0.002)\end{array}$ & $\begin{array}{l}0.047^{* * *} \\
(0.012)\end{array}$ \\
\hline Country FE & Yes & Yes & Yes \\
\hline Ethnic FE & Yes & Yes & Yes \\
\hline Main Controls & Yes & Yes & Yes \\
\hline Adjusted- $R^{2}$ & 0.21 & 0.19 & 0.17 \\
\hline Observations & 51972 & 51972 & 51972 \\
\hline
\end{tabular}

Notes: Heteroskedasticity robust standard error estimates clustered at the country-level are reported in parentheses; $* * *$ denotes statistical significance at the $1 \%$ level, $* *$ at the $5 \%$ level, and * at the $10 \%$ level, all for two-sided hypothesis tests.

Table F.8: Historical Ethnic Borders and Conflict (OLS)

\begin{tabular}{llll}
\hline \hline & \multicolumn{3}{c}{ Prevalence of Conflict } \\
\cline { 2 - 4 } & \multicolumn{1}{c}{$(1)$} & $(2)$ & $(3)$ \\
\hline Presence of Ethnic Border & $0.043^{* * *}$ & & \\
Length of Ethnic Borders (Logs) & & & \\
& & $0.008)$ & \\
Number of Ethnic Borders (Logs) & & $(0.002)$ & \\
& & & $0.063^{* * * *}$ \\
Country FE & Yes & Yes & $(0.014)$ \\
Ethnic FE & Yes & Yes & Yes \\
Main Controls & Yes & Yes & Yes \\
Adjusted- $R^{2}$ & 0.21 & 0.21 & 0.21 \\
Observations & 51972 & 51972 & 51972 \\
\hline
\end{tabular}

Notes: Heteroskedasticity robust standard error estimates clustered at the country-level are reported in parentheses; ${ }^{* * *}$ denotes statistical significance at the $1 \%$ level, ${ }^{* *}$ at the $5 \%$ level, and * at the $10 \%$ level, all for two-sided hypothesis tests. 
Table F.9: Murdock's Ethnic Borders and Voronoi Ethnic Borders Instrumental Variable Analysis (First-Stage)

\begin{tabular}{|c|c|c|c|c|c|}
\hline & \multicolumn{5}{|c|}{ Presence of Ethnic Border } \\
\hline & (1) & $(2)$ & $(3)$ & $(4)$ & $(5)$ \\
\hline Presence of Voronoi Border & $\begin{array}{l}0.238^{* * *} \\
(0.016)\end{array}$ & $\begin{array}{l}0.200^{* * *} \\
(0.015)\end{array}$ & $\begin{array}{l}0.100^{* * *} \\
(0.018)\end{array}$ & $\begin{array}{l}0.092^{* * *} \\
(0.016)\end{array}$ & $\begin{array}{l}0.090 * * * \\
(0.016)\end{array}$ \\
\hline Absolute Latitude & & & & $\begin{array}{l}0.003 \\
(0.033)\end{array}$ & $\begin{array}{l}-0.009 \\
(0.042)\end{array}$ \\
\hline Longitude & & & & $\begin{array}{l}0.071 \\
(0.044)\end{array}$ & $\begin{array}{l}0.069 \\
(0.047)\end{array}$ \\
\hline Elevation (mean) & & & & $\begin{array}{l}-0.085^{* * *} \\
(0.012)\end{array}$ & $\begin{array}{l}-0.113^{* * *} \\
(0.011)\end{array}$ \\
\hline Average Crop Yield (pre-1500CE) (mean) & & & & $\begin{array}{l}0.056^{* * *} \\
(0.012)\end{array}$ & $\begin{array}{l}0.030 * * \\
(0.013)\end{array}$ \\
\hline Average Crop Yield (pre-1500CE) (std) & & & & $\begin{array}{l}0.009^{*} \\
(0.005)\end{array}$ & $\begin{array}{l}0.007 \\
(0.005)\end{array}$ \\
\hline Precipitation (mm/month) (mean) & & & & & $\begin{array}{l}0.068 * * \\
(0.031)\end{array}$ \\
\hline Temperature (Daily Mean) (mean) & & & & & $\begin{array}{l}-0.075^{* * *} \\
(0.010)\end{array}$ \\
\hline Precipitation (mm/month) (std) & & & & & $\begin{array}{l}0.001 \\
(0.003)\end{array}$ \\
\hline Temperature (Daily Mean) (std) & & & & & $\begin{array}{l}0.009 * * \\
(0.004)\end{array}$ \\
\hline Country FE & No & Yes & Yes & Yes & Yes \\
\hline Ethnic FE & No & No & Yes & Yes & Yes \\
\hline Adjusted- $R^{2}$ & 0.05 & 0.09 & 0.75 & 0.76 & 0.77 \\
\hline Observations & 51972 & 51972 & 51972 & 51972 & 51972 \\
\hline
\end{tabular}

Notes: Heteroskedasticity robust standard error estimates clustered at the country-level are reported in parentheses; $* * *$ denotes statistical significance at the $1 \%$ level, $* *$ at the $5 \%$ level, and * at the $10 \%$ level, all for two-sided hypothesis tests. 
Table F.10: Historical Ethnic Borders and Conflict (IV)

\begin{tabular}{|c|c|c|c|c|c|c|c|}
\hline & \multicolumn{7}{|c|}{ Conflict } \\
\hline & \multirow{2}{*}{\multicolumn{2}{|c|}{$\begin{array}{c}\text { Prevalence } \\
\text { Presence }\end{array}$}} & \multicolumn{3}{|c|}{ Intensity } & \multicolumn{2}{|r|}{ Onset } \\
\hline & & & \multirow{2}{*}{$\frac{\text { Events }}{(3)}$} & \multirow{2}{*}{$\frac{\text { Years }}{(4)}$} & \multirow{2}{*}{$\frac{\text { Fatalities }}{(5)}$} & \multirow{2}{*}{$\frac{\text { Onset }}{(6)}$} & \multirow{2}{*}{$\frac{\text { Number of onsets }}{(7)}$} \\
\hline & (1) & $(2)$ & & & & & \\
\hline Presence of Ethnic Border & $\begin{array}{l}0.186^{* * *} \\
(0.030)\end{array}$ & $\begin{array}{l}0.183^{* * *} \\
(0.029)\end{array}$ & $\begin{array}{l}0.308^{* * *} \\
(0.056)\end{array}$ & $\begin{array}{l}0.030^{* * *} \\
(0.006)\end{array}$ & $\begin{array}{l}0.254^{* * *} \\
(0.072)\end{array}$ & $\begin{array}{l}0.024^{* *} \\
(0.011)\end{array}$ & $\begin{array}{l}0.023^{* *} \\
(0.011)\end{array}$ \\
\hline Country FE & Yes & Yes & Yes & Yes & Yes & Yes & Yes \\
\hline Ethnic FE & Yes & Yes & Yes & Yes & Yes & Yes & Yes \\
\hline Main Controls & No & Yes & Yes & Yes & Yes & Yes & Yes \\
\hline First-stage F-statistic & 31.20 & 32.98 & 32.98 & 32.98 & 32.98 & 32.98 & 32.98 \\
\hline Mean Prevalence & 0.09 & 0.09 & 0.13 & 0.01 & 0.11 & 0.01 & 0.01 \\
\hline Adjusted- $R^{2}$ & 0.19 & 0.20 & 0.20 & 0.18 & 0.17 & 0.08 & 0.08 \\
\hline Observations & 51972 & 51972 & 51972 & 51972 & 51972 & 51972 & 51972 \\
\hline
\end{tabular}

Notes: Heteroskedasticity robust standard error estimates clustered at the country-level are reported in parentheses; ${ }^{* * *}$ denotes statistical significance at the $1 \%$ level, $* *$ at the $5 \%$ level, and ${ }^{*}$ at the $10 \%$ level, all for two-sided hypothesis tests. 
F.3 ACLED Dataset $10 \times 10$

Table F.11: Historical Ethnic Borders and Conflict (OLS)

\begin{tabular}{|c|c|c|c|c|c|c|c|c|}
\hline & \multicolumn{8}{|c|}{ Conflict } \\
\hline & \multicolumn{5}{|c|}{ Prevalence } & \multicolumn{3}{|c|}{ Intensity } \\
\hline & \multicolumn{5}{|c|}{ Presence } & \multirow{2}{*}{$\frac{\text { Events }}{(6)}$} & \multirow{2}{*}{$\frac{\text { Years }}{(7)}$} & \multirow{2}{*}{$\frac{\text { Fatalities }}{(8)}$} \\
\hline & $(1)$ & $(2)$ & $(3)$ & $(4)$ & $(5)$ & & & \\
\hline Presence of Ethnic Border & $\begin{array}{l}0.016^{* * *} \\
(0.003)\end{array}$ & $\begin{array}{l}0.011^{* * *} \\
(0.002)\end{array}$ & $\begin{array}{l}0.023^{* * *} \\
(0.005)\end{array}$ & $\begin{array}{l}0.022^{* * *} \\
(0.004)\end{array}$ & $\begin{array}{l}0.020^{* * *} \\
(0.004)\end{array}$ & $\begin{array}{l}0.042^{* * *} \\
(0.009)\end{array}$ & $\begin{array}{l}0.004^{* * *} \\
(0.001)\end{array}$ & $\begin{array}{l}0.019 * * * \\
(0.007)\end{array}$ \\
\hline Absolute Latitude & & & & $\begin{array}{l}0.006 \\
(0.005)\end{array}$ & $\begin{array}{l}0.009 \\
(0.006)\end{array}$ & $\begin{array}{l}0.017^{*} \\
(0.009)\end{array}$ & $\begin{array}{l}0.001 \\
(0.001)\end{array}$ & $\begin{array}{l}0.000 \\
(0.006)\end{array}$ \\
\hline Longitude & & & & $\begin{array}{l}0.000 \\
(0.003)\end{array}$ & $\begin{array}{l}0.001 \\
(0.004)\end{array}$ & $\begin{array}{l}0.001 \\
(0.005)\end{array}$ & $\begin{array}{l}0.000 \\
(0.000)\end{array}$ & $\begin{array}{l}0.001 \\
(0.006)\end{array}$ \\
\hline Elevation (mean) & & & & $\begin{array}{l}-0.002 \\
(0.002)\end{array}$ & $\begin{array}{l}-0.005^{* *} \\
(0.002)\end{array}$ & $\begin{array}{c}-0.007^{*} \\
(0.004)\end{array}$ & $\begin{array}{l}-0.001^{*} \\
(0.000)\end{array}$ & $\begin{array}{l}-0.004^{*} \\
(0.002)\end{array}$ \\
\hline Average Crop Yield (pre-1500CE) (mean) & & & & $\begin{array}{l}0.011^{* * *} \\
(0.003)\end{array}$ & $\begin{array}{l}0.008^{* * *} \\
(0.002)\end{array}$ & $\begin{array}{l}0.012^{* *} \\
(0.005)\end{array}$ & $\begin{array}{l}0.001^{* *} \\
(0.000)\end{array}$ & $\begin{array}{l}0.006^{*} \\
(0.003)\end{array}$ \\
\hline Average Crop Yield (pre-1500CE) (std) & & & & $\begin{array}{l}0.001 \\
(0.001)\end{array}$ & $\begin{array}{l}0.001 \\
(0.001)\end{array}$ & $\begin{array}{l}0.002 \\
(0.001)\end{array}$ & $\begin{array}{l}0.000 \\
(0.000)\end{array}$ & $\begin{array}{l}0.002 \\
(0.002)\end{array}$ \\
\hline Precipitation (mm/month) (mean) & & & & & $\begin{array}{l}0.012^{* * *} \\
(0.004)\end{array}$ & $\begin{array}{l}0.019 * * * \\
(0.006)\end{array}$ & $\begin{array}{l}0.002^{* * *} \\
(0.001)\end{array}$ & $\begin{array}{l}0.008^{*} \\
(0.004)\end{array}$ \\
\hline Temperature (Daily Mean) (mean) & & & & & $\begin{array}{l}-0.007 * * \\
(0.003)\end{array}$ & $\begin{array}{l}-0.008^{*} \\
(0.004)\end{array}$ & $\begin{array}{l}-0.001^{*} \\
(0.000)\end{array}$ & $\begin{array}{l}-0.006^{* *} \\
(0.003)\end{array}$ \\
\hline Precipitation (mm/month) (std) & & & & & $\begin{array}{l}0.002^{* * *} \\
(0.001)\end{array}$ & $\begin{array}{l}0.003^{* * *} \\
(0.001)\end{array}$ & $\begin{array}{l}0.000^{* * *} \\
(0.000)\end{array}$ & $\begin{array}{l}0.001 \\
(0.001)\end{array}$ \\
\hline Temperature (Daily Mean) (std) & & & & & $\begin{array}{c}-0.001^{*} \\
(0.000)\end{array}$ & $\begin{array}{c}-0.002^{*} \\
(0.001)\end{array}$ & $\begin{array}{c}-0.000^{*} \\
(0.000)\end{array}$ & $\begin{array}{l}-0.001 \\
(0.001)\end{array}$ \\
\hline Country FE & No & Yes & Yes & Yes & Yes & Yes & Yes & Yes \\
\hline Ethnic FE & No & No & Yes & Yes & Yes & Yes & Yes & Yes \\
\hline Adjusted- $R^{2}$ & 0.00 & 0.04 & 0.08 & 0.08 & 0.08 & 0.06 & 0.06 & 0.05 \\
\hline Observations & 308122 & 308122 & 308122 & 308122 & 308122 & 308122 & 308122 & 308122 \\
\hline
\end{tabular}

Notes: Heteroskedasticity robust standard error estimates clustered at the country-level are reported in parentheses; denotes statistical significance at the $1 \%$ level, at the $5 \%$ level, and at the $10 \%$ level, all for two-sided hypothesis tests. 
Table F.12: Historical Ethnic Borders and Conflict (OLS)

\begin{tabular}{|c|c|c|c|}
\hline & \multicolumn{3}{|c|}{ Conflict Intensity } \\
\hline & Events & Years & Fatalities \\
\hline & $(1)$ & $(2)$ & $(3)$ \\
\hline Presence of Ethnic Border & $\begin{array}{l}0.042^{* * *} \\
(0.009)\end{array}$ & $\begin{array}{l}0.004^{* * *} \\
(0.001)\end{array}$ & $\begin{array}{l}0.019^{* * *} \\
(0.007)\end{array}$ \\
\hline Country FE & Yes & Yes & Yes \\
\hline Ethnic FE & Yes & Yes & Yes \\
\hline Main Controls & Yes & Yes & Yes \\
\hline Adjusted- $R^{2}$ & 0.06 & 0.06 & 0.05 \\
\hline Observations & 308122 & 308122 & 308122 \\
\hline
\end{tabular}

Notes: Heteroskedasticity robust standard error estimates clustered at the country-level are reported in parentheses; $* * *$ denotes statistical significance at the $1 \%$ level, ${ }^{* *}$ at the $5 \%$ level, and * at the $10 \%$ level, all for two-sided hypothesis tests.

Table F.13: Historical Ethnic Borders and Conflict (OLS)

\begin{tabular}{|c|c|c|c|}
\hline & \multicolumn{3}{|c|}{ Prevalence of Conflict } \\
\hline & $(1)$ & $(2)$ & $(3)$ \\
\hline Presence of Ethnic Border & $\begin{array}{l}0.020 * * * \\
(0.004)\end{array}$ & & \\
\hline Length of Ethnic Borders (Logs) & & $\begin{array}{l}0.006 * * * \\
(0.001)\end{array}$ & \\
\hline Number of Ethnic Borders (Logs) & & & $\begin{array}{l}0.026^{* * *} \\
(0.007)\end{array}$ \\
\hline Country FE & Yes & Yes & Yes \\
\hline Ethnic FE & Yes & Yes & Yes \\
\hline Main Controls & Yes & Yes & Yes \\
\hline Adjusted- $R^{2}$ & 0.08 & 0.08 & 0.08 \\
\hline Observations & 308122 & 308122 & 308122 \\
\hline
\end{tabular}

Notes: Heteroskedasticity robust standard error estimates clustered at the country-level are reported in parentheses; ${ }^{* * *}$ denotes statistical significance at the $1 \%$ level, ${ }^{* *}$ at the $5 \%$ level, and * at the $10 \%$ level, all for two-sided hypothesis tests. 
Table F.14: Murdock's Ethnic Borders and Voronoi Ethnic Borders Instrumental Variable Analysis (First-Stage)

\begin{tabular}{|c|c|c|c|c|c|}
\hline & \multicolumn{5}{|c|}{ Presence of Ethnic Border } \\
\hline & (1) & $(2)$ & $(3)$ & $(4)$ & $(5)$ \\
\hline Presence of Voronoi Border & $\begin{array}{l}0.156^{* * *} \\
(0.016)\end{array}$ & $\begin{array}{l}0.137^{* * *} \\
(0.015)\end{array}$ & $\begin{array}{l}0.088^{* * *} \\
(0.017)\end{array}$ & $\begin{array}{l}0.085^{* * *} \\
(0.016)\end{array}$ & $\begin{array}{l}0.084^{* * *} \\
(0.016)\end{array}$ \\
\hline Absolute Latitude & & & & $\begin{array}{l}0.002 \\
(0.038)\end{array}$ & $\begin{array}{l}-0.020 \\
(0.045)\end{array}$ \\
\hline Longitude & & & & $\begin{array}{l}0.070^{*} \\
(0.040)\end{array}$ & $\begin{array}{l}0.066 \\
(0.042)\end{array}$ \\
\hline Elevation (mean) & & & & $\begin{array}{l}-0.039^{* * *} \\
(0.007)\end{array}$ & $\begin{array}{l}-0.060^{* * *} \\
(0.008)\end{array}$ \\
\hline Average Crop Yield (pre-1500CE) (mean) & & & & $\begin{array}{l}0.018^{* * *} \\
(0.006)\end{array}$ & $\begin{array}{l}0.006 \\
(0.008)\end{array}$ \\
\hline Average Crop Yield (pre-1500CE) (std) & & & & $\begin{array}{l}0.001 \\
(0.002)\end{array}$ & $\begin{array}{l}0.000 \\
(0.002)\end{array}$ \\
\hline Precipitation (mm/month) (mean) & & & & & $\begin{array}{l}0.021 \\
(0.023)\end{array}$ \\
\hline Temperature (Daily Mean) (mean) & & & & & $\begin{array}{l}-0.053^{* * *} \\
(0.011)\end{array}$ \\
\hline Precipitation (mm/month) (std) & & & & & $\begin{array}{l}-0.001 \\
(0.001)\end{array}$ \\
\hline Temperature (Daily Mean) (std) & & & & & $\begin{array}{l}0.006^{* * *} \\
(0.002)\end{array}$ \\
\hline Country FE & No & Yes & Yes & Yes & Yes \\
\hline Ethnic FE & No & No & Yes & Yes & Yes \\
\hline Adjusted- $R^{2}$ & 0.02 & 0.04 & 0.78 & 0.79 & 0.79 \\
\hline Observations & 308122 & 308122 & 308122 & 308122 & 308122 \\
\hline
\end{tabular}

Notes: Heteroskedasticity robust standard error estimates clustered at the country-level are reported in parentheses; $* * *$ denotes statistical significance at the $1 \%$ level, $* *$ at the $5 \%$ level, and * at the $10 \%$ level, all for two-sided hypothesis tests. 
Table F.15: Historical Ethnic Borders and Conflict (IV)

\begin{tabular}{|c|c|c|c|c|c|c|c|}
\hline & \multicolumn{7}{|c|}{ Conflict } \\
\hline & \multirow{2}{*}{\multicolumn{2}{|c|}{$\begin{array}{c}\text { Prevalence } \\
\text { Presence }\end{array}$}} & \multicolumn{3}{|c|}{ Intensity } & \multicolumn{2}{|r|}{ Onset } \\
\hline & & & \multirow{2}{*}{$\frac{\text { Events }}{(3)}$} & \multirow{2}{*}{$\frac{\text { Years }}{(4)}$} & \multirow{2}{*}{$\frac{\text { Fatalities }}{(5)}$} & \multirow{2}{*}{$\frac{\text { Onset }}{(6)}$} & \multirow{2}{*}{$\frac{\text { Number of onsets }}{(7)}$} \\
\hline & $(1)$ & $(2)$ & & & & & \\
\hline Presence of Ethnic Border & $\begin{array}{l}0.060 * * * \\
(0.014)\end{array}$ & $\begin{array}{l}0.057^{* * *} \\
(0.014)\end{array}$ & $\begin{array}{l}0.104^{* * *} \\
(0.022)\end{array}$ & $\begin{array}{l}0.009 * * * \\
(0.002)\end{array}$ & $\begin{array}{l}0.054^{* * *} \\
(0.018)\end{array}$ & $\begin{array}{l}0.004 \\
(0.003)\end{array}$ & $\begin{array}{l}0.003 \\
(0.003)\end{array}$ \\
\hline Country FE & Yes & Yes & Yes & Yes & Yes & Yes & Yes \\
\hline Ethnic FE & Yes & Yes & Yes & Yes & Yes & Yes & Yes \\
\hline Main Controls & No & Yes & Yes & Yes & Yes & Yes & Yes \\
\hline First-stage F-statistic & 26.98 & 27.92 & 27.92 & 27.92 & 27.92 & 27.92 & 27.92 \\
\hline Mean Prevalence & 0.02 & 0.02 & 0.03 & 0.00 & 0.02 & 0.00 & 0.00 \\
\hline Adjusted- $R^{2}$ & 0.08 & 0.08 & 0.06 & 0.05 & 0.05 & 0.02 & 0.02 \\
\hline Observations & 308122 & 308122 & 308122 & 308122 & 308122 & 308122 & 308122 \\
\hline
\end{tabular}

Notes: Heteroskedasticity robust standard error estimates clustered at the country-level are reported in parentheses; ${ }^{* * *}$ denotes statistical significance at the $1 \%$ level, ${ }^{* *}$ at the $5 \%$ level, and ${ }^{*}$ at the $10 \%$ level, all for two-sided hypothesis tests. 


\section{G Robustness to Alternative Instrument}

\section{G.1 Human Mobility Index Voronoi}

Table G.1: Historical Ethnic Borders and Conflict (OLS)

\begin{tabular}{llllll}
\hline \hline & \multicolumn{5}{c}{ Prevalence of Conflict } \\
\cline { 2 - 6 } & \multicolumn{1}{c}{$(1)$} & $(2)$ & $(3)$ & $(4)$ & \multicolumn{1}{c}{$(5)$} \\
\hline Presence of Ethnic Border & $0.164^{* * *}$ & $0.112^{* * *}$ & $0.086^{* * *}$ & $0.082^{* * *}$ & $0.073^{* * *}$ \\
& $(0.026)$ & $(0.016)$ & $(0.021)$ & $(0.019)$ & $(0.018)$ \\
\hline Country FE & No & Yes & Yes & Yes & Yes \\
Ethnic FE & No & No & Yes & Yes & Yes \\
Geographic Controls & No & No & No & Yes & Yes \\
Climatic Controls & No & No & No & No & Yes \\
\hline Adjusted- $R^{2}$ & 0.03 & 0.19 & 0.33 & 0.34 & 0.34 \\
Observations & 14078 & 14078 & 14078 & 14078 & 14078 \\
\hline
\end{tabular}

Notes: Heteroskedasticity robust standard error estimates clustered at the country-level are reported in parentheses; denotes statistical significance at the $1 \%$ level, at the $5 \%$ level, and at the $10 \%$ level, all for two-sided hypothesis tests. The set of Geographic Controls includes absolute latitude, longitude, mean elevation, and mean and standard deviation of average crop yield (pre-1500CE). The set of Climatic Controls includes mean and standard deviation for precipitation $(\mathrm{mm} / \mathrm{month})$ and daily mean temperature.

Table G.2: Historical Ethnic Borders and Conflict (OLS)

\begin{tabular}{|c|c|c|c|}
\hline & \multicolumn{3}{|c|}{ Conflict Intensity } \\
\hline & Events & Years & Fatalities \\
\hline & $(1)$ & $(2)$ & $(3)$ \\
\hline Presence of Ethnic Border & $\begin{array}{l}0.191^{* * *} \\
(0.038)\end{array}$ & $\begin{array}{l}0.018^{* * *} \\
(0.003)\end{array}$ & $\begin{array}{l}0.191^{* * *} \\
(0.043)\end{array}$ \\
\hline Country FE & Yes & Yes & Yes \\
\hline Ethnic FE & Yes & Yes & Yes \\
\hline Main Controls & Yes & Yes & Yes \\
\hline Adjusted- $R^{2}$ & 0.40 & 0.39 & 0.36 \\
\hline Observations & 14078 & 14078 & 14078 \\
\hline
\end{tabular}

Notes: Heteroskedasticity robust standard error estimates clustered at the country-level are reported in parentheses; *** denotes statistical significance at the $1 \%$ level, ${ }^{* *}$ at the $5 \%$ level, and * at the $10 \%$ level, all for two-sided hypothesis tests. Main Controls refer to the sets of Geographic and Climatic controls described in Table 1. 
Table G.3: Historical Ethnic Borders and Conflict (OLS)

\begin{tabular}{llll}
\hline \hline & \multicolumn{3}{c}{ Prevalence of Conflict } \\
\cline { 2 - 4 } & \multicolumn{1}{c}{$(1)$} & $(2)$ & $(3)$ \\
\hline Presence of Ethnic Border & $0.073^{* * *}$ & & \\
Length of Ethnic Borders (Logs) & $(0.018)$ & & \\
& & $0.023^{* * *}$ & \\
Number of Ethnic Borders (Logs) & & & $0.004)$ \\
& & & $(0.031)$ \\
\hline Country FE & Yes & Yes & Yes \\
Ethnic FE & Yes & Yes & Yes \\
Main Controls & Yes & Yes & Yes \\
Adjusted- $R^{2}$ & 0.34 & 0.34 & 0.34 \\
Observations & 14078 & 14078 & 14078 \\
\hline
\end{tabular}

Notes: Heteroskedasticity robust standard error estimates clustered at the country-level are reported in parentheses; $* * *$ denotes statistical significance at the $1 \%$ level, $* *$ at the $5 \%$ level, and $*$ at the $10 \%$ level, all for two-sided hypothesis tests. Main Controls refer to the sets of Geographic and Climatic controls described in Table 1.

Table G.4: Murdock's Ethnic Borders and Voronoi Ethnic Borders Instrumental Variable Analysis (First-Stage)

\begin{tabular}{|c|c|c|c|c|c|c|c|c|c|}
\hline & \multicolumn{9}{|c|}{ Ethnic Border } \\
\hline & \multicolumn{3}{|c|}{ Presence } & \multicolumn{3}{|c|}{ Length } & \multicolumn{3}{|c|}{ Number } \\
\hline & $(1)$ & $(2)$ & $(3)$ & $(4)$ & $(5)$ & $(6)$ & $(7)$ & $(8)$ & (9) \\
\hline Presence of Voronoi Border & $\begin{array}{l}0.105^{* * *} \\
(0.017)\end{array}$ & & & $\begin{array}{l}0.451^{* * *} \\
(0.066)\end{array}$ & & & $\begin{array}{l}0.074^{* * *} \\
(0.012)\end{array}$ & & \\
\hline Length of Voronoi Borders (Logs) & & $\begin{array}{l}0.018 * * * \\
(0.003)\end{array}$ & & & $\begin{array}{l}0.094^{* * *} \\
(0.013)\end{array}$ & & & $\begin{array}{l}0.013^{* * *} \\
(0.002)\end{array}$ & \\
\hline Number of Voronoi Borders (Logs) & & & $\begin{array}{l}0.079 * * * \\
(0.014)\end{array}$ & & & $\begin{array}{l}0.365^{* * *} \\
(0.055)\end{array}$ & & & $\begin{array}{l}0.063^{* * *} \\
(0.010)\end{array}$ \\
\hline Country FE & Yes & Yes & Yes & Yes & Yes & Yes & Yes & Yes & Yes \\
\hline Ethnic FE & Yes & Yes & Yes & Yes & Yes & Yes & Yes & Yes & Yes \\
\hline Main Controls & Yes & Yes & Yes & Yes & Yes & Yes & Yes & Yes & Yes \\
\hline Adjusted- $R^{2}$ & 0.70 & 0.70 & 0.70 & 0.74 & 0.74 & 0.74 & 0.89 & 0.88 & 0.88 \\
\hline Observations & 14078 & 14078 & 14078 & 14078 & 14078 & 14078 & 14078 & 14078 & 14078 \\
\hline
\end{tabular}

Notes: Heteroskedasticity robust standard error estimates clustered at the country-level are reported in parentheses; $* * *$ denotes statistical significance at the $1 \%$ level, $* *$ at the $5 \%$ level, and ${ }^{*}$ at the $10 \%$ level, all for two-sided hypothesis tests Main Controls refer to the sets of Geographic and Climatic controls described in Table 1. 
Table G.5: Historical Ethnic Borders and Conflict (IV)

\begin{tabular}{|c|c|c|c|c|c|c|c|}
\hline & \multicolumn{7}{|c|}{ Conflict } \\
\hline & \multicolumn{4}{|c|}{ Prevalence } & \multicolumn{3}{|c|}{ Intensity } \\
\hline & \multicolumn{4}{|c|}{ Presence } & Events & Years & Fatalities \\
\hline & $(1)$ & $(2)$ & $(3)$ & $(4)$ & $(5)$ & $(6)$ & $(7)$ \\
\hline Presence of Ethnic Border & $\begin{array}{l}0.431^{* * *} \\
(0.067)\end{array}$ & $\begin{array}{l}0.313^{* * *} \\
(0.049)\end{array}$ & $\begin{array}{l}0.307 * * * \\
(0.075)\end{array}$ & $\begin{array}{l}0.313^{* * *} \\
(0.077)\end{array}$ & $\begin{array}{l}0.818^{* * *} \\
(0.166)\end{array}$ & $\begin{array}{l}0.071^{* * *} \\
(0.016)\end{array}$ & $\begin{array}{l}0.799 * * * \\
(0.196)\end{array}$ \\
\hline Country FE & No & Yes & Yes & Yes & Yes & Yes & Yes \\
\hline Ethnic FE & No & No & Yes & Yes & Yes & Yes & Yes \\
\hline Main Controls & No & No & No & Yes & Yes & Yes & Yes \\
\hline First-stage F-statistic & 323.01 & 195.88 & 37.67 & 37.29 & 37.29 & 37.29 & 37.29 \\
\hline Adjusted- $R^{2}$ & -0.05 & 0.15 & 0.31 & 0.32 & 0.38 & 0.38 & 0.35 \\
\hline Observations & 14078 & 14078 & 14078 & 14078 & 14078 & 14078 & 14078 \\
\hline
\end{tabular}

Notes: Heteroskedasticity robust standard error estimates clustered at the country-level are reported in parentheses; *** denotes statistical significance at the $1 \%$ level, ** at the $5 \%$ level, and * at the $10 \%$ level, all for two-sided hypothesis tests. Main Controls refer to the sets of Geographic and Climatic controls described in Table 1. 


\section{G.2 Exploiting both Instruments}

Table G.6: Murdock's Ethnic Borders and Voronoi Ethnic Borders Instrumental Variable Analysis (First-Stage)

\begin{tabular}{|c|c|c|c|c|c|c|c|c|c|}
\hline & \multicolumn{9}{|c|}{ Ethnic Border } \\
\hline & \multicolumn{3}{|c|}{ Presence } & \multicolumn{3}{|c|}{ Length } & \multicolumn{3}{|c|}{ Number } \\
\hline & $(1)$ & $(2)$ & $(3)$ & $(4)$ & $(5)$ & $(6)$ & $(7)$ & $(8)$ & $(9)$ \\
\hline Presence of Voronoi Border & $\begin{array}{l}0.046^{* * *} \\
(0.011)\end{array}$ & & & $\begin{array}{l}0.194^{* * *} \\
(0.052)\end{array}$ & & & $\begin{array}{l}0.031^{* * *} \\
(0.007)\end{array}$ & & \\
\hline Length of Voronoi Borders (Logs) & & $\begin{array}{l}-0.004 \\
(0.003)\end{array}$ & & & $\begin{array}{l}-0.008 \\
(0.014)\end{array}$ & & & $\begin{array}{l}-0.005^{*} \\
(0.003)\end{array}$ & \\
\hline Number of Voronoi Borders (Logs) & & & $\begin{array}{l}0.038 * * * \\
(0.011)\end{array}$ & & & $\begin{array}{l}0.197^{* * *} \\
(0.048)\end{array}$ & & & $\begin{array}{l}0.031^{* * *} \\
(0.007)\end{array}$ \\
\hline Presence of HMI Voronoi Border & $\begin{array}{l}0.067 \text { *** } \\
(0.018)\end{array}$ & & & $\begin{array}{l}0.291^{\text {*** }} \\
(0.066)\end{array}$ & & & $\begin{array}{l}0.049^{* * *} \\
(0.010)\end{array}$ & & \\
\hline Length of HMI Voronoi Borders (Logs) & & $\begin{array}{l}0.025^{* * *} \\
(0.006)\end{array}$ & & & $\begin{array}{l}0.116^{* * *} \\
(0.024)\end{array}$ & & & $\begin{array}{l}0.020 * * * \\
(0.004)\end{array}$ & \\
\hline Number of HMI Voronoi Borders (Logs) & & & $\begin{array}{l}0.046^{* * *} \\
(0.016)\end{array}$ & & & $\begin{array}{l}0.191^{* * *} \\
(0.057)\end{array}$ & & & $\begin{array}{l}0.037^{* * *} \\
(0.010)\end{array}$ \\
\hline Country FE & Yes & Yes & Yes & Yes & Yes & Yes & Yes & Yes & Yes \\
\hline Ethnic FE & Yes & Yes & Yes & Yes & Yes & Yes & Yes & Yes & Yes \\
\hline Main Controls & Yes & Yes & Yes & Yes & Yes & Yes & Yes & Yes & Yes \\
\hline Adjusted- $R^{2}$ & 0.71 & 0.70 & 0.70 & 0.74 & 0.74 & 0.74 & 0.89 & 0.88 & 0.88 \\
\hline Observations & 14078 & 14078 & 14078 & 14078 & 14078 & 14078 & 14078 & 14078 & 14078 \\
\hline
\end{tabular}

Notes: Heteroskedasticity robust standard error estimates clustered at the country-level are reported in parentheses; *** denotes statistical significance at the $1 \%$ level, ** at the $5 \%$ level, and * at the $10 \%$ level, all for two-sided hypothesis tests. Main Controls refer to the sets of Geographic and Climatic controls described in Table 1. 
Table G.7: Historical Ethnic Borders and Conflict (IV)

\begin{tabular}{|c|c|c|c|c|c|c|c|}
\hline & \multicolumn{7}{|c|}{ Conflict } \\
\hline & \multicolumn{4}{|c|}{ Prevalence } & \multicolumn{3}{|c|}{ Intensity } \\
\hline & \multicolumn{4}{|c|}{ Presence } & \multirow{2}{*}{$\frac{\text { Events }}{(5)}$} & \multirow{2}{*}{$\frac{\text { Years }}{(6)}$} & \multirow{2}{*}{$\frac{\text { Fatalities }}{(7)}$} \\
\hline & $(1)$ & $(2)$ & $(3)$ & (4) & & & \\
\hline Presence of Ethnic Border & $\begin{array}{l}0.434^{* * *} \\
(0.068)\end{array}$ & $\begin{array}{l}0.317^{* * *} \\
(0.050)\end{array}$ & $\begin{array}{l}0.300^{* * *} \\
(0.074)\end{array}$ & $\begin{array}{l}0.303^{* * *} \\
(0.076)\end{array}$ & $\begin{array}{l}0.785^{* * *} \\
(0.165) \\
\end{array}$ & $\begin{array}{l}0.067^{* * *} \\
(0.016)\end{array}$ & $\begin{array}{l}0.812^{* * *} \\
(0.187)\end{array}$ \\
\hline Country FE & No & Yes & Yes & Yes & Yes & Yes & Yes \\
\hline Ethnic FE & No & No & Yes & Yes & Yes & Yes & Yes \\
\hline Main Controls & No & No & No & Yes & Yes & Yes & Yes \\
\hline First-stage F-statistic & 168.98 & 108.83 & 19.94 & 20.15 & 20.15 & 20.15 & 20.15 \\
\hline Hansen's J-statistic & 0.41 & 0.81 & 0.39 & 0.86 & 1.34 & 1.15 & 0.07 \\
\hline J-stat p-value & 0.52 & 0.37 & 0.53 & 0.35 & 0.25 & 0.28 & 0.79 \\
\hline Adjusted- $R^{2}$ & -0.05 & -0.04 & -0.09 & -0.08 & -0.08 & -0.06 & -0.07 \\
\hline Observations & 14078 & 14078 & 14078 & 14078 & 14078 & 14078 & 14078 \\
\hline
\end{tabular}

Notes: Heteroskedasticity robust standard error estimates clustered at the country-level are reported in parentheses; $* * *$ denotes statistical significance at the $1 \%$ level, $* *$ at the $5 \%$ level, and * at the $10 \%$ level, all for two-sided hypothesis tests. Main Controls refer to the sets of Geographic and Climatic controls described in Table 1. 